CARLA DEGUIRMENDJIAN ROSA CARVALHO

DISTRIBUIÇÃO URBANA DE CARGA: UM ESTUDO COM EMPRESAS QUE ATUAM NA REGIÃO METROPOLITANA DE SÃO PAULO (RMSP) 
CARLA DEGUIRMENDJIAN ROSA CARVALHO

\section{DISTRIBUIÇÃO URBANA DE CARGA: UM ESTUDO COM EMPRESAS QUE ATUAM NA REGIÃO METROPOLITANA DE SÃO PAULO (RMSP)}

Dissertação apresentada à Escola Politécnica da Universidade de São Paulo para obtenção do título de Mestre em Ciências. 
CARLA DEGUIRMENDJIAN ROSA CARVALHO

\title{
DISTRIBUIÇÃO URBANA DE CARGA: UM ESTUDO COM EMPRESAS QUE ATUAM NA REGIÃO METROPOLITANA DE SÃO PAULO (RMSP)
}

\author{
Dissertação apresentada à Escola \\ Politécnica da Universidade de São \\ Paulo para obtenção do título de \\ Mestre em Ciências. \\ Área de concentração: \\ Sistemas Logísticos \\ Orientador: \\ Professor Doutor José Geraldo Vidal \\ Vieira
}

São Paulo 


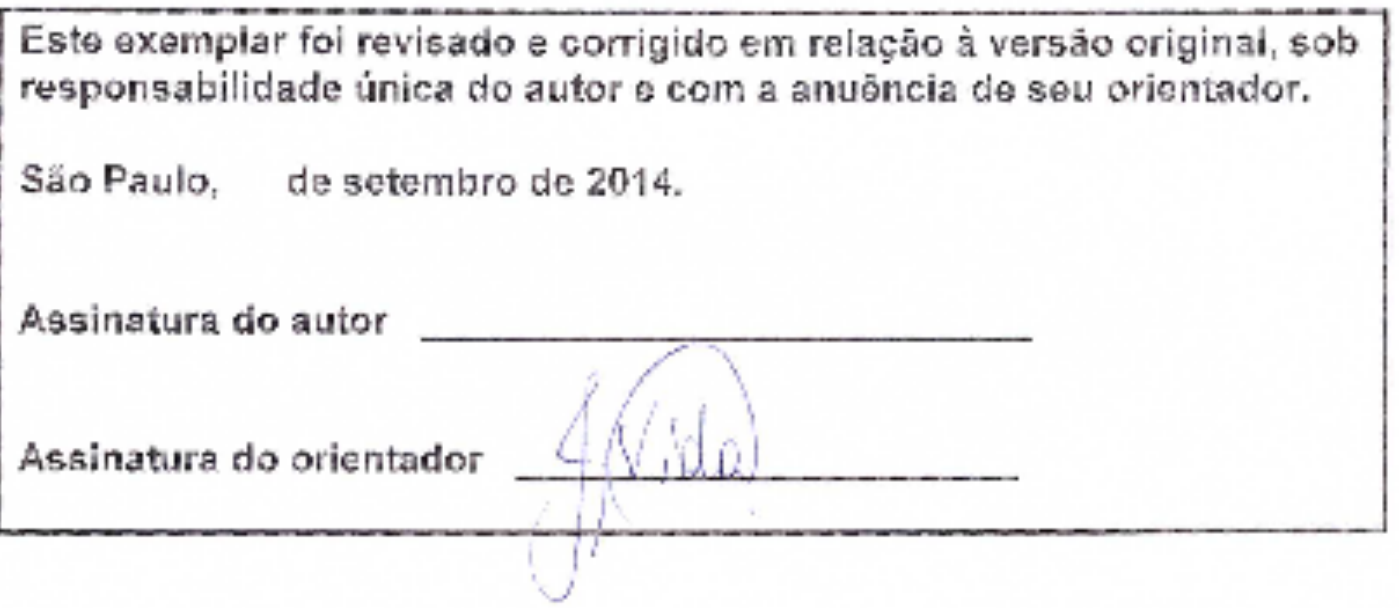

Catalogação-na-publicação

Carvalho, Carla Deguirmendjian Rosa

Distribuiçẫo urbana de carga: um estudo com empresas que atuam na região metropolitana de São Paulo (RMSP) / C.D.R. Carvalho. -- versão corr. -- São Paulo, 2014.

$143 \mathrm{p}$.

Dissertação (Mestrado) - Escola Politécnica da Universidade de São Paulo. Departamento de Engenharia de Transportes. Sistemas Logisticos.

1.Mercadoria (Distribuiçāo) - Säo Paulo (SP) I.Universidade de São Paulo. Escola Politécnica. Departamento de Engenharia de Transportes Il.t. 


\section{DEDICATÓRIA}

Dedico este trabalho aos meus pais Rubens e Claudete e aos amores da minha vida Pedro e Thiago 


\section{AGRADECIMENTOS}

Ao professor José Geraldo Vidal Vieira pela orientação e generosidade durante todo o trabalho.

Aos professores Hugo Yoshizaki e Claudio Barbieri por todos os ensinamentos e oportunidades.

Ao professor Douglas Tacla por suas recomendações e por ter aceitado fazer parte da minha banca.

À Nathalia Zambuzi pelas sugestões e amizade de sempre.

A todos os profissionais das empresas participantes dos estudos de caso que tanto me ajudaram.

À minha família e aos meus amigos pelo apoio incondicional, carinho e acolhimento. À minha mãe, ao meu marido e ao meu filho pela compreensão e paciência ao longo desta jornada. 


\section{RESUMO}

As externalidades negativas geradas pela distribuição urbana de cargas como congestionamentos, poluição e ruídos, são amplamente conhecidas e vivenciadas pela população que vive em grandes centros urbanos. Esses problemas têm sido agravados pelo crescimento da população urbana, pela crise no modelo de mobilidade adotado nas grandes cidades brasileiras e pelo aumento da complexidade do processo de distribuição urbana de carga. Nesse sentido, alguns atributos podem contribuir para a melhoria do desempenho logístico dos agentes participantes na distribuição de carga e outros podem dificultar a sua competitividade A investigação dos atributos de distribuição urbana de carga e dos papéis desses agentes são o ponto de partida deste estudo. A presente dissertação tem o objetivo identificar os atributos de distribuição urbana de carga, levando-se em conta os diferentes pontos de vista dos principais responsáveis pela distribuição de carga na RMSP e que atuam no mercado varejista: Embarcador, Operador Logístico, Transportador e Cliente. Para tanto, foi feita a análise do referencial teórico sobre o tema distribuição urbana de carga, foram desenvolvidos dois estudos de caso em Operadores logísticos que atuam na logística de distribuição de carga na Região Metropolitana de São Paulo. Foi também realizado um levantamento de dados com 119 prestadores de serviços logísticos, Operador logístico e Transportador, obtidas pela aplicação de questionário de pesquisa com esses agentes. Por meio das informações obtidas, verificou-se que os atributos relevantes e unânimes entre os prestadores de serviços logísticos, são: filas e local para carga e descarga, flexibilidade, restrição de circulação por tamanho de veículo, local regulamentado para estacionar veículos de carga, congestionamento e roubo de carga. Adicionalmente, o consumo sazonal e o comprometimento no recebimento são os problemas mais relevantes segundo os Operadores logísticos e Transportadores, respectivamente.

Palavras - chave: Distribuição urbana de carga. Atributos de distribuição de carga. Colaboração logística. Região Metropolitana de São Paulo. 


\section{ABSTRACT}

The negative externalities generated by the urban distribution of cargo, such as traffic jams, pollution and noise, are widely known and experienced by the population living in large urban centers. These problems have been aggravated by the growth in urban population, by the crisis in the mobility model adopted in the large Brazilian cities and by the growth in complexity of the urban cargo distribution process. In this sense, some attributes may contribute to improving the logistic performance of the agents participating in the cargo distribution and others may hinder its competitiveness. The investigation into the urban cargo distribution attributes and of these agents' roles is the starting point of this study. The present thesis aims to analyze the urban cargo distribution attributes, taking into account the different points of view of the major actors in the cargo distribution in the São Paulo Metropolitan Region (SPMR) and acting in the retail market: Shipper, Logistic Operator, Carrier and Client. For this, an analysis of the theoretical referential was performed regarding the theme urban cargo distribution; two case studies were conducted with Logistic Operators acting in the cargo distribution logistics in the São Paulo Metropolitan Region and, lastly, the descriptive measures of the problems faced by Logistic Service Renderers, Logistic Operators and Carriers were analyzed, obtained from the application of a research questionnaire to these agents. From the information obtained, the relevant and unanimous attributes among the logistic service renderers were verified to be: lines and places for loading/ unloading, flexibility, circulation constraints as per the size of the vehicle, regulated place to stop cargo vehicles, traffic jam and cargo theft. Added to these attributes are seasonal consumption and product compromised at receipt, which are considered relevant by Logistic Operators and Carriers, respectively.

Keyword: Urban goods distribution. Urban logistics attribute. Logistics collaboration. São Paulo Metropolitan Region (SPMR). 


\section{LISTA DE FIGURAS}

Figura 1 - Mapa do Estado de São Paulo............................................................... 5

Figura 2 - Mapa da RMSP e Cidade de São Paulo ............................................ 5

Figura 3 - Maiores aglomerações urbana no mundo........................................ 5

Figura 4 - Canais tradicionais de distribuição ................................................ 25

Figura 5 - Atividades- chave no atendimento ao pequeno varejo ......................... 27

Figura 6 - Estratégias de atendimento: canal direto $x$ canal indireto....................... 28

Figura 7 - Esquema da distribuição de carga em megacidades brasileiras .............. 30

Figura 8 - Atividades logísticas na cadeia de suprimentos genérica.......................48

Figura 9 - Elementos de uma cadeia de suprimentos típica do varejo .................... 49

Figura 10 - Indicadores Individuais e da Cadeia de Suprimentos ........................... 50

Figura 11 - Evolução da população - Brasil, Estado de São Paulo, RMSP e

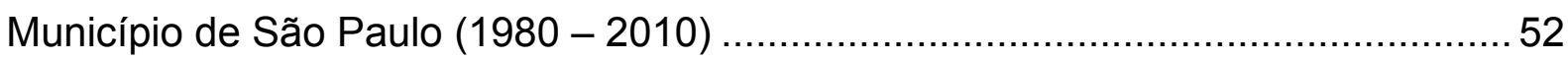

Figura 12 - Taxas de urbanização em 2010 - Estado de São Paulo, RMSP e Município de São Paulo.

Figura 13 - População urbana e rural - Grau de urbanização- Município de São

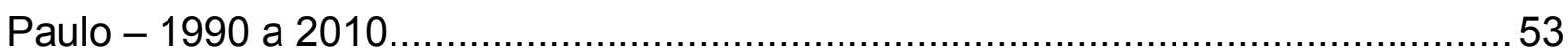

Figura 14 - Mapa das restrições de circulação de veículos de carga........................56

Figura 15 - Síntese das etapas e procedimentos técnicos desta pesquisa..............60

Figura 16 - Abordagem da pesquisa para definição dos atributos ........................ 61

Figura 17 - Estrutura da distribuição de carga na RMSP- empresa A.....................74

Figura 18 - Estrutura da distribuição de carga na RMSP-Operador logístico B ...... 89

Figura 19 - Esquema que relaciona a cadeia de suprimentos, indicadores e atributos 


\section{LISTA DE QUADROS}

Quadro 1 - Comparação entre os canais de distribuição ...................................... 26

Quadro 2 - Aspectos de colaboração logística ................................................. 32

Quadro 3 - Síntese dos atributos da revisão de literatura ................................... 41

Quadro 4 - Rodízio de carros e caminhões ...................................................... 56

Quadro 5 - Acompanhamento de entrega na RMSP - Estudo de caso A.................65

Quadro 6 - Acompanhamento de entrega na RMSP - Estudo de caso B.................65

Quadro 7 - Síntese dos resultados propostos ............................................... 68

Quadro 8 - Características dos Clientes - Estudo de caso A................................. 73

Quadro 9 - Síntese dos atributos de distribuição - Estudo de caso A ..................... 81

Quadro 10 - Características dos Clientes - Estudo de caso B............................. 87

Quadro 11 - Síntese dos atributos de distribuição - Estudo de caso B ...................98

Quadro 12 - Principais papéis desempenhados pelos agentes na distribuição de

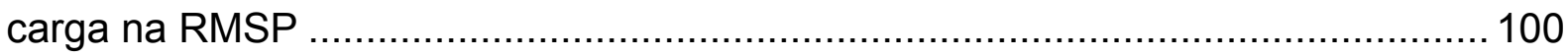

Quadro 13 - Síntese dos atributos: Revisão da literatura e Estudos de caso ......... 102

Quadro 14 - Atributos de distribuição urbana de carga na RMSP mais relevantes 113

Quadro 15 - Indicadores logísticos - melhores e piores desempenhos................116

Quadro 16 - Síntese dos atributos: Revisão da literatura, Estudos de caso e Levantamento de dados 


\section{LISTA DE TABELAS}

Tabela 1 - Evolução da frota no município de São Paulo por tipo de veículo 54

Tabela 2 - Entrevistas com representantes das empresas - Estudo de caso A 64

Tabela 3 - Entrevistas com representantes das empresas - Estudo de caso B 64

Tabela 4 - Taxa de resposta por prestador de serviços logísticos 67

Tabela 5 - Desempenho de entrega em 2012 77

Tabela 6 - Perfil dos respondentes 108

Tabela 7 - Perfil das entregas na RMSP 109

Tabela 8 - Medidas descritivas dos atributos de distribuição sob a ótica do Operador logístico.

Tabela 9 - Medidas descritivas dos atributos de distribuição sob a ótica do Transportador

Tabela 10 - Medidas descritivas dos indicadores de desempenho logístico sob a ótica do Operador logístico

Tabela 11 - Medidas descritivas dos indicadores de desempenho logístico sob a ótica do Transportador 


\section{SUMÁRIO}

1 INTRODUÇÃO...........................................................................

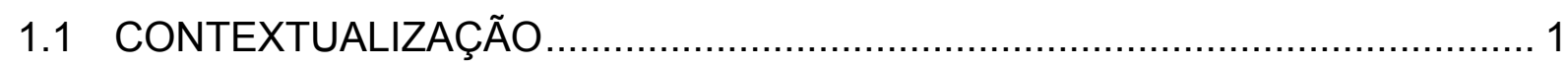

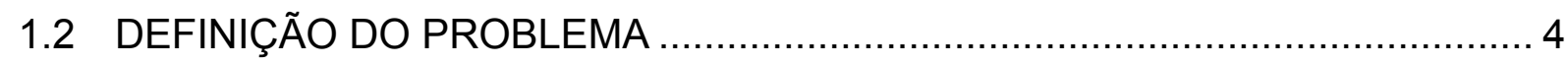

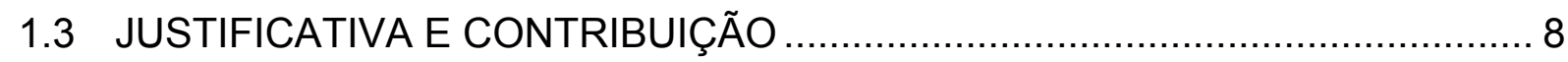

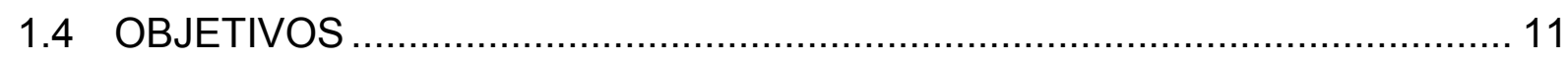

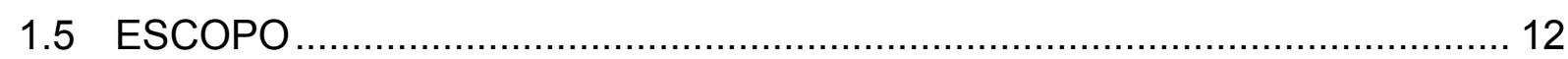

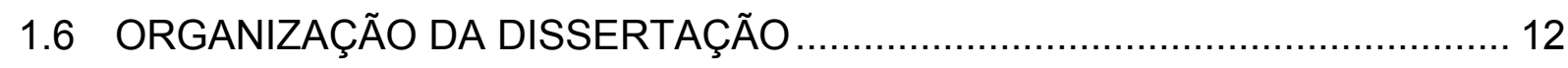

2 REVISÃO DE LITERATURA ........................................................15

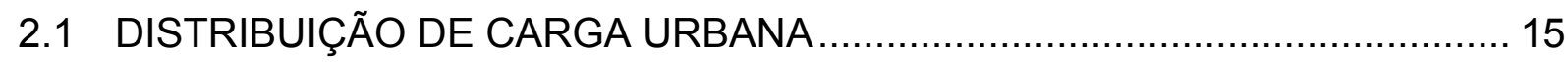

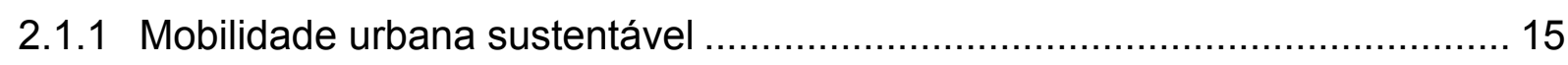

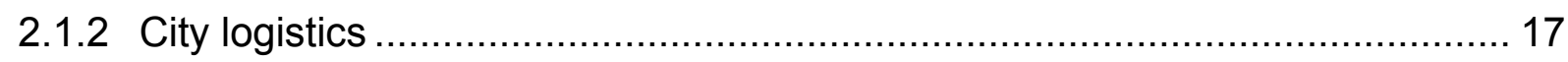

2.1.3 Agentes e estrutura de distribuição urbana de carga .................................. 19

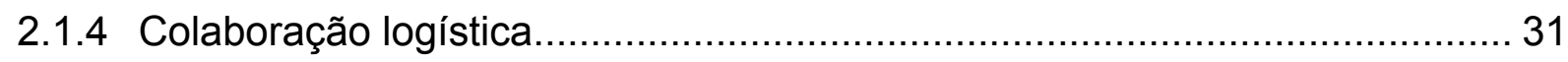

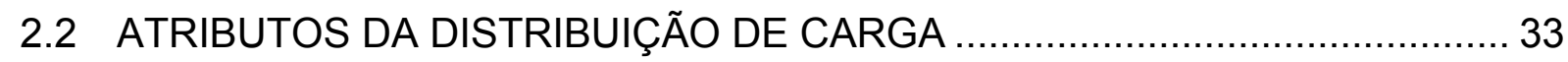

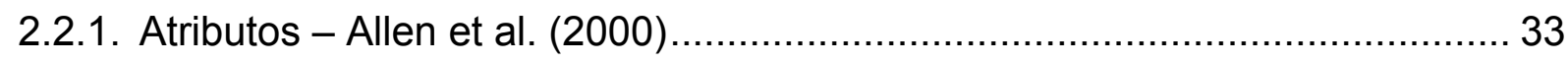

2.2.2. Atributos - Ljungberg e Gebresenbet (2005) .......................................... 34

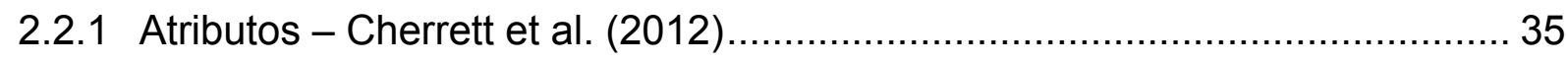

2.2.2 Atributos - Sanches Junior (2008) …………....................................... 36

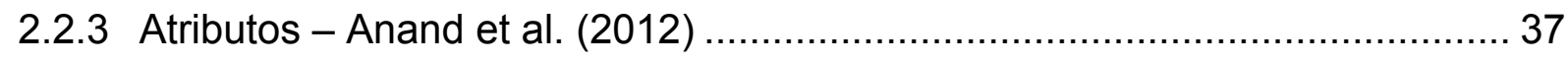

2.2.4 Atributos - Browne et al. (2012) .............................................................. 37

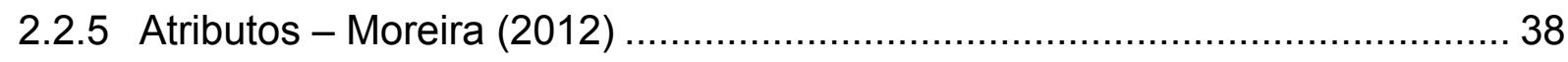

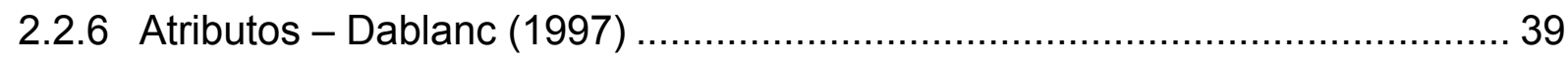

2.2.7 Síntese dos atributos levantados na revisão de literatura .............................. 40

2.3 INDICADORES DE DESEMPENHO LOGÍSTICO …..................................... 47

2.4 REGIÃO METROPOLITANA DE SÃO PAULO .............................................. 51

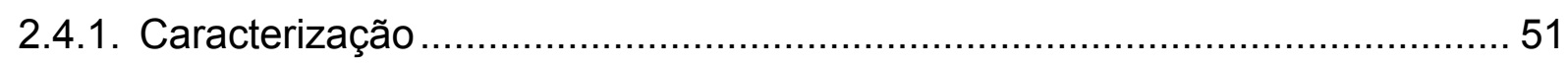


2.4.1 Políticas para transporte urbano

3 METODOLOGIA DE PESQUISA ...............................................59

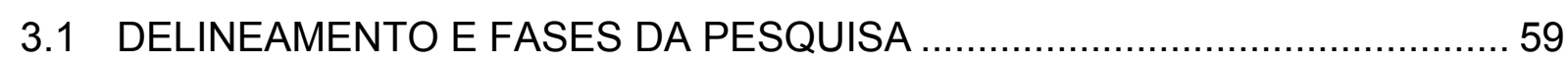

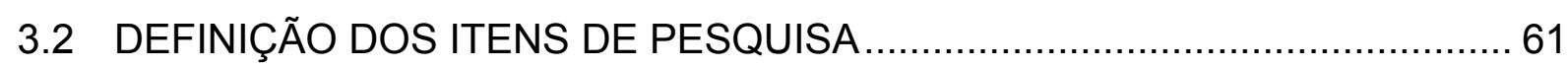

3.3 PROCEDIMENTOS METODOLÓGICOS DO ESTUDO DE CASO …................ 62

3.4 PROCEDIMENTOS METODOLÓGICOS DA COLETA DE DADOS .................66

3.5 PROCEDIMENTOS METODOLÓGICOS DA ANÁLISE DOS DADOS ............ 67

3.6 CONSIDERAÇÕES FINAIS SOBRE A METODOLOGIA ...............................67

4 RESULTADOS: ESTUDOS DE CASO A E B..................................69

4.1 CASO A - APRESENTAÇÃO DO OPERADOR LOGÍSTICO A E

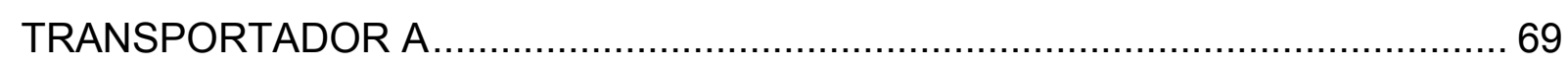

4.2 CASO A - APRESENTAÇÃO DOS EMBARCADORES E SEUS CLIENTES

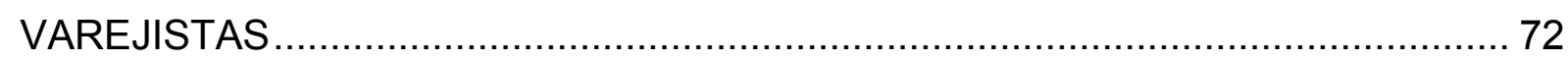

4.3 CASO A - PAPÉIS DOS AGENTES E A ESTRUTURA DE DISTRIBUIÇÃO ... 74 4.4 CASO A - ATRIBUTOS DE DISTRIBUIÇÃO DE CARGA E INDICADORES DE DESEMPENHO LOGÍSTICO............................................................................... 76

4.5 CASO B - APRESENTAÇÃO DO OPERADOR LOGÍSTICO B E TRANSPORTADOR B. 83

4.6 CASO B - APRESENTAÇÃO DOS EMBARCADORES E SEUS CLIENTES VAREJISTAS 85

4.7 CASO B - PAPÉIS DOS AGENTES E A ESTRUTURA DE DISTRIBUIÇÃO ... 89 4.8 CASO B - ATRIBUTOS DE DISTRIBUIÇÃO DE CARGA E INDICADORES DE DESEMPENHO LOGÍSTICO. 92 4.9 ANÁLISE INTERCASOS. 100

5 RESULTADOS: LEVANTAMENTO DE DADOS COM OPERADORES LOGÍSTICOS E TRANSPORTADORES (SURVEY).107

5.1 PERFIL DOS RESPONDENTES E ENTREGAS NA RMSP. 107

5.2 APRESENTAÇÃO DOS ATRIBUTOS MAIS RELEVANTES NA DISTRIBUIÇÃO URBANA NA RMSP 110

5.3 ANÁLISE DOS INDICADORES DE DESEMPENHO LOGÍSTICO NA RMSP.114 6 ANÁLISE CRUZADA DOS RESULTADOS (ESTUDOS DE CASO E SURVEY 
6.1 PAPÉIS E REPONSABILIDADES DOS AGENTES (OPERADOR LOGÍSTICO E

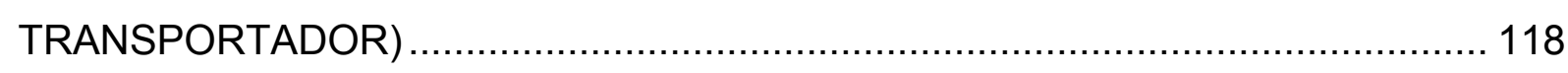

6.2 OS ATRIBUTOS DE DISTRIBUIÇÃO URBANA DE CARGA E SEU IMPACTO

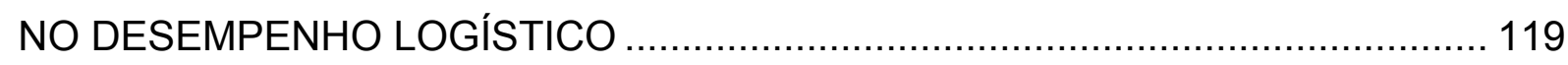

7 CONCLUSÕES......................................................................122

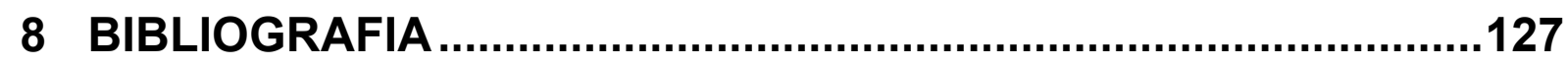

APÊNDICE A - PROTOCOLO DE ENTREVISTA: OPERADOR LOGÍSTICO E TRANSPORTADOR.....................................136

APÊNDICE B - QUESTIONÁRIO DE PESQUISA......................141 


\section{INTRODUÇÃO}

\subsection{CONTEXTUALIZAÇÃO}

A população urbana mundial tem crescido rapidamente nas últimas décadas. Segundo dados da Organização das Nações Unidas (ONU) na Rio+20, em 2012, o mundo está se tornando predominantemente urbano. Durante os anos de 1950 a 2011 observou-se um crescimento de 750 milhões para 3,6 bilhões de habitantes vivendo em cidades, o que representa cerca de metade da população mundial. Em 20 anos seis em cada dez pessoas no mundo vão viver em áreas urbanas, sendo que esse crescimento será concentrado em países em desenvolvimento.

Um dado significativo é que cerca de $14 \%$ da população urbana da América Latina e Caribe (ou 65 milhões de pessoas) vivem em megacidades, consideradas como aglomerados urbanos com mais de 10 milhões de habitantes (ONU, 2006). Esse dado destaca a região da América Latina como a maior concentração mundial de megacidades, sendo elas: Cidade do México, São Paulo, Buenos Aires e Rio de Janeiro. Portanto, lugares que necessitam de pesquisas com o objetivo de melhorar o fluxo logístico, a eficiência das empresas e investimento adequado do poder público no sistema de transporte de carga e de passageiro.

Somado ao crescimento da população urbana, pode-se observar o aumento da densidade demográfica nas cidades que representam apenas $2 \%$ do território mundial e são responsáveis por $70 \%$ das emissões de dióxido de carbono. Nessa linha, a logística urbana, que contempla o transporte de carga e pessoas nas cidades, é responsável por $13 \%$ da emissão global de gases-estufa e, segundo estimativas da ONU $\left(2012^{a}\right)$, os países emergentes vão contabilizar $80 \%$ do crescimento projetado de emissão de gases-estufa até 2030.

Nesse contexto, a distribuição urbana de carga é um elemento chave da vida econômica dos centros urbanos e um serviço essencial para o funcionamento do fluxo logístico da cidade. O estudo apresentado por Allen et al. (2000) destaca os aspectos econômicos e sociais relacionados à distribuição urbana de carga em 
termos de eficiência em custo, tais como sua relevância no custo das commodities e na competitividade das empresas dos diversos segmentos da indústria, comércio ou prestadoras de serviços, além dos aspectos ambientais, como consumo de energia, geração de ruído e poluição.

Por outro lado, sob o ponto de vista das empresas que realizam a distribuição na cadeia de varejo, segundo Lima Junior (2005), os participantes da cadeia de suprimento das indústrias que atuam no mercado varejista têm enfrentado um aumento de complexidade do processo de distribuição com a redução ou eliminação de estoques decorrentes de uma política de abastecimento "Just in Time" (JIT), aumento da frequência de reposição de estoques, diminuição do tamanho de pedidos e lotes de entrega, podendo gerar impactos negativos em custos, cobrança por eficiência, confiabilidade e regularidade na distribuição, além do aumento do fluxo urbano de veículos de carga. Além disso, as indústrias se deparam com diversas dificuldades no processo de distribuição de cargas nesses mercados, tais como: atrasos no descarregamento causados por filas, dificuldades no atendimento das janelas de entrega, zonas e horários de restrição de circulação de veículos de carga, congestionamentos e restrições por final de placa, entre outros.

Em paralelo, o comportamento do consumidor tem mudado de forma acelerada, agravando ainda mais a mobilidade urbana, por conta do aumento crescente de compras pela internet e com ampla diversidade de produtos. O comércio eletrônico é responsável por um dos problemas atuais nas atividades de distribuição de mercadorias em áreas urbanas, podendo aumentar o número total de viagens e os custos logísticos, devido à baixa densidade, alta dispersão geográfica, entregas domiciliares com definição de janelas de tempo, além de múltiplas tentativas de entrega decorrentes da ausência do cliente (OLIVEIRA, 2007).

Da mesma forma, a empresas fabricantes e seus fornecedores não estão mais limitados ao mercado local e passam a desempenhar papéis diferentes à medida que terceiriza os serviços logísticos. Devido à globalização, a maior distância entre os processos de produção e de consumo aumenta a pressão para alcançar níveis mais elevados de desempenho logístico. Logo, a eficiência na distribuição urbana de mercadorias é um fator também relevante que pode aumentar a competitividade das empresas fabricantes (embarcadores) que gerenciam as suas operações de 
armazenagem e distribuição ou terceirizam esta atividade para empresas prestadoras de serviços logísticos (operadores logísticos e transportadores). Mas, por outro lado, quando se trata de megacidade, essa eficiência pode ser afetada por problemas como tráfego intenso, falta de área para carga e descarga, roubo, entregas em lugares de difícil acesso, acesso restrito por veículos de carga, etc.

É fato que, alguns aspectos da logística de distribuição como falta de sistema de roteirização de entregas, falta de treinamento de motoristas, baixas taxas de ocupação do veículo e agilidade na entrega, entre outros, podem contribuir para a competitividade das empresas, enquanto outros podem dificultar a eficiência das empresas, tais como: falta de um local adequado para carga e descarga, restrição de circulação de caminhão, aumento do número de veículos de carga, filas e alta frequência de entrega de pequenos volumes.

De um lado, uma das formas para que as empresas tenham um bom desempenho logístico é a colaboração (VIEIRA; YOSHIZAKI; HO, 2010). Um exemplo disso, com o objetivo de reduzir custos logísticos e melhorar seu desempenho, as grandes redes de supermercados e seus fornecedores têm investido em novos modelos de parcerias ou acordos colaborativos (VIEIRA; YOSHIZAKI; LEE, 2009a). Além disso, uma boa gestão dos fluxos logísticos, por meio do uso eficiente de modais de transporte, gerenciamento dos estoques, localização adequada de pontos de distribuição e tecnologia de informação, podem impactar positivamente o desempenho logístico.

Por outro lado, outros fatores podem influenciar negativamente a distribuição de cargas nos centros urbanos. Segundo Ogden (1992), a movimentação de carga nas cidades pode enfrentar problemas estruturais como malha viária deficiente, vias estreitas e falta de manutenção da pavimentação, problemas relacionados à mobilidade devido a programação inadequada dos semáforos, congestionamentos causados por carga e descarga nas vias, além de problemas gerados pela falta de estacionamento privado, regulamentação de vagas públicas e áreas específicas para carga e descarga em centros urbanos.

Diante desta complexidade, a logística urbana requer uma abordagem sistêmica, a fim de entender as expectativas e os interesses das empresas que participam desse processo, minimizando os conflitos e os impactos econômicos, sociais e ambientais, 
promovendo um processo de distribuição de carga mais eficiente e sustentável. Taniguchi et Van der Heijden (2000) propõem que as ações que buscam aumentar a eficiência neste campo devem ser focadas na otimização global da logística urbana embasadas no conceito de City Logistic.

Logo, o propósito desta dissertação é identificar os papéis dos principais agentes participantes da distribuição urbana de carga, Embarcador, Operador Logístico, Transportador e Cliente, e levantar os aspectos positivos e negativos desse processo sob o ponto de vista dessas empresas. Além disso, é desejável entender os indicadores de desempenho utilizados pelas empresas que podem sofrer impactos desses aspectos de entrega na grande cidade.

\subsection{DEFINIÇÃO DO PROBLEMA}

Os aspectos apresentados referentes à complexidade da logística urbana são um fato, e a região metropolitana de São Paulo (RMSP) possui características que agravam ainda mais esta situação, que serão descritas a seguir. Neste sentido, também serão utilizadas informações da cidade de São Paulo que não estão disponíveis para a RMSP e/ou são relevantes para a definição do problema.

Capital do Estado de São Paulo, o município de São Paulo compõe com outros 38 municípios vizinhos a região metropolitana de São Paulo (RMSP), uma das 36 regiões metropolitanas do Brasil (Figuras 1 e 2) com população de aproximadamente 19,9 milhões de pessoas (48,04\% da população do Estado de São Paulo), área de 8.051 km2 (3,24\% da área do Estado de São Paulo).

Na RMSP, cada município tem seu próprio Governo, o que dificulta a adoção de uma estratégia de planejamento integrado, a fim de promover melhorias estruturais para as cidades (OBSERVATÓRIO CIDADÃO NOSSA SÃO PAULO, 2008). 


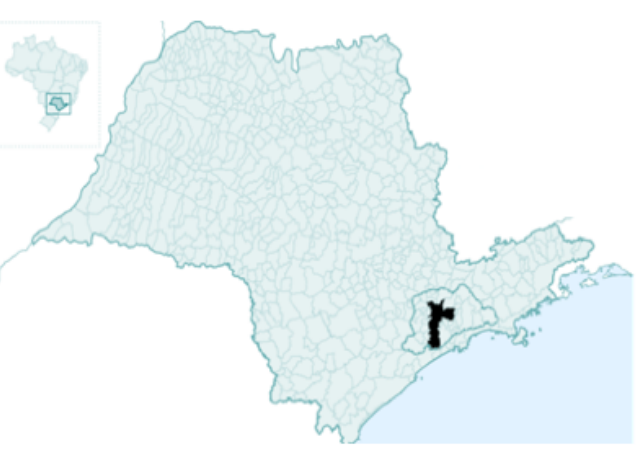

Figura 1 - Mapa do Estado de São Paulo Fonte: Governo do Estado de São Paulo (2013)

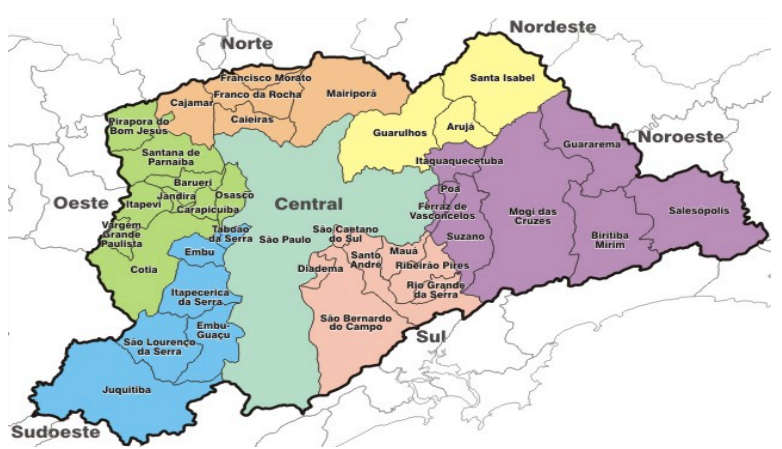

Figura 2 - Mapa da RMSP e Cidade de São Paulo Fonte: Prefeitura da Cidade de São Paulo (2013)

De acordo com relatório publicado pela ONU em 2012, "World Urbanization Prospects- The 2011 Revision", a RMSP é o maior aglomerado urbano da América Latina e o sexto do mundo (Figura 3). Além disso, a cidade de São Paulo, isoladamente, poderia ser classificada como uma das 23 megacidades apresentadas nesse relatório, ocupando posição superior em relação a cidades como Istambul e Paris.

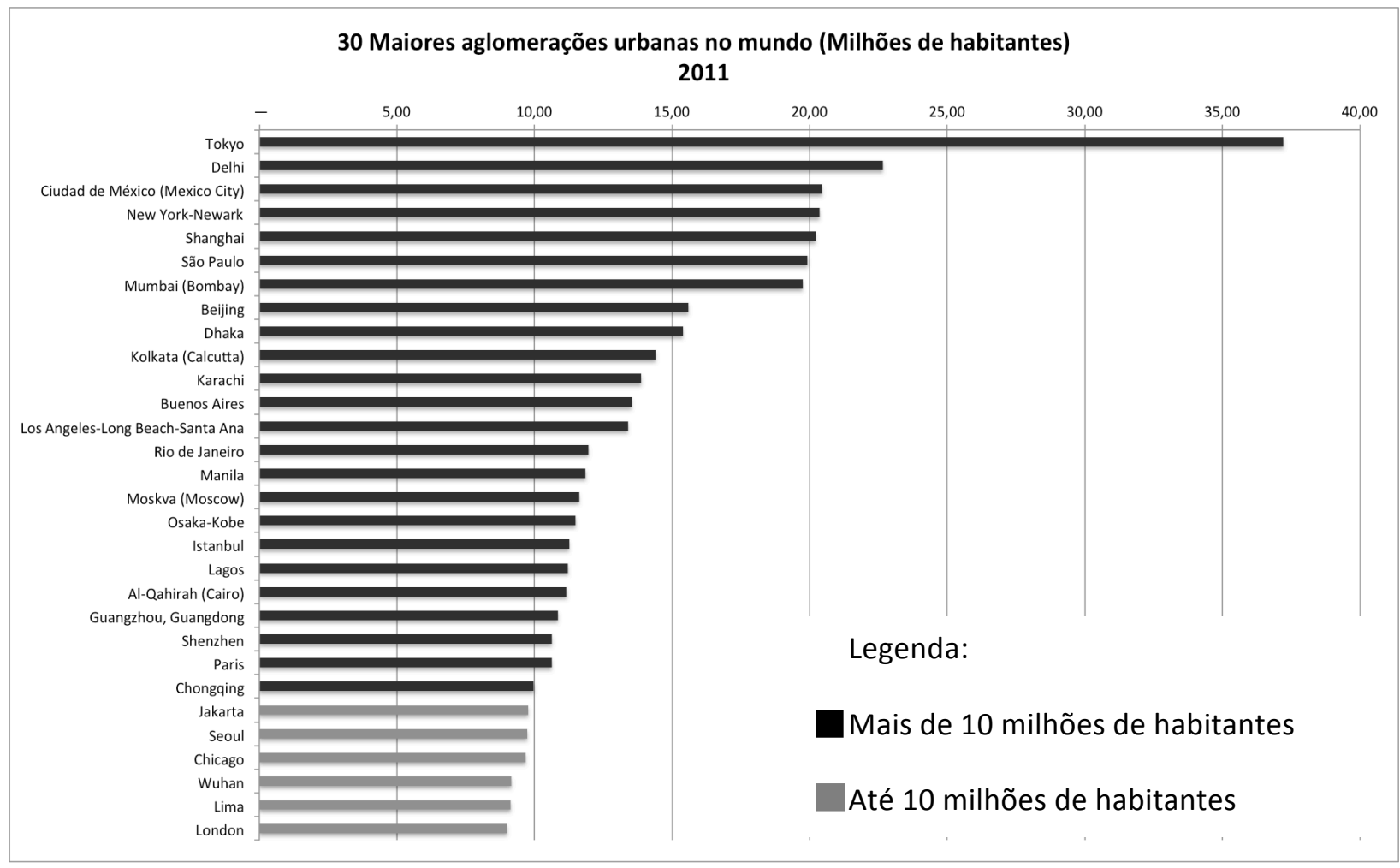

Figura 3 - Maiores aglomerações urbana no mundo Fonte: ONU (2012)

A densidade demográfica da cidade de São Paulo é a mais elevada do Brasil, 7.387,69 habitantes/km2 (IBGE, 2010). Além disso, a ocupação das regiões periféricas da cidade de São Paulo apresenta assentamentos informais em sua 
maioria, o que provoca impactos ambientais negativos prejudicando a qualidade de vida, mobilidade e acessibilidade. A população tem que mover-se diariamente da periferia para as áreas com maior concentração de postos de trabalho que ficam próximas ao centro da cidade, sobrecarregando o sistema de transporte público e aumentando o congestionamento das vias e estradas. Logicamente, isso também é um desafio para que as empresas tenham acesso a essas regiões e façam a distribuição de mercadorias eficientemente.

Portanto, esta dissertação tem como objeto de estudo a RMSP, dada a complexidade de distribuição de carga urbana diante dos desafios do crescimento apresentado. Neste sentido, procurou-se levantar algumas características relacionadas à mobilidade urbana, ao sistema regulatório para acesso de veículos nos grandes centros, aos aspectos ambientais, às entregas em área de risco, entre outros, que podem comprometer a eficiência das empresas no tocante à distribuição de mercadorias na RMSP. Algumas dessas características são:

- Elevado índice de congestionamentos nos horários de pico: segundo indicador mensal dos congestionamentos nos horários de picos em dias úteis publicados pela Companhia de Engenharia de Tráfego de São Paulo (CET-SP), em 2013, o mês de março apresentou a maior média mensal do ano, foram $137 \mathrm{~km}$ de vias congestionadas dos $835 \mathrm{~km}$ monitorados no horário de pico da tarde. O recorde diário em 2013 registrado pela CET-SP, até o momento, foi de $282 \mathrm{~km}$ de vias congestionadas às 19 h30 do dia 12/06/2013.

- Excesso de veículos: a frota de veículos da cidade de São Paulo ultrapassou a marca dos 7,3 milhões em 2012, representando $70 \%$ da frota de veículos da RMSP. Atualmente, são mais de 10,8 milhões de veículos circulando na RMSP, sendo 7,6 milhões de automóveis e apenas 245,5 mil caminhões, segundo dados do Departamento Estadual de Trânsito de São Paulo (DETRAN-SP, 2013).

- Chuvas e Alagamentos: as chuvas e alagamentos agravam consideravelmente o trânsito da cidade. Segundo dados do CET-SP, o recorde absoluto de congestionamento ocorreu em 01/06/2012, com 295 km de congestionamento na cidade causado pelo elevado número de veículos, fortes chuvas e pontos de alagamento. O órgão do governo responsável pelo monitoramento das condições meteorológicas e potenciais riscos de alagamentos na cidade de São 
Paulo é o Centro de Gerenciamento de Emergência (CGE), que fica alocado na central de operações da CET-SP.

Com o objetivo de evitar que a situação do trânsito se agrave, melhorar a mobilidade urbana, reduzir os ruídos e a poluição do meio-ambiente, a cidade de São Paulo possui normas de trânsito definidas por: (a) zonas de restrição de circulação de caminhão por tamanho e capacidade de veículo e por horário; (b) rodízio de carros em determinadas vias da cidade de acordo com o dia da semana e final da placa, o que se aplica tanto aos automóveis quanto aos caminhões; e (c) possui um programa de inspeção de emissão de poluentes liberados pelos escapamentos, que é obrigatória para todos os veículos registrados na cidade.

Como mencionado, esses sistemas regulatórios e características inerentes à distribuição de carga na grande São Paulo podem impactar o desempenho da distribuição de mercadorias na RMSP, uma vez que os demais agentes (embarcadores, operadores logísticos, transportadores e cliente) têm que se adequar às normas estabelecidas e, possivelmente, alterar a estratégia de atuação no mercado para efetuar a entrega/recebimento das mercadorias, adotar rotas diferenciadas, entregas em horários diversos, entre outros. Assim, iniciativas de colaboração entre dois ou mais agentes podem ser consideradas como alternativas para minimizar impactos nas operações logísticas destas empresas, como, por exemplo, compartilhamento de informação entre os destinatários finais e o entregador.

Além disso, essas empresas têm papéis diferentes na distribuição de carga. Enquanto o embarcador tem foco na produção e atendimento diversificado de produtos a clientes varejistas, os operadores logísticos e transportadores têm foco nas operações logísticas. O Embarcador pode contratar a transportadora para realizar a entrega direta ao cliente final ou pode contratar o operador logístico para fazer armazenagem, etiquetagem, transporte, etc.; ou até dispor de frota própria para realizar as operações de distribuição. Enquanto que o operador logístico busca oferecer serviços logísticos diferenciados aos seus clientes embarcadores, as transportadoras atuam mais localmente com foco no transporte final (última milha).

Portanto, o presente trabalho busca responder as seguintes questões: "Quais são os papéis desempenhados pelos Embarcadores, Operadores logísticos, 
Transportadores e Clientes na distribuição urbana de carga?" "Quais são os atributos que regem a distribuição urbana de carga na região metropolitana de São Paulo (RMSP) sob a ótica dos Operadores Logísticos e Transportadores, e seus possíveis impactos no desempenho dessas empresas?"

\subsection{JUSTIFICATIVA E CONTRIBUIÇÃO}

As pesquisa relacionadas ao transporte de carga têm vários objetivos e são realizadas sob diferentes pontos de vista. Contudo, ainda há uma lacuna que se refere à distribuição de carga sob o ponto de vista das empresas responsáveis por este processo. Algumas pesquisas relevantes sobre distribuição de carga em grandes centros e a geração de externalidades foram conduzidas por Antún et al. (2010), Browne et al. (2012), Castro, Kuse e Hyodo (2003), Costabile e Allegrini, (2008), Muñuzuri et al. (2012).

Algumas relevantes pesquisas descritas a seguir ajudam a justificar e encaixar a proposta desta dissertação. Embora essas pesquisas tenham abordado diferentes focos, elas têm correlação com esta dissertação.

De Vasconcellos (2005), por meio de um amplo levantamento de dados, analisa as mudanças que ocorreram em quatro décadas, de 1967 a 1997, no sistema de transporte e nas condições do tráfego na RMSP, com foco nos aspectos de mobilidade urbana. Segundo o autor, o sistema de transporte público ineficiente e o aumento do uso de carros particulares estão relacionados com o aumento dos índices de acidentes, congestionamento e poluição, ameaçando a sustentabilidade da RMSP.

Esses problemas têm sido agravados pelo crescimento da população urbana, pela crise no modelo de mobilidade urbana adotado nas grandes cidades brasileiras e aumento da complexidade do processo de distribuição urbana de carga. As externalidades negativas geradas pela distribuição urbana de cargas como congestionamentos, poluição e ruídos, são amplamente conhecidas e vivenciadas pela população que vive em grandes centros urbanos. 
Porém, tal pesquisa foi realizada sob o ponto de vista dos agentes do sistema logístico. Pode-se inferir que grande parte da literatura disponível sobre distribuição urbana de carga se resume em como o setor público pode minimizar essas externalidades negativas e melhorar a eficiência do transporte de carga. Entretanto, na maioria das vezes, não considera os papéis da partes interessadas e demais aspectos da distribuição de carga (ANAND et al; 2012).

Esta dissertação procura estudar a distribuição de carga sob o ponto de vista das empresas. Ou seja, qual a percepção delas quanto aos desafios inerentes à distribuição de mercadoria, quais os possíveis impactos que podem ser gerados, a partir desses desafios, no desempenho das empresas. Além disso, procura-se investigar como as empresas se relacionam nesse processo.

Stathopoulos, Valeri e Marcucci (2012) desenvolveram uma pesquisa similar. Os autores estudaram as entregas de mercadorias na cidade de Roma levando em consideração o ponto de vista e o relacionamento entre alguns dos agentes responsáveis pela distribuição de carga, tais como: transportadores locais e independentes, empresas transportadoras que atendam a diversos pontos do país, operadores logísticos, embarcadores e varejistas. Nesse estudo foram analisadas algumas características referentes às regulações de tráfego na Zona de restrição de Roma, entregas noturnas, variação da janela de tempo de entrega, falta de locais adequados para cargas e descarga, incentivo ao uso de biocombustível, entre outras.

Recentemente, Ballantyne, Lindholm e Whiteing (2013) também analisaram algumas percepções das autoridades locais e dos operadores de carga (transportadoras e operadores logísticos) quanto ao sistema de transporte na área urbana de grandes centros na Inglaterra, Suécia e região do Mar Báltico, além de investigar o relacionamento entre os agentes.

Na mesma linha, outro estudo conduzido por Lindholm e Behrends (2012) analisou quatro cidades da região do Mar Báltico sob o ponto de vista das empresas de transporte e do governo. Os autores concluiram que ambos os agentes negligenciam os problemas dos grandes centros e existe pouca colaboração entre eles. Enquanto os governantes focam no transporte público e estabelecem normas e restrições de acesso a veículos pesados e em horários de pico, as empresas focam meramente 
em seu desempenho e têm pouca participação nas decisões e planejamentos para os grandes centros.

Portanto, este trabalho pretende contribuir com a identificação dos papéis dos principais agentes participantes da distribuição urbana de carga, Embarcador, Operador logístico, Transportador e Cliente, por meio de estudo de caso conduzido em dois Operadores Logísticos, assim como a identificação dos aspectos de distribuição urbana de carga que podem impactar o desempenho logístico desses agentes na distribuição de carga na RMSP.

No Brasil, os aspectos de distribuição urbana relacionados ao desempenho logístico das empresas que atuam no canal de distribuição de carga têm sido objeto de estudo de pesquisas por meio de levantamento de dados junto aos principais agentes envolvidos na identificação dos interesses e iniciativas de melhoria de desempenho logístico (DUTRA, 2004; SANCHES JUNIOR, 2008; MOREIRA, 2012; TACLA, 2010). Contudo, Sanches Junior (2008) defende que existe uma lacuna de vinte anos com relação aos estudos e pesquisas sobre a distribuição de carga urbana quando comparado com a União Europeia.

Adicionalmente, a abordagem do tema "Logística da distribuição urbana de carga" e o desempenho logístico da distribuição tem sido conduzida de forma segmentada, com foco em determinados aspectos da distribuição de carga (HESSE; RODRIGUE, 2004). Por exemplo, Dutra (2004) apresenta em seu estudo os efeitos da adoção de práticas sustentáveis nos ganhos ambientais e na competividade para as empresas envolvidas na movimentação de carga.

Portanto, esta dissertação busca investigar, dentro de uma amostra de empresas, as percepções quanto aos problemas que elas enfrentam diariamente na distribuição de carga em grandes centros sob diferentes aspectos. Esse problemas estão divididos em cinco grupo, tais como: logísticos (uso de sistemas para troca eletrônica de dados, taxa de ocupação de veículo, entrega, longa fila de espera, etc.), de colaboração (falta de comprometimento no recebimento de mercadoria pelo cliente, falta de flexibilidade de mudança de horário, falta de confiança na entrega, etc.), regulatórios (tráfego intenso, falta de área adequada para estacionamento, carga de descarga, etc.), ambientais (incentivo de uso de óleo biocombustível, controle de emissão de $\mathrm{CO} 2$, etc.) e de risco (roubo de carga, enchentes, etc.). 
Certamente o estudo desses aspectos e a relação deles com o desempenho logístico das empresas podem ajudar a definir o planejamento de ações estabelecidas pelos governantes e também identificar os pontos fracos que as empresas precisam melhorar para atender os seus clientes com melhor nível de serviço a um menor custo logístico.

Nesta dissertação esses problemas da grande cidade ou características que dificultam o acesso para distribuição de carga e, também, características que identificam colaboração, serão denominado de "atributo de distribuição de carga". Por exemplo, o atributo "tempo de viagem", "janela de entrega", "demanda por tamanho de veículo para entrega", entre outros, serão definidos como atributos logísticos. Já "compartilhamento de informações", "flexibilidade", "comprometimento" etc., serão definidos como atributos de colaboração.

\subsection{OBJETIVOS}

Esta dissertação tem por objetivo identificar os atributos de distribuição urbana de carga, levando-se em conta os diferentes pontos de vista dos principais responsáveis pela distribuição de carga na RMSP e que atuam no mercado varejista: Embarcador, Operador Logístico, Transportador e Cliente, identificando:

1 Os papéis fundamentais dos agentes: Embarcador, Operador Logístico, Transportador e Cliente, Este objetivo contempla o estudo de atributos de distribuição urbana de carga que podem impactar o desempenho logístico desses agentes na distribuição de carga na RMSP.

Para tanto, foram desenvolvidos dois estudos de caso em Operadores logísticos que atuam nos setores de: a) higiene pessoal, produtos hospitalares e correlatos; b) vestuários e artigos esportivos, e produtos químicos.

2 A relevância dos atributos levantados na literatura e nos estudos de caso, sob a ótica dos prestadores de serviços logísticos, Operador logístico e Transportador, que atuam na distribuição de carga na RMSP. 
Para tanto, foi realizado um levantamento de dados por meio de questionário aplicado junto às empresas prestadoras de serviços logísticos, Operador logístico e Transportador.

\subsection{ESCOPO}

Este estudo tem como escopo a distribuição urbana de carga limitada aos atributos e papéis dos embarcadores, operadores logísticos, transportadores e clientes, participantes da logística de distribuição no mercado varejista na RMSP, referentes às seguintes atividades: coleta, armazenagem, consolidação e distribuição.

Para tanto, sempre que possível, a pesquisa procurará se pautar nos problemas da RMSP. No entanto, dada a representatividade da cidade de São Paulo e na ausência de dados específicos da RMSP, serão utilizados dados da cidade de São Paulo que podem vir a contribuir para o desenvolvimento desta pesquisa. Neste sentido, não serão estudadas as particularidades das demais cidades que compõe a RMSP como, por exemplo, normas de circulação de veículos, leis ambientais e ocupação de espaço físico.

Caso necessário, os papéis dos demais agentes, comunidade, autoridades locais, fabricantes de veículos, entre outros, serão identificados indiretamente através das percepções dos demais agentes e observações realizadas no campo pela pesquisadora.

\subsection{ORGANIZAÇÃO DA DISSERTAÇÃO}

Esta dissertação está organizada em 07 (sete) capítulos iniciando-se por esta Introdução. A seguir, será apresentado o detalhamento dessa estrutura:

Capítulo 1: Introdução - Este capítulo tem por finalidade apresentar as linhas gerais do trabalho, incialmente contextualizando a logística urbana e descrevendo a 
complexidade do tema distribuição de carga em megacidades, para então definir os problemas de pesquisa. Na sequência, são apresentadas as justificativas e contribuição que reforçam a relevância do tema. Por fim, são especificados os objetivos deste trabalho, dentro do escopo e delimitação da pesquisa previamente definidos.

Capítulo 2: Revisão da Literatura - Trata do referencial teórico sobre o tema distribuição urbana de carga, especificamente sobre os aspectos da mobilidade urbana, o conceito de City Logistic, os agentes participantes e suas expectativas e papéis, as estratégias e canais de distribuição ao varejo e, por fim, um levantamento dos atributos que influenciam a distribuição urbana de carga. Este capítulo é de extrema relevância para os capítulos descritos a seguir, uma vez que se pretende fundamentar os itens de pesquisa.

Capítulo 3: Metodologia da pesquisa - Este capítulo apresenta o método a ser empregado na pesquisa, os procedimentos e instrumentos que serão utilizados no estudo de caso e levantamento de dados, e também como os dados da pesquisa serão tratados e analisados.

Capítulo 4: Resultados - Estudos de Caso A e B

Os estudos de caso são compostos pela apresentação, discussão e análise intercasos, e procura apresentar os papéis dos agentes participantes da distribuição de carga na RMSP, sob o ponto de vista dos embarcadores, operadores logísticos, transportadoras e cliente varejista. É também feito um levantamento dos atributos de distribuição e uma discussão à respeito de um provável impacto desses atributos de distribuição de carga no desempenho logístico dessas empresas.

Capítulo 5: Resultados - Levantamento de dados com Operadores logísticos e Transportadores (Survey)

O levantamento de dados, realizado com uma ampla amostra de empresas, identifica a relevância dos atributos de distribuição urbana de carga que podem vir a impactar o desempenho logístico da distribuição de carga na RMSP. Para isso, foram realizadas análises de medidas descritivas dos atributos e também dos indicadores de desempenho que essas empresas direcionam mais esforços para atender às necessidades de seus clientes. Na realidade, esses dados se referem a 
percepções que os respondentes têm a respeito dos problemas da RMSP e da eficiência no desempenho logístico.

Capítulo 6: Análise Cruzada dos Resultados (Estudos de Caso e Survey) - este tópico apresenta a análise dos resultados encontrados nos dois métodos empregados nesta pesquisa.

Capítulo 7: Conclusões finais - apresenta as conclusões relativas ao objetivo dessa pesquisa, com algumas considerações e limitações. 


\section{REVISÃO DE LITERATURA}

A revisão de literatura serviu de base para a fundamentação teórica dos resultados desta dissertação e se refere aos seguintes tópicos: distribuição de carga urbana; atributos que influenciam a distribuição de carga; indicadores de desempenho logístico e características da região metropolitana de São Paulo (RMSP).

\subsection{DISTRIBUIÇÃO DE CARGA URBANA}

Nesse tópico será apresentado o referencial teórico da distribuição urbana de carga fundamentado na abordagem dos conceitos de mobilidade sustentável e City logistics; na discussão dos recursos e papéis dos agentes envolvidos na distribuição urbana de carga; na apresentação de alguns aspectos de colaboração logística que podem vir a contribuir para uma melhor eficiência logística dos agentes envolvidos; na descrição dos canais e estrutura de distribuição ao varejo.

\subsubsection{Mobilidade urbana sustentável}

"A mobilidade urbana é um atributo das cidades, relativo ao deslocamento de pessoas e bens no espaço urbano, utilizando para isto veículos, vias e toda a infraestrutura urbana. Este é um conceito bem mais abrangente do que a forma antiga de tratar os elementos que atuam na circulação de forma fragmentada ou estanque e de administrar a circulação de veículos e não de pessoas" (MINISTÉRIO DAS CIDADES, 2007, p.15).

Ainda segundo o Plano Diretor de Mobilidade (PlanMob) elaborado pelo Ministério das Cidades (2007), através da Secretaria Nacional de Transporte e da Mobilidade (SeMob) e da Diretoria de Mobilidade Urbana (DEMOB), esse conceito apresentado possui mais quatro elementos estruturais oriundos da Política Nacional de 
Mobilidade Urbana sustentável: a inclusão social, a sustentabilidade ambiental, a gestão participativa e a democratização do espaço público (MINISTÉRIO DAS CIDADES, 2004).

Nesse sentido, o conceito mobilidade urbana possui quatro fatores primordiais: a integração entre o planejamento do transporte de pessoas e cargas com o planejamento do uso do solo, melhoria do transporte público de passageiros, estímulo ao transporte não motorizado e uso racional do automóvel (MINISTÉRIO DAS CIDADES, 2004).

A falta de gestão integrada desses fatores pelas autoridades locais e consequente degradação da mobilidade urbana pode comprometer negativamente a qualidade de vida da população e a economia dos centros urbanos. De certa forma, isso reflete também em um sistema de transporte urbano ineficiente, vias públicas precárias e elevado índice de congestionamento. Assim, o PlanMob enfatiza que as cidades brasileiras vivem uma crise da mobilidade urbana, sendo o atual modelo de mobilidade um dos responsáveis pelo elevado número de acidentes no trânsito, congestionamentos crônicos, poluições sonora e atmosférica.

Logo, identificar as ineficiências no sistema de transporte público e melhorar a qualidade do serviço oferecido à população pode tornar o transporte público mais atrativo e, consequentemente, diminuir a utilização de carros particulares, contribuindo para uma mobilidade mais sustentável, com melhor utilização energética, diminuição no tempo de viagem e menor impacto ambiental (SUSNIENÉ, 2012). Além disso, a autora destaca os fatores que são determinantes para a satisfação e atendimento das expectativas dos usuários do transporte público, tais como: confiabilidade, capacidade de resposta e segurança.

No caso específico da cidade de São Paulo, que passa por uma crise de confiabilidade no transporte público relacionada à baixa qualidade do serviço prestado e alto preço das tarifas, o transporte público responde por pouco mais da metade da média diária de deslocamentos motorizados na cidade com $56 \%$ dos deslocamentos, seguido pelo automóvel com aproximadamente $41 \%$ dos deslocamentos, conforme pesquisa sobre origem e destino realizada em 2007 pelo Metrô-SP. Além disso, o município possui a maior frota de carros particulares no Brasil, com mais de 5,3 milhões de automóveis (DETRAN - SP, 2013). 
Nia et al. (2011) defendem que, para se promover um desenvolvimento sustentável do sistema de transporte urbano, as políticas públicas devem considerar, de forma integrada, a ocupação do solo, os aspectos econômicos, financeiros e sociais, além dos impactos ambientais. Além disso, os autores enfatizam que a melhoria do transporte público ocorre através de investimentos e eficiência em custo, e que juntamente com regulamentação e gestão, formam as quatro dimensões de uma política integrada de transporte.

Diante desses conceitos, observa-se uma necessidade de gestão integrada dos sistemas de transporte e que estes estejam em sintonia com uma ocupação espacial mais harmônica e que permita maior eficiência no fluxo de carga no meio urbano. Dentro desse conceito de integração, a city logistic, tema da próxima seção, surge quase como uma necessidade dos agentes envolvidos no mesmo espaço.

\subsubsection{City logistics}

Benjelloun e Crainic (2009) enfatizam que o transporte de carga causa transtornos à vida na cidade, uma vez que também compete por vias e estacionamentos muitas vezes já saturados, comprometendo a mobilidade urbana. No entanto, os autores reforçam que a distribuição urbana de carga não pode ser resumida apenas aos problemas que suas atividades acarretam a sociedade, trata-se, sobretudo, de uma atividade essencial para o bom funcionamento da cidade, à medida que contribui para seu desenvolvimento econômico e social, garantindo que a mercadoria produzida em um determinado local chegue onde será efetivamente consumida.

City logistics abrange além da logística urbana, outros fatores inerentes à complexidade do planejamento e da manutenção das cidades, incluindo não somente a infraestrutura física logística (localização de terminais de carga e descarga, vias de acesso, regulamentação apropriada das operações de carga por caminhões, entre outras), mas, também a segurança viária (GWILLIAM, 2012); questões ambientais (ruído, emissões de gases, vibração em áreas internas) advindas da movimentação de carga; maior qualidade dos serviços de carga (por exemplo, ao evitar congestionamentos, poluição, etc.) e otimização dos custos de 
transporte; e desempenho macroeconômico do setor público de forma a contribuir para o desempenho econômico nos níveis local, regional e nacional (OGDEN, 1992).

Assim, faz-se necessário o envolvimento e colaboração dos diversos agentes envolvidos (Transportador, Embarcador, Operador Logístico, Cliente e Autoridades), na busca por soluções que enderecem os problemas ocasionados ao meio ambiente e a sociedade, sem causar danos às atividades econômicas das cidades. Esse é um dos grandes desafios enfrentados quando se pretende otimizar os procedimentos e as atividades de distribuição urbana de carga, pois deve-se considerar o comportamento e os objetivos de cada agentes envolvidos que, segundo Taniguchi et al. (2007), podem ser resumidos conforme a seguir:

- Embarcador: redução do custo da cadeia de abastecimento.

- Transportador: conciliação da coleta e entrega de carga atendendo as restrições de janela de entrega.

- Morador: redução do ruído e poluição e agilidade no trânsito, menor tráfego de veículos pesados nas vias, etc.

- Autoridades locais: emprego de sistema de transporte sustentável para a cidade.

$\mathrm{Na}$ busca por soluções que venham a resolver estes conflitos de interesses e encontrar alternativas que promovam uma melhoria global do sistema de distribuição urbana de cargas, Taniguchi e Van der Heijden (2000) enfatizam as principais propostas envolvendo parcerias entre os setores públicos e privados, baseadas no conceito de "city logistics", conforme segue:

- Sistemas avançados de informação;

- Sistemas cooperativos de transporte de cargas;

- Terminais logísticos públicos;

- Controle de fator de carregamento;

- Sistemas subterrâneos de transporte de carga.

Portanto, os projetos baseados no conceito de "city logistics" possuem os seguintes objetivos: otimizar as atividades logísticas e de transporte e minimizar os impactos sociais, ambientais, sem causar danos as atividades econômicas das cidades e, consequentemente, elevar a qualidade de vida da população, mobilidade, emissões de gases de efeito estufa e consumo de combustível (TANIGUCHI et al, 2001). 


\subsubsection{Agentes e estrutura de distribuição urbana de carga}

Este tópico tem por objetivo apresentar os papéis, interesses e expectativas dos agentes envolvidos na distribuição urbana de carga, com foco principal nos agentes embarcadores, operadores logísticos, transportadores e clientes. Nesse sentido, pretende-se verificar os possíveis canais e estruturas de distribuição que os embarcadores podem utilizar para o atendimento do mercado varejista visando um melhor desempenho logístico na distribuição urbana de carga.

\subsubsection{Papéis e expectativas dos agentes participantes da distribuição urbana de carga}

Segundo Anand et al. (2012), os agentes envolvidos na distribuição urbana de carga podem ser do setor público (autoridades de trânsito, ferroviárias e portuárias, autoridades de infraestrutura, de ferrovias e de porto, autoridades municipais, etc.) ou agentes do setor privado (embarcador, transportador e cliente).

Anand et al. (2012) defendem que os interesses individuais dos agentes envolvidos no transporte de mercadoria são, na maioria das vezes, conflitantes, e que existem poucos trabalhos que consideram todas as partes interessadas, incluindo suas influências no sistema de transporte urbano de carga. A maior parte da literatura sobre modelagem em transporte urbano de carga disponível se resume em como o setor público pode melhorar a eficiência do transporte urbano de carga sem considerar, na maioria das vezes, os atributos ou comportamentos das demais partes interessadas.

Por exemplo, o principal interesse dos agentes do setor privado é a redução do "custo logístico total", e não apenas do "custo específico do transporte", que é inerente ao processo logístico, uma vez que a produção e o consumo não ocorrem no mesmo local. Por outro lado, o setor público tem como principal interesse a redução do custo social total envolvido no transporte de mercadorias na cidade, pois é responsável tanto pela manutenção quanto pelo desenvolvimento da economia da cidade Ogden (1992). Apesar do setor público não ter um papel central no processo 
decisório, ele acaba interferindo na tomada de decisão por parte dos demais agentes por meio da aplicação de normas e políticas públicas (ANAND et al., 2012).

Segundo Kant et al. (2012), o objetivo principal das Autoridades é atender aos interesses da população impactada pelo transporte de cargas, através da criação de normas que reflitam as constantes preocupações com o meio ambiente, ruídos, acessibilidade da cidade e segurança no trafego, sendo as restrições de circulação por período determinado e tipo de veículos as políticas adotadas com maior frequências. No entanto, na maioria das vezes, não existe uma ação coordenada da aplicação das normas em geral, comprometendo a minimização dos impactos negativos da distribuição urbana de carga.

Além disso, a situação é agravada pelo fato de que a maioria das medidas e regulamentações propostas tende a ser incoerentes em relação ao contexto atual, no qual a distribuição de cargas está inserida, ao passo que as atividades do transporte urbano vêm sofrendo transformações nos últimos 30 anos, em termos de políticas de entregas (JIT) e das tecnologias utilizadas (DABLANC, 2007).

Felizmente, o foco das autoridades locais vem sofrendo alterações ao longo da última década, tendo em vista a relevância econômica do transporte de carga e importância para o funcionamento dos centros urbanos.

De acordo com Cherrett et al (2012), as autoridades locais de países como França, Alemanha e Bélgica têm demonstrado uma maior preocupação em relação à eficiência e sustentabilidade do transporte urbano de cargas na definição das estratégias e planos para implementação de políticas públicas de forma coordenada tais como pontos de coleta, entregas noturnas, entre outras.

No entanto, tal fato não se observa no Brasil na mesma velocidade, haja vista a falta de prioridade de investimento em infraestrutura para escoamento de mercadorias nos centros, considerando o aumento da frota e circulação de veículos em condições precárias; o atendimento às exigências ambientais; a dificuldade de acesso a esses grandes centros urbanizados; o comércio ilegal e pouco organizado em áreas periféricas; e ainda a existência de regras diferentes pelas cidades para circulação de veículos pesados e sem integração dessas regras entre os municípios (PORTUGAL; MORGADO; LIMA JUNIOR, 2011). 
Além disso, o projeto de lei 12.587/2012 do Ministério das Cidades (2012) apresenta uma política de mobilidade urbana para o País que vem sendo discutida tardiamente desde 2005, porém tal projeto ainda não deixa claro quais são as responsabilidades dos Governos das cidades ao considerar a inserção destas em regiões metropolitanas que apresentam problemas integrados de transporte de carga.

De forma sistêmica, Novaes et al (2004) relaciona a eficiência do processo de distribuição com os interesses e expectativas próprias de seus agentes participantes de uma cadeia de suprimentos e possíveis conflitos que possam prejudicar o desempenho global. Segundo pesquisa apresentada, o processo de distribuição de carga urbana apresenta 6 agentes participantes: Fabricante, Varejista, Transportadora, Comunidade, Autoridades Locais e Fabricantes de Veículos. A seguir, são apresentadas as principais expectativas de cada um desses agentes em relação à eficiência da distribuição urbana de carga:

- Fabricante: o processo se torna eficiente quando não houver perda de produto comercializado, de vendas e/ou de clientes. O seu principal interesse é a permanência no mercado e a manutenção da margem de venda de seus produtos.

- Varejista: a eficiência da distribuição de carga está relacionada com a operação, disponibilidade de funcionários e sistema de controle no recebimento e expedição da carga: restrições de horário de coleta/entrega para evitar o aumento de custos com o pagamento de horas extras aos funcionários, pontualidade do fornecedor, produtos com qualidade e preço acessível e estoques baixos.

- Transportadora: a eficiência está relacionada com preços dos fretes, competitividade e atendimento dos requisitos de qualidade determinados pelos clientes e normas ambientais, congestionamento, restrições de circulação, localização dos clientes, filas e otimização dos processos de carregamento e descarregamento.

- Comunidade: o congestionamento, o aumento da poluição atmosférica e sonora, e o elevado número de acidentes estão entre os principais problemas provocados pela distribuição de cargas. A população demanda que as autoridades locais fiscalizem os veículos de carga quanto à emissão de 
poluentes e ao cumprimento das normas de trânsito: locais de parada, restrições de horário e circulação de veículos.

- Autoridades, os problemas causados pela distribuição de cargas na cidade poderiam ser minimizados pela criação e aplicação de normas e regras específicas para o sistema de transporte de cargas, sem causar impactos econômicos negativos para a cidade.

- Fabricantes de Veículos de Carga, a eficiência está em aumentar as vendas e atender as expectativas da Transportadora e das Autoridades Locais.

Acrescenta-se ainda o papel dos operadores logísticos, que são empresas especializadas na prestação de serviços logísticos. Essas empresas são responsáveis pelo gerenciamento das atividades logísticas dos embarcadores e têm o objetivo de realizar a entrega ao destino final.

Segundo a Associação Brasileira de Movimentação e Logística (ABML) o operador logístico (ou Prestador de Serviço Logístico - PSL) funciona como o fornecedor de serviços logísticos especializados em gerenciar toda ou parte das atividades logísticas de uma cadeia de suprimento, como forma de agregar valor ao produto. Segundo a $A B M L$, o PSL deve prestar serviços, no mínimo nas três atividades básicas: gestão de armazenagem, de estoques e de transportes. Dessas atividades derivam outras, sejam elas:

1. Atividades próprias da administração de materiais e junto à manufatura: coordenação e execução dos pedidos a fornecedores - como rastreamento de veículos, recebimento, conferência física e documental, etc., paletização para movimentação interna e armazenagem, gestão de informações logísticas, apoio à produção, entre outros.

2. Atividades próprias da distribuição física e junto à manufatura: embalagem de produtos acabados ou semiacabados, unitização de carga, preparação para expedição, distribuição direta da fábrica e operações cross docking, transferência para centros de distribuição (CD), consolidação roteirização, entre outros.

3. Atividades da distribuição física junto ao cliente do embarcador: abastecimento de gôndolas, retirada de paletes vazios, entrega de produtos secos ou 
refrigerados e retirada de devoluções, podendo expandir até o consumidor final, como entrega direta do embarcador ao consumidor, no caso de consórcios e serviços de Serviço de Atendimento ao Consumidor final (SAC) e como instalação e troca de produtos.

A essência do papel do operador logístico pode ser definida pelo atendimento das necessidades do embarcador, de forma individualizada e integrada, em termos dos serviços logísticos demandados pela cadeia de suprimentos que ele atua. Desta forma, o operador logístico torna-se o responsável pela gestão das interfaces com os demais agentes da cadeia de suprimentos, embarcador e transportador, de acordo com o escopo e prazos definidos nos contratos de longo ou curto prazo, com foco na efetividade da entrega e eficiência nos processos logísticos (MARRASCO, 2008).

Neste sentido, Lima (2004) descreve o operador logístico como um provedor de serviços logísticos que gerencia e executa de forma coordenada as atividades de transporte, armazenagem, gerenciamento de estoques e atividades relacionadas à informação e até mesmo o gerenciamento da cadeia de suprimentos. Além disso, a autora destaca os seguintes serviços como sendo os mais frequentemente ofertados pelos operadores logísticos: negociação de frete, seleção de transportadora, gerenciamento de frota, consolidação e desconsolidação de carga, gerenciamento de armazém, emissão de pedido, sistema de informações, reposição de estoque e retorno de mercadoria.

Desta forma, os operadores logísticos podem agregar um diferencial competitivo para seus contratantes em termos de redução de investimento em ativos, foco na atividade central do negócio, flexibilidade operacional, custos operacionais e qualidade dos serviços logísticos (LIMA, 2004).

Nesta linha, Stefansson (2006) destaca os papéis e serviços prestados pelos transportadores e operadores logísticos em estudo de caso conduzido com cinco prestadores de serviços logísticos, conforme a seguir:

- Transportadores - responsáveis pelo transporte de carga de um ponto ao outro da cadeia de suprimentos, disponibilizando o produto no tempo e local definidos pelo cliente, pode vir a expandir o escopo de serviços prestados, conforme a sua 
estrutura instalada e capacidade administrativa, podendo até mesmo operar como terminal de croos-docking.

Logo, os serviços comumente prestados pelos transportadores são: coleta, distribuição, entrega ao consumidor final, manuseio de documentação, monitoramento e rastreamento de informações, agendamento de entrega ou coleta e ferramentas de desempenho de entrega.

- Operadores Logísticos - oferecem diversos serviços logísticos além do transporte de carga, podendo atuar como terminal de cross-docking, consolidação, desconsolidação e fracionamento de carga, e picking de produto. Para tanto, não utiliza necessariamente ativos próprios, podendo vir a contratar frota terceirizada para o transporte e distribuição de carga, assim como aluguel de terminais, centros de distribuição e armazenagem.

Sendo assim, Stefansson (2006) classifica os serviços prestados pelos operadores logísticos em serviços relacionados à movimentação física, tais como, transporte e armazenagem, e serviços relacionados à parte administrativa, que serão descritos a seguir:

- Serviços relacionados à movimentação física: seleção e contratação de transportadores, monitoramento e rastreamento da carga em trânsito, recebimento e armazenagem de produtos, embalagem e rotulagem de produtos, montagem de componentes, separação para entrega e retorno de produtos.

- Serviços relacionados à parte administrativa: gestão dos pedidos, gestão de estoques, planejamento de entrega, monitoramento e rastreamento das entregas, atendimento ao cliente, gestão de reclamações de clientes, gestão de risco e pagamentos.

\subsubsection{Canais e estrutura de distribuição urbana de carga}

Segundo Anderson et al (1997), o embarcador pode vir a distribuir seu produto diretamente ao varejo utilizando instalações logísticas e equipes funcionais próprias, 
ou indiretamente por meio de parceiros e prestadores de serviços logísticos (Figura $4)$.

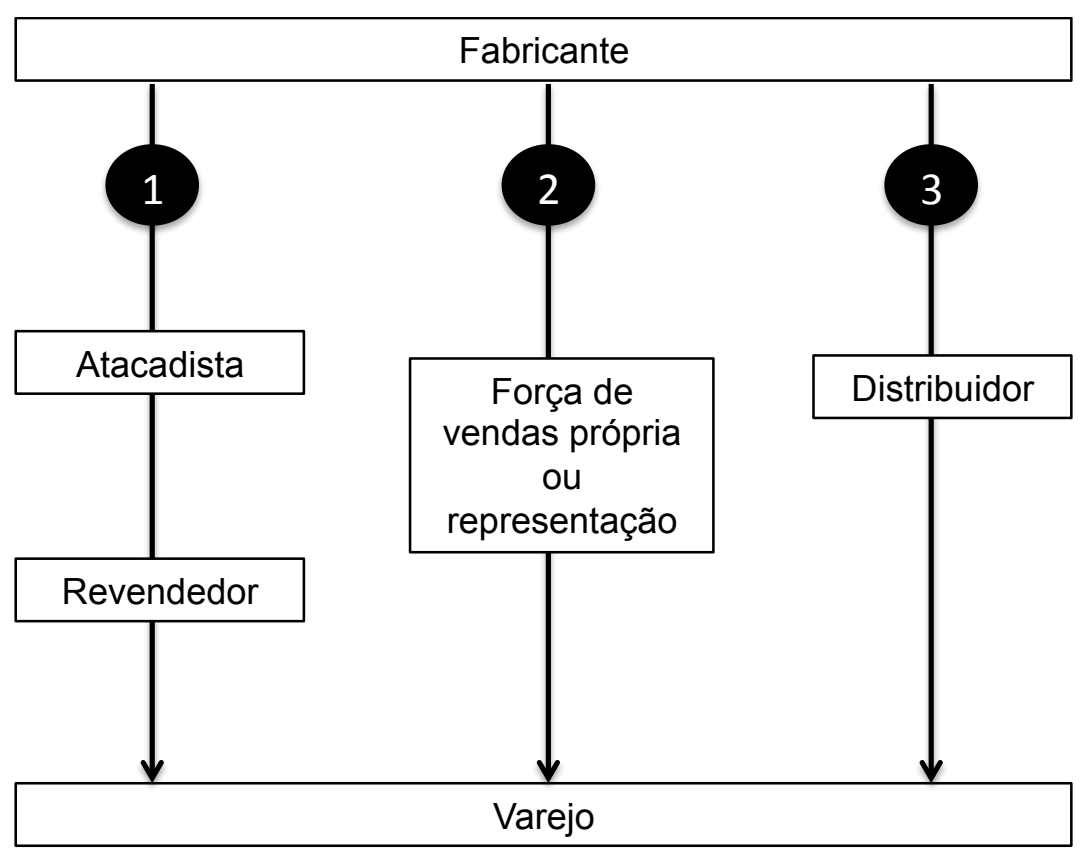

Figura 4 - Canais tradicionais de distribuição

Fonte: Anderson et al (1997, p. 62).

A Figura 4 apresenta três possíveis canais de distribuição de produtos ao varejo. A opção 1 mostra a distribuição de produtos ao varejo por intermédio de atacadista e revendedor, sendo o revendedor responsável pelas atividades de venda e pósvenda, assim como o atendimento de todas as necessidades do cliente relacionadas ao produto, por exemplo: informações, estoques, tamanho do lote, devolução e reposição de mercadoria. No entanto, o embarcador pode vir a ter acesso às expectativas e necessidades dos clientes diretamente (opção 2), ou então, por meio da terceirização dos serviços logísticos e contração de um distribuidor (opção 3).

Blanco e Fransoo (2013) enfatizam que as megacidades localizadas em mercados emergentes possuem canais de distribuição de mercadorias ao varejo com características distintas quando comparados com mercados desenvolvidos, por conta do grande número de pequenos varejos de propriedade familiar que competem no mercado local com as grandes redes varejista, e que respondem por aproximadamente metade do volume de vendas ao varejo.

As características desses canais são distintas e praticamente opostas, conforme apresentado no Quadro 1. 
Quadro 1 - Comparação entre os canais de distribuição

\begin{tabular}{lll}
\hline Funções & Grandes redes varejistas & Pequeno varejo \\
\hline Equipe & Equipe profissional & Proprietário \\
Estrutura logística & CDs, Cross-docks, 3PL & Nenhuma \\
Fluxo financeiro & Crédito e transações bancárias & Dinheiro e crédito pessoal \\
Itens & Caixas (loja) e pallets (CD) & Unidades e caixas mistas \\
Número de SKUs & Milhares a dezenas de milhares & Centenas \\
Categorias & 5 a algumas dezenas & uma ou duas \\
$\begin{array}{l}\text { Número de } \\
\text { consumidores }\end{array}$ & Dezenas de milhares & 100 -200 \\
Tecnologia & ERPs, EDI, scanners & Telefone celular pessoal \\
\hline
\end{tabular}

Fonte: Blanco e Fransoo (2013, p.5).

Por exemplo, conforme indica o Quadro 1, a operação da loja do pequeno varejo é normalmente familiar e sem apoio de equipe ou infraestrutura logística especializada e, por conta disso, o proprietário pode vir a conhecer pessoalmente a maioria dos clientes. As lojas são geralmente pequenas, com pouco espaço para armazenagem e exposição dos produtos, que são comercializados em unidades individuais ou em pequenos pacotes. Como os pagamentos podem ser feitos em dinheiro ou por meio de crédito baseado na relação de confiança estabelecida entre o proprietário e o cliente, o caixa disponível pode não ser suficiente para realizar o pagamento dos fornecedores. Logo, um dos desafios enfrentados pelo pequeno varejo é conciliar a data de entrega do pedido com a disponibilidade de dinheiro em caixa para o pagamento da mercadoria (BLANCO; FRANSOO, 2013).

Além das características distintas mencionadas anteriormente, esses canais também divergem no que diz respeito às atividades essenciais que devem ser consideradas no processo de atendimento ao pequeno varejo e que são apresentadas na Figura 5. 


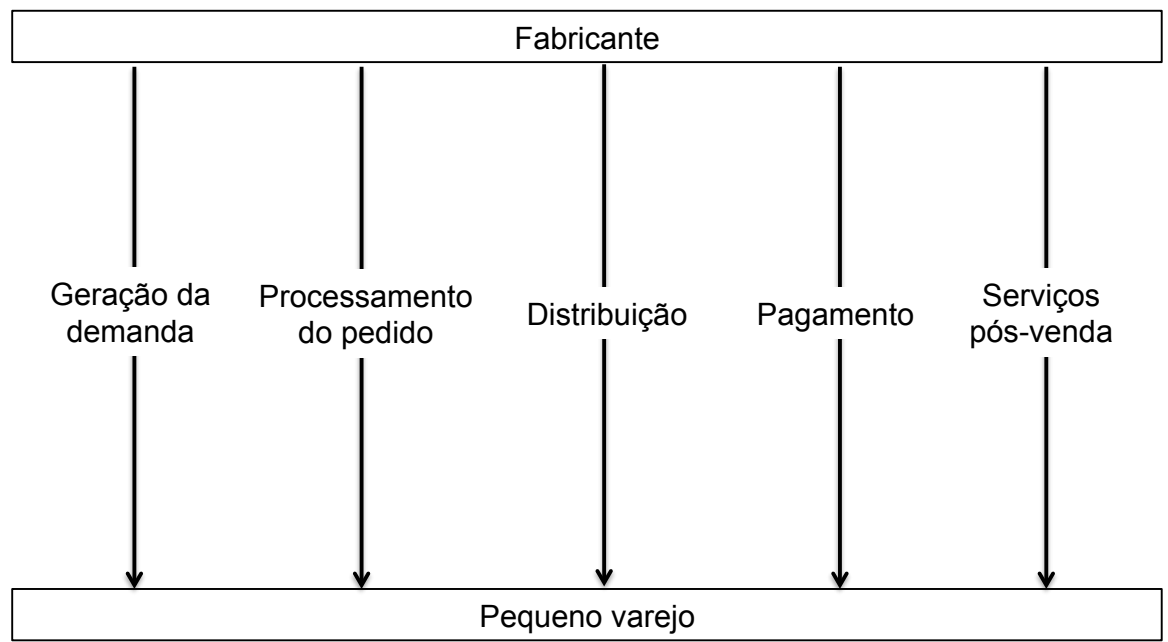

Figura 5 - Atividades- chave no atendimento ao pequeno varejo Fonte: Blanco e Fransoo (2013, p.6).

Normalmente, o atendimento das grandes redes de supermercado é feito de forma coordenada entre diversas áreas do varejo e do fabricante, sendo pautado nos protocolos pré-definidos que definem, por exemplo, as janelas de entrega, o tipo veículo, procedimentos de carga e descarga e formas de pagamento. As informações de demanda são enviadas eletronicamente para o fabricante, que aciona as demais atividades transacionais: processamento do pedido, distribuição, pagamento e pós venda, sendo a eficiência medida com base no desempenho logístico.

No caso do pequeno varejo, as atividades de pré-venda (geração da demanda e processamento do pedido) são realizadas durante visitas ao estabelecimento, o que promove uma maior proximidade pessoal, o levantamento das reais necessidades do cliente, o compartilhamento de responsabilidade na tomada de decisão sobre promoções e possibilita a coordenação remota das atividades de pós-venda. Devido ao alto grau de informalidade do pequeno varejo, o pagamento é geralmente realizado no momento da entrega, ficando a cargo do motorista a responsabilidade pelo recebimento e transporte do dinheiro.

Logo, torna-se fundamental a definição da estratégia de atendimento ao pequeno varejo mais adequada, conforme as possíveis configurações apresentadas na Figura 6. 


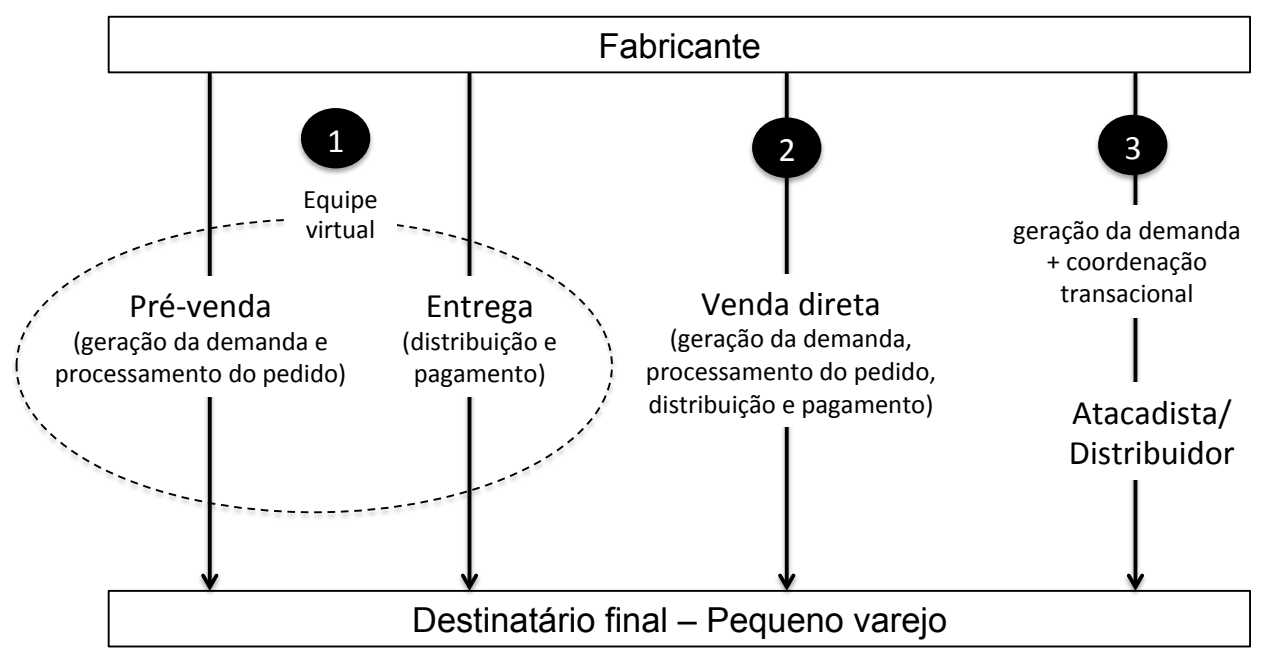

Figura 6 - Estratégias de atendimento: canal direto $x$ canal indireto Fonte: Blanco e Fransoo (2013, p.8).

A Figura 6 resume as opções que o embarcador pode adotar como canal de distribuição dos seus produtos aos diversos pontos de venda do pequeno varejo. A distribuição pode ser realizada de forma indireta (opção 3), priorizando o desempenho logístico em detrimento do relacionamento pessoal, ou de forma direta (opções 1 e 2), o que requer uma maior complexidade na gestão integrada do estoque, portfólio de produto e fluxo de caixa.

Para oferecer um atendimento ao cliente com o melhor nível de serviço a um menor custo, as empresas procuram adotar estratégias para movimentação da carga completa (Full Truckload - FTL) ou fracionada (less than a full truckload - LTL), desde a origem ao destino. Essas estratégias incluem na maioria das vezes, a localização estratégica de centros de distribuição (CD) que servem como consolidação, fracionamento de carga ou transit point (como fluxo direto e indireto) (TACLA et al., 2006), cross-docking e combinação ou merge in transit (entre a produção e o transporte ao destino final) (MCKINNON, 2009).

Segundo Ribeiro et al. (2006), essas estratégias de distribuição também podem adotar instalações intermediárias de armazenagem, como terminais de despacho, que permitem o rápido fluxo de produtos puxados pelo cliente, por meio de ordens de pedido, ou seja, postergando o envio de produtos aos CDs até a confirmação de demanda real. Segundo os autores, esses produtos geralmente têm as seguintes características: alto valor agregado, alta amplitude de previsão de vendas, alta demanda e com alto grau de obsolescência. 
A estrutura para distribuição de bens de consumo ao varejo em economias emergentes (SANCHES JUNIOR, 2008) especificamente no caso do Brasil, tem estrutura logística diferente quando comparada com economias da Europa (BESTUFS ou BEST Urban Freight Solution) e América do Norte. Nestes países, adotou-se a representação de plataformas logísticas, geralmente, no entorno das cidades ou nos portos, no intuito de otimizar recursos e infraestruturas (objetivos comuns em uma área delimitada) (DUTRA, 2004, p.85). Apesar de muitos países europeus adotarem medidas restritivas antiquadas para acesso de veículos de carga aos grandes centros, existem serviços de entrega realizados por empresas de postagem tradicional, pontos automatizados para recebimento de mercadoria, uso de veículos equipados com GPS e com otimizadores de rotas, empresas que alugam espaço no centro urbano para armazenar mercadorias de residentes e até do varejo (DABLANC, 2007).

No caso do Brasil, a estrutura de distribuição em grandes centros urbanos se restringe à localização de terminais de carga próximo a esses centros (CARRARA, 2007; CORREIA; OLIVEIRA; GUERRA, 2012; OLIVEIRA et al., 2012; OLIVEIRA; NUNES; NOVAES, 2010; PORTUGAL; MORGADO; LIMA JUNIOR, 2011); distribuição de carga em veículos leves e VUC (Veículo Urbanos de Carga) com capacidade de até 1,5t e comprimento de até 6,3 metros (TACLA et al., 2006; GATTI JUNIOR, 2011); entregas noturnas nas megacidades de Belo Horizonte, Rio de Janeiro e São Paulo (OLIVEIRA; BRAGA; ABREU, 2010).

Essa estrutura de distribuição gera desafios às empresas no tocante ao atendimento do nível de serviço logístico (OLIVEIRA; NUNES; NOVAES, 2010), ao Governo que procura manter investimento em infraestrutura urbana, tanto para manutenção e construção de transporte público, moradia, espaço para estabelecimento de estrutura física para o comércio e indústria em geral, quanto para o acesso ao comércio varejista pelas empresas e cidadãos por meio de vias públicas.

Essa complexidade se agrava quando o objeto de investigação são as megacidades. Por outro lado, existem projetos para construção de mini-terminais de carga para distribuição na cidade de São Paulo (SANCHES JUNIOR, 2008, p.154). Contudo, esses projetos não refletem a realidade brasileira e as pesquisas a respeito de 
iniciativas de distribuição de carga urbana no Brasil ainda são incipientes (OLIVEIRA; NUNES; NOVAES, 2010; SANCHES JUNIOR, 2008; p.41).

Em se tratando de sustentabilidade, o aumento da cobrança da sociedade em relação aos aspectos sociais e ambientais tem gerado diversas mudanças, nos últimos anos, no transporte de carga com menor emissão de GEE, menor espaço disponível nos grandes centros para movimentação e descarga de mercadorias, aumentando as áreas de lazer e preocupação com a qualidade de vida.

De maneira genérica, a distribuição de carga engloba várias etapas dentro do sistema de movimentação, com distintas atividades e responsabilidades. A Figura 7 mostra um tradicional fluxo de movimentação de carga (atividades) no Brasil, desde a origem ao destino, assim como um esboço da participação dos agentes (participantes), em cada etapa, dentro do contexto da city logistics.

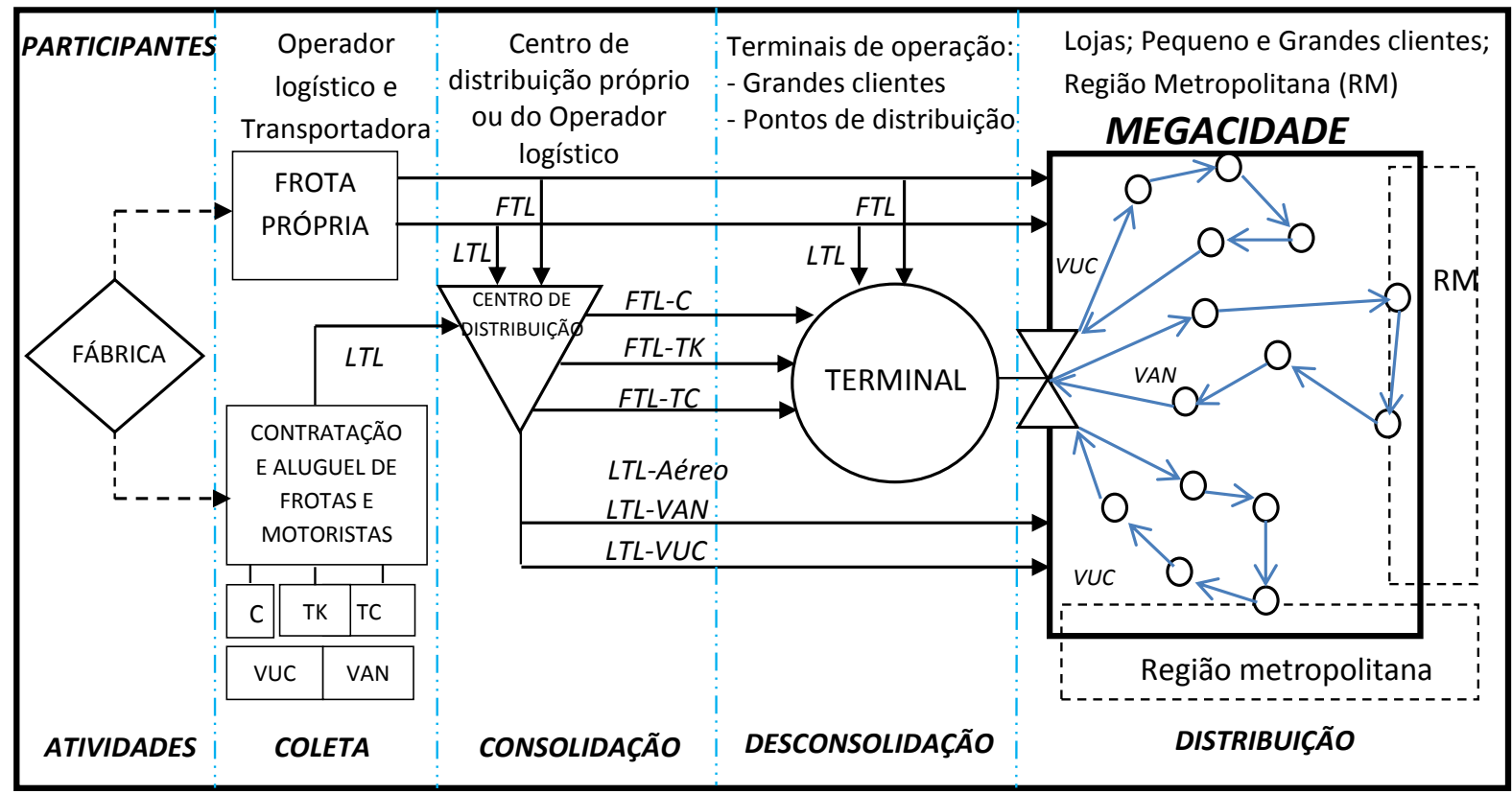

CARRETA: C, TRUCK: TK, TOCO: TC

$\triangle D E C I S A ̃ O ~ \nabla A R M A Z E N G E M \quad$ OOPERAÇAO $\rightarrow$ TRANSPORTE

Figura 7 - Esquema da distribuição de carga em megacidades brasileiras Fonte: Vieira et al. (2013, p.7)

Portanto, como descrito por Benjelloun e Crainic (2009), conhecer a estrutura de distribuição de carga, assim como o papel dos participantes nas atividades de coleta, consolidação, desconsolidação e distribuição, é fundamental para o melhor entendimento dos aspectos relacionados à distribuição urbana de carga, ou seja, dos atributos de distribuição. 
Logo, pode-se ressaltar a contribuição do operador logístico na estrutura de distribuição urbana de carga apresentada na Figura 7, por meio da prestação de serviços logísticos relacionados ao gerenciamento da armazenagem, distribuição e transporte, e cujo foco está na eficiência logística desafiada cada vez mais pelas entregas fracionadas, com maior frequência e em lugares de difícil acesso e, para tanto, pode vir a fornecer feedbacks à cadeia de suprimentos que visam o estabelecimento de ações conjuntas para um melhor desempenho global. Esses são exemplos de medidas colaborativas que podem ser adotadas por dois ou mais agentes participantes da distribuição urbana de carga e que serão descritas no próximo tópico

\subsubsection{Colaboração logística}

Colaboração logística é o primeiro grupo de "atributos de distribuição de carga" que será apresentado. Na realidade, o tema é importante também sob o ponto de vista dos papéis que cada agende desempenha no canal de distribuição. Portanto, justifica-se a sua apresentação nesta seção.

"A colaboração está intimamente relacionada à forma como as empresas compartilham informações, realizam ações conjuntas e intensificam relações interpessoais." (VIEIRA; YOSHIZAKI; LUSTOSA, 2010)

Quanto maior a busca por geração de valor dos integrantes de uma GCS, maior será a colaboração entre eles, uma vez que a permanência de uma empresa no mercado competitivo é ameaçada pela ineficiência em qualquer etapa do processo, dado que o resultado de toda cadeia pode ser comprometido (CAVENAGHI, 2011).

Neste sentido, Tacla (2010), em seu estudo sobre os aspectos fundamentais para a formação do custo para o transporte rodoviário de carga, enfatiza que o caminho sustentável para a melhoria do desempenho do sistema logístico é o aumento da produtividade a partir da eliminação ou redução das ineficiências de transporte. $O$ autor destaca os seguintes problemas enfrentados no transporte rodoviário de carga que impactam diretamente no custo da operação: 
- Filas para carga e descarga.

- Roteirização inadequada.

- Deficiência estrutural das estradas

- Congestionamentos.

- Planejamento de compras e vendas.

- Assimetria de informação no planejamento de compras, vendas, produção e logística e consequente planejamento de carga deficitário.

Logo, as ações conjuntas recomendadas para melhorar a produtividade do transporte de carga rodoviário e redução direta dos custos devem priorizar a redução nos tempos de carga/descarga/trânsito, a eficiência na ocupação do veículo e, principalmente, o transporte colaborativo, ou seja, a colaboração entre os agentes envolvidos no planejamento integrado da consolidação de carga pautado no compartilhamento de informações e ganhos. (TACLA, 2010).

Segundo Vieira, Yoshizaki e Lee (2009b), a capacidade de medir o desempenho logístico dos agentes em um elo da cadeia, o entendimento das suas rotinas e transações são determinantes para que a análise do nível de colaboração se torne viável. Neste sentido, os autores apresentam aspectos de colaboração agrupados em elementos de integração estratégica, tática e pessoal. O Quadro 2 destaca alguns desses aspectos de colaboração logística, e que podem vir a contribuir para uma melhor eficiência logística dos envolvidos.

Quadro 2 - Aspectos de colaboração logística

\begin{tabular}{ll}
\hline Nível & Aspectos de colaboração \\
\hline Integração & Compartilhamento de informações de estoque, metas e planos logísticos. \\
& Conhecimento das dificuldades logísticas e estratégias do parceiro. \\
& Envolvimento da alta gerência na definição dos acordos logísticos. \\
Integração & $\begin{array}{l}\text { Interação entre as áreas funcionais das empresas. } \\
\text { tática }\end{array}$ \\
& Trunspes dedicadas no atendimento aos processos logísticos do parceiro. \\
& e resolução de anomalias. \\
& Padronização e documentação de processos logísticos. \\
& Participação de parceiros logísticos nos projetos de melhoria. \\
& Compartilhamento de custos e ganhos logístico. \\
Integração & Agenda de reuniões entre as equipes funcionais. \\
interpessoal & Aspectos comportamentais e de clima organizacional das empresas. \\
& Relações de confiança, reciprocidade, flexibilidade e interdependência.
\end{tabular}


Vivaldini e Pires (2012) enfatizam que a colaboração requer um alto nível de troca de informações, confiança e compromisso na interação entre as empresas. Esses elementos buscam fortalecer o negócio e são fundamentais para estabelecer um relacionamento colaborativo no qual duas ou mais empresas compartilham as responsabilidades, trabalham em parceria e dividem os resultados da cadeia de suprimentos. Desta forma, os autores apresentam os seguintes fatores que favorecem a colaboração:

- Compartilhamento de ganhos

- Transparência dos resultados

- Políticas integradas, objetivos e metas comuns.

- Alinhamento de recursos

- Comunicação transparente

- Compartilhamento de informações

- Planejamento de soluções em conjunto

\subsection{ATRIBUTOS DA DISTRIBUIÇÃO DE CARGA}

Este tópico tem por objetivo destacar os atributos encontrados em pesquisas relevantes sobre o tema distribuição urbana de carga. Nessas pesquisas, os autores apresentam os atributos como sinônimos de: elementos, aspectos, fatores, características, parâmetros, critérios ou iniciativas. No entanto, todas essas denominações podem ser vistas e avaliadas pelos mesmos agentes, seja este uma empresa, o governo, o cliente ou usuário.

\subsubsection{Atributos - Allen et al. (2000)}

Allen et al. (2000) apresentam no seu estudo uma série de elementos que podem dificultar a distribuição de cargas em centros urbanos. A seguir, são destacados alguns exemplos, classificados em: 
- Aspectos governamentais ou regulatórios: restrição de circulação de veículo de cargas em determinados locais e horários ou por tamanho do veículo, restrição de horário para carga e descarga nas vias, estacionamento de veículo de passeio em vaga para carga e descarga, estacionamento em fila dupla e obstrução do tráfico por veículos de carga e passeio.

- Aspectos gerais relacionados a operação logística: definição de janelas de recebimento de mercadoria, frequência de entrega influenciada pela política de estoque pautada em alto giro de estoque e pedido com pequenos volumes, retorno de mercadoria causado por divergência entre pedido e Nota fiscal ou falta de pessoal responsável para recebimento, congestionamento, filas e tempo de permanência no cliente durante o processo de carga e descarga influenciam o número de viagens diárias e de veículos de entrega.

- Aspectos ambientais: adequação à legislação de emissão de gases poluentes e de efeito estufa, tipo de combustível utilizado.

\subsubsection{Atributos - Ljungberg e Gebresenbet (2005)}

Da mesma forma, o estudo realizado por Ljungberg e Gebresenbet (2005) na cidade de Uppsala, na Suécia, revelou as ineficiências do sistema de entrega, que apresenta uma alta frequência de entrega de pequenas mercadorias, envolvendo um grande número de transportadoras e operadores logísticos com baixa eficiência na ocupação do veículo de entrega. Na sequencia, são relacionados os principais aspectos gerais do sistema de entrega analisado:

- Uso ineficiente dos veículos de entrega: alta frequência de paradas e pequenas entregas.

- Baixa utilização da capacidade total do veículo identificada no momento da entrega.

- Elevado número de transportadores e operadores logísticos envolvidos no processo de entrega.

- Falta de regularidade de horário de entrega e adequação ao horário ideal de recebimento para o varejista. 
- Grandes variações no tempo necessário para a entrega das mercadorias, não decorrentes dos volumes entregues.

- Filas frequentes na área de carregamento, impactando negativamente a eficiência global do processo tanto para o varejista quanto para o operador logístico.

\subsubsection{Atributos - Cherrett et al. (2012)}

Em estudo conduzido por Cherrett et al. (2012), no qual foram analisadas 30 pesquisas sobre as atividades do transporte urbano no abastecimento do mercado varejista, sendo a sua maioria conduzida no Sul do Reino Unido, são apresentados fatores que impactam a distribuição em centros urbanos de mercadorias essenciais por tipo de negócio ou estabelecimento.

- Taxa média de entrega por semana: estudo sugere uma média de 7,6 entregas por semana como um dado estatístico para planejamento do tráfego de veículos de entrega nos centros urbanos.

- Número de veículos de entrega por tipo de estabelecimento: o estudo apresenta os estabelecimentos do varejo que comercializam bebidas e comidas e também lojas de sapatos, como os que possuem a maior taxa de entregas, 7 entregas em média na semana.

- Taxa de entrega por tipo de cadeia de abastecimento: o estudo sugere que estabelecimento que possuem um sistema de abastecimento descentralizado, ou seja, que recebem suas mercadorias de diferentes pontos de origem, apresentam as maiores taxas de entrega semanal quando comparados com estabelecimentos com sistema centralizado de abastecimento, por exemplo, um centro de distribuição.

- Agendamento de entrega: as entregas não programadas ocorrem em estabelecimento de menor porte, sendo por conta da política de estoque, com baixo giro de estoque, ou das características da mercadoria, por exemplo, produtos perecíveis. 
Cherrett et al. (2012) também apresentam alguns estudos relacionados com as características da entrega de mercadoria e o planejamento do transporte, tais como: janela de entrega, entrega por dia da semana, sazonalidade anual, tipo de veículo de entrega utilizado, veículos de entrega utilizados na coleta de materiais recicláveis ou devoluções de mercadorias, tempo de permanência durante o carregamento e/ou descarregamento, características da área para carregamento e/ou descarregamento.

\subsubsection{Atributos - Sanches Junior (2008)}

Saches Junior (2008) sugere a utilização de varáveis como base para a criação de indicadores de desempenho logístico na distribuição urbana de carga, que podem auxiliar no planejamento de medidas que visam reduzir o número de viagens por caminhão e minimizar as externalidades da distribuição de carga, e além disso, avaliar os impactos gerados por soluções logísticas em geral. A seguir, as categorias e suas variáveis:

- Variáveis do uso do solo: tipo de imóvel e área ocupada.

- Característica da carga urbana: tipo e peso do produto, volume, frequência e horário de carga e/ou descarga.

- Infraestrutura para carga e descarga: número de vagas para carga e/ou descarga, informações sobre o trânsito na cidade.

- Veículo de carga: tipo e idade do veículo, tipo de computador de bordo, tecnologia de carga/descarga, distância percorrida, número de paradas, tipo de combustível, consumo médio de combustível por veículo, tempo gasto nas atividades de carga e descarga e duração das viagens.

- Meio ambiente: nível de ruído emitido nas atividades logísticas, tipo e quantidade de poluentes emitidos.

- Segurança: Tipo, quantidade e local de acidentes. 


\subsubsection{Atributos - Anand et al. (2012)}

Em seu estudo, Anand et al. (2012) fazem uma revisão da literatura sobre modelagens adotadas no transporte de mercadorias, assim como as tendências em pesquisas sobre modelagem sob a ótica de "city logistics". Desta forma, o estudo analisa os agentes envolvidos (Embarcador, Transportador, Administrador, Cliente), o objetivo e critérios definidos na modelagem. A seguir, são apresentados os objetivos classificados em cinco categorias e alguns critérios adotados nas modelagens levantados no estudo:

- Econômico: origem da carga.

- Eficiência: custo do transporte, rotas, fator de carga, emissão de $\mathrm{CO} 2$, fluxo do produto e do tráfego.

- Segurança nas vias: custo do transporte.

- Meio ambiente: nível de poluição, fator de carga, emissão de CO2, fluxo do trafego e origem da rota.

- Infraestrutura e gestão: localização, ocupação do solo, fluxo do produto e do tráfego.

\subsubsection{Atributos - Browne et al. (2012)}

O estudo realizado pelos autores aborda os aspectos do transporte de carga que resultam em impactos negativos ao meio ambiente e a economia das cidades, tais como: congestionamento, poluição sonora e acidentes no trânsito. Além disso, em uma escala global, o sistema de distribuição contribui para as mudanças climáticas que têm ocorrido no planeta, através da emissão de gases de efeito estufa. Neste sentido, os autores classificam uma série de iniciativas, associadas à determinados aspectos do transporte de carga, que podem contribuir para mudar este cenário. Algumas dessas iniciativas são apresentadas a seguir: 
- Quilometragem total por veículo/viagem: consolidação de carga, frequência de pedido e entrega, informações sobre condições do tráfego e regulamentação de vagas para estacionamento.

- Consumo de combustível por veículo: comportamento e atitude do motorista, tipo do veículo e motor, uso de veículos que utilizem energias renováveis e não fósseis e adição de uma parcela de biocombustível nos combustíveis derivados de petróleo.

- Emissão de poluição por veículo: definição de zonas de baixa emissão e emprego de filtros de poluentes nos veículos.

- Nível de ruído por rota: restrição de circulação por zona e tipo de veículo, tipo de veículo utilizado e comportamento e atitude do motorista.

- Número de acidente por veículo: comportamento e atitude do motorista e tipo de veículo utilizado e de dispositivo visual (espelhos retrovisores).

\subsubsection{Atributos - Moreira (2012)}

Moreira (2012), em sua pesquisa realizada na Região Metropolitana de Minas Gerais sobre os principais problemas logísticos relacionados às operações de coleta, armazenagem e distribuição de cargas na região, identificou uma maior incidência de que os problemas durante as atividades de carga e descarga realizadas na região central da cidade. A seguir, com base nos questionários aplicados, são classificados os atributos utilizados no levantamento de dados da pesquisa:

- Características da operação de transporte: frequência de entrega, local para carga e descarga nas vias publicas, número de viagens, conferência de carga no recebimento, origem e destino da carga, tipo de produto transportado, adoção de sistemas de monitoramento de carga, quantidade e tipo de veículos utilizados na operação, prazo de entrega, janelas de entregas definidas pelos clientes, frota própria ou de terceiros, contratação de operador logístico.

- Características da armazenagem: instalações próprias ou de terceiros.

- Problemas enfrentados no recebimento e despacho de cargas: falta de local disponível para carga e descarga, não cumprimento do prazo de entrega, carga 
danificada, roubo de carga, preço elevado do frete, divergência entre nota-fiscal e pedido, veiculo inadequado

- Problemas enfrentados no transporte de cargas: viagem de retorno com caminhão vazio, elevado custo do seguro e frete, demora na carga e descarga, congestionamentos e atrasos na entrega, falta de regulamentação do local de carga e descarga, local de carga e descarga indisponível ou distante do local de entrega, baixa eficiência e ocupação do veículo.

- Problemas enfrentados no armazenamento de cargas: tamanho ou instalações inadequadas, falta de segurança contra incêndio, perda e/ou extravio de carga, localização distante dos clientes e/ou fornecedores, falta de equipamento adequado e mão de obra não qualificada.

- Problemas relacionados à regulamentações de transporte de carga: utilização de diferentes tipos de veículos por conta de restrições de circulação por horário e tipo de veículo, perda de produtividade e aumento dos custos operacionais, alterações nos turnos de trabalho e dificuldade no atendimento das janelas de entrega.

\subsubsection{Atributos - Dablanc (1997)}

Dablanc (1997), em seu estudo realizado em Nova lorque, Paris e em algumas cidades no norte da Europa, analisa as políticas públicas sobre o tema logística urbana e o papel do governo no transporte urbano de carga. A autora destaca alguns aspectos que podem contribuir para um desempenho do transporte urbano de carga mais eficiente, mas que, no entanto, contrariam as práticas logísticas adotadas na cadeia de suprimentos. Os principais aspectos são apresentados a seguir:

1 Diminuição dos tempos de entrega e possibilidade de entrega noturna.

2 Diminuição de entregas em fila dupla.

3 Diminuição de entregas em vias públicas e, consequentemente, da possibilidade de roubo de carga que esta prática pode ocasionar.

4 Melhor consolidação de carga com maiores taxas de ocupação do veículo. 
5 Diminuição das distâncias percorridas entre os pontos de abastecimento, comercial e de consumo final.

6 Otimização do roteiro de entregas.

\subsubsection{Síntese dos atributos levantados na revisão de literatura}

A seguir, apresenta-se a síntese dos atributos da distribuição urbana de carga (Quadro 3), relacionados às operações de coleta, armazenagem, consolidação e distribuição, levantados na revisão de literatura realizada neste trabalho, que neste trabalho são classificados em:

- Atributos logísticos: aspectos relacionados ao transporte e entrega do produto, associados às atividades realizadas no recebimento, estocagem, embarque, expedição, controladoria e transporte.

- Atributos de colaboração: aspectos relacionados à forma como as empresas estabelecem suas relações interpessoais, compartilham informações na gestão da cadeia de suprimentos e definem ações de melhoria em conjunto, buscando o fortalecimento do negócio.

- Atributos regulatórios: aspectos governamentais do transporte urbano de carga estabelecidos nas políticas públicas, normas e restrições de circulação de veículos de carga.

- Atributos ambientais: práticas adotadas pelas empresas para visando minimizar os impactos ambientais que a distribuição urbana de carga pode vir a causar ao meio ambiente e à comunidade.

- Atributos de risco: aspectos relacionados ao contexto urbano que podem vir a comprometer negativamente a distribuição urbana de carga ou, até mesmo, inviabilizar a entrega efetiva da carga. 
Quadro 3 - Síntese dos atributos da revisão de literatura

\begin{tabular}{|c|c|c|c|c|c|c|c|c|c|c|c|c|c|c|c|c|c|}
\hline & $\begin{array}{l}\text { তิ } \\
\text { D } \\
\stackrel{5}{=} \\
\frac{c}{0} \\
\frac{0}{0} \\
0\end{array}$ & 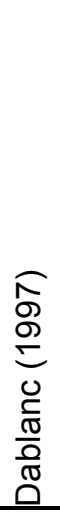 & 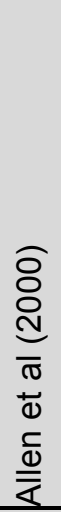 & 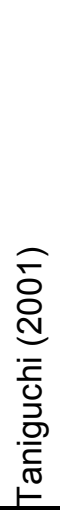 & 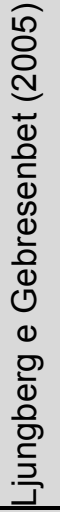 & 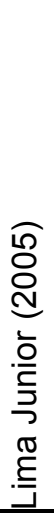 & 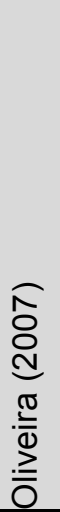 & 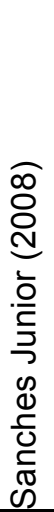 & 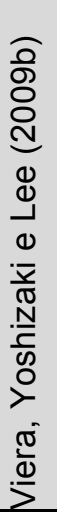 & 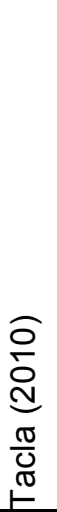 & 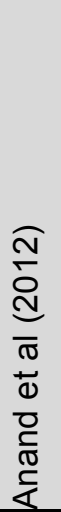 & 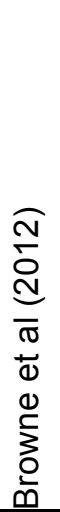 & 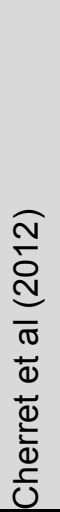 & 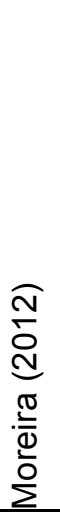 & 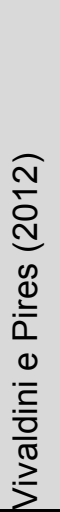 & 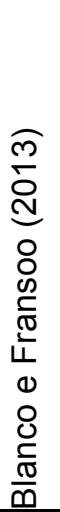 & 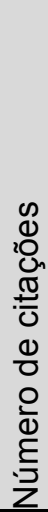 \\
\hline $\begin{array}{l}\text { I. ATRIBUTOS } \\
\text { LOGÍSTICOS }\end{array}$ & & & & & & & & & & & & & & & & & \\
\hline $\begin{array}{l}\text { capacidade do } \\
\text { veículo }\end{array}$ & & & & & $x$ & & & & & & & & & & & & 1 \\
\hline $\begin{array}{l}\text { característica da } \\
\text { carga }\end{array}$ & & & & & & & & $x$ & & & & & & & & $x$ & 2 \\
\hline computador de bordo & & & & & & & & $x$ & & & & & & & & & 1 \\
\hline conferência de carga & & & & & & & & & & & & & & $x$ & & & 1 \\
\hline $\begin{array}{l}\text { conformidade na } \\
\text { documentação }\end{array}$ & & & & & & & & & & & & & & $x$ & & & 1 \\
\hline $\begin{array}{l}\text { consumo de } \\
\text { combustível }\end{array}$ & & & & $x$ & & & & $\mathrm{x}$ & & & & & & & & & 2 \\
\hline consumo sazonal & & & & & & & & & & & & & $x$ & & & & 1 \\
\hline custo do transporte & & & & & & & & & & $x$ & $x$ & & & $x$ & & & 3 \\
\hline destino da carga & & & & & & & & & & & & & & $x$ & & & 1 \\
\hline distância percorrida & & & $x$ & & & & & $x$ & & & & & & & & & 2 \\
\hline $\begin{array}{l}\text { divergência entre } \\
\text { pedido e NF }\end{array}$ & & & $x$ & & & & & & & & & & & $x$ & & & 2 \\
\hline $\begin{array}{l}\text { equipamentos para } \\
\text { carga e descarga }\end{array}$ & & & & & & & & $x$ & & & & & & & & & 1 \\
\hline $\begin{array}{l}\text { falta de pessoal para } \\
\text { recebimento }\end{array}$ & & & $x$ & & & & & & & & & & & & & & 1 \\
\hline filas & & & $x$ & & $x$ & $x$ & & & & & & & & & & & 3 \\
\hline frequência de entrega & & & $x$ & & $x$ & & & $x$ & & & & $\mathrm{x}$ & $x$ & $x$ & & & 6 \\
\hline frequência de pedido & & & & & & & & & & & & $x$ & & & & & 1 \\
\hline $\begin{array}{l}\text { frota própria ou } \\
\text { terceiros }\end{array}$ & & & & & & & & & & & & & & $\mathrm{x}$ & & & 1 \\
\hline giro de estoque & & & & & & $x$ & & & & & & & & & & & 1 \\
\hline idade do veículo & & & & & & & & $x$ & & & & & & & & & 1 \\
\hline $\begin{array}{l}\text { informações de } \\
\text { trânsito }\end{array}$ & & & & & & & & $\mathrm{x}$ & & & & & & & & & 1 \\
\hline infraestrutura viária & $x$ & & & & & & & & & & & & & & & & 1 \\
\hline janela de entrega & & & $x$ & & $x$ & $x$ & $x$ & $x$ & & & & & $x$ & $x$ & & & 7 \\
\hline local para carga & $x$ & $x$ & & & $x$ & & & & & & & & & $x$ & & & 4 \\
\hline local para descarga & $x$ & $x$ & & & $x$ & & & & & & & & & $x$ & & & 4 \\
\hline localização & & & & & & & & & & & $x$ & & & & & & 1 \\
\hline $\begin{array}{l}\text { monitoramento da } \\
\text { carga }\end{array}$ & & & & & & & & & & & & & & $x$ & & & 1 \\
\hline
\end{tabular}




\begin{tabular}{|c|c|c|c|c|c|c|c|c|c|c|c|c|c|c|c|c|c|}
\hline & 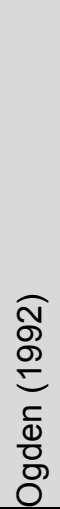 & $\begin{array}{l}\text { న } \\
\text { ब } \\
\pm \\
0 \\
\frac{0}{0} \\
\frac{0}{0} \\
0\end{array}$ & 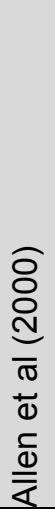 & 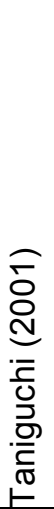 & 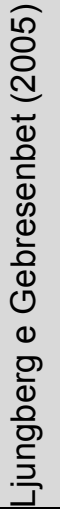 & 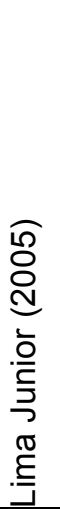 & 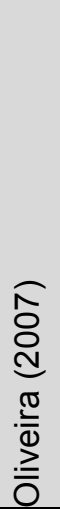 & 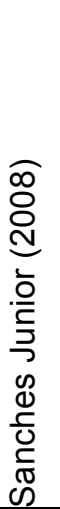 & 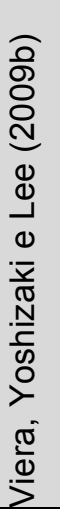 & 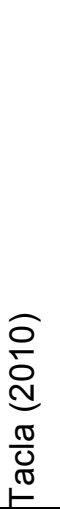 & 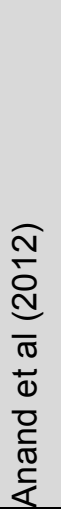 & 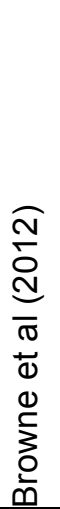 & 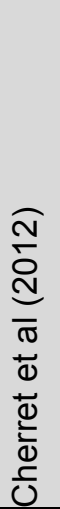 & 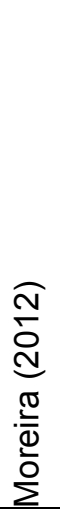 & 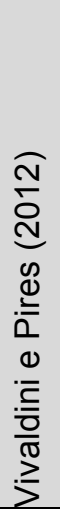 & 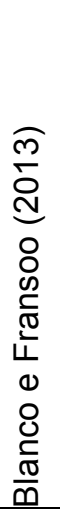 & 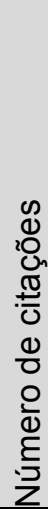 \\
\hline $\begin{array}{l}\text { número de } \\
\text { fornecedores }\end{array}$ & & & & & $x$ & & & & & & & & & & & & 1 \\
\hline $\begin{array}{l}\text { número de vagas } \\
\text { para carga }\end{array}$ & & & & & & & & $x$ & & & & & & & & & 1 \\
\hline número de veículos & & & $x$ & & $x$ & & & & & & & & $x$ & $x$ & & & 4 \\
\hline número de viagens & & & $x$ & & $x$ & & $x$ & $x$ & & & & & & $\mathrm{x}$ & & & 5 \\
\hline $\begin{array}{l}\text { ocupação do solo e } \\
\text { estrutura das vias }\end{array}$ & & & & & & & & & & $\mathrm{x}$ & $x$ & & & & & & 2 \\
\hline ocupação do veículo & & $x$ & $x$ & & $x$ & & & & & $x$ & $x$ & & & & & & 5 \\
\hline origem da carga & & & & & & & & & & & $x$ & & & $x$ & & & 2 \\
\hline política de estoque & & & $x$ & & & & & & & & & & & & & & 1 \\
\hline prazo de entrega & & & & & & & & & & & & & & $x$ & & & 1 \\
\hline $\begin{array}{l}\text { qualificação da mão } \\
\text { de obra }\end{array}$ & & & & & & & & & & & & & & $\mathrm{x}$ & & & 1 \\
\hline quantidade entregue & & & $x$ & & $x$ & $x$ & & $x$ & & & & & & & & & 4 \\
\hline retorno de mercadoria & & & $x$ & & & & $x$ & & & & & & & & & & 2 \\
\hline roteirização & & & & & & & & & & $x$ & $x$ & & & & & & 2 \\
\hline tamanho do pedido & & & $x$ & & & $x$ & & & & & & & & & & & 2 \\
\hline $\begin{array}{l}\text { tecnologias } \\
(\text { ERP,EDI,WMS ...) }\end{array}$ & & & & & & & & & & & & & & & & $x$ & 1 \\
\hline $\begin{array}{l}\text { tempo de carga e } \\
\text { descarga }\end{array}$ & & $x$ & $x$ & & $x$ & $x$ & & & & $x$ & & & $\mathrm{x}$ & & & & 6 \\
\hline tempo de viagem & & $x$ & & & & & & $x$ & & $x$ & & & & & & & 3 \\
\hline tipo de veículo & & & & & & & & $x$ & & & & $x$ & & $x$ & & & 3 \\
\hline $\begin{array}{l}\text { viagem de retorno } \\
\text { sem carga }\end{array}$ & & & & & & & & & & & & & & $\mathrm{x}$ & & & 1 \\
\hline $\begin{array}{l}\text { II. ATRIBUTOS DE } \\
\text { COLABORAÇÃO }\end{array}$ & & & & & & & & & & & & & & & & & 0 \\
\hline acordos logísticos & & & & & & & & & $x$ & & & & & & $x$ & & 2 \\
\hline $\begin{array}{l}\text { agenda única entre } \\
\text { equipes } \\
\text { multifuncionais }\end{array}$ & & & & & & & & & $x$ & & & & & & & & 1 \\
\hline $\begin{array}{l}\text { aspectos } \\
\text { comportamentais e } \\
\text { clima organizacional }\end{array}$ & & & & & & & & & $x$ & & & & & & & & 1 \\
\hline $\begin{array}{l}\text { compartilhamento de } \\
\text { custos e ganhos }\end{array}$ & & & & & & & & & $x$ & $x$ & & & & & $x$ & & 3 \\
\hline $\begin{array}{l}\text { compartilhamento de } \\
\text { informações }\end{array}$ & & & & & & & & & $X$ & $x$ & & & & & $x$ & & 3 \\
\hline compartilhamento de & & & & & & & & & $x$ & & & & & & & & 1 \\
\hline
\end{tabular}




\begin{tabular}{|c|c|c|c|c|c|c|c|c|c|c|c|c|c|c|c|c|c|}
\hline & $\begin{array}{l}\text { ত̃ } \\
\text { ু } \\
\stackrel{5}{=} \\
\frac{c}{0} \\
\frac{0}{0} \\
0\end{array}$ & 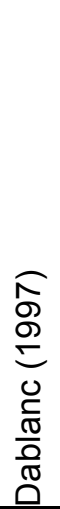 & 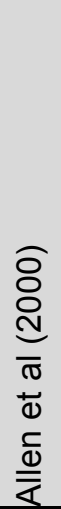 & 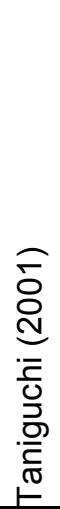 & 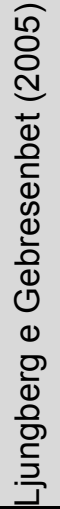 & 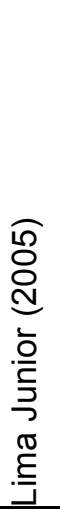 & 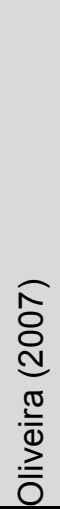 & 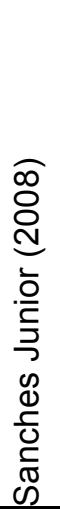 & 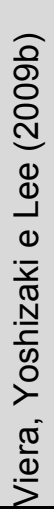 & 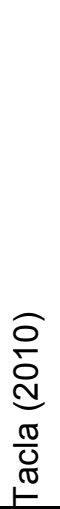 & 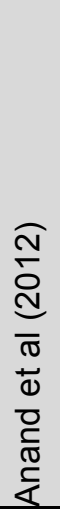 & 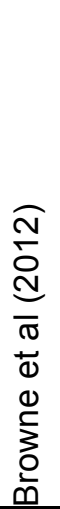 & 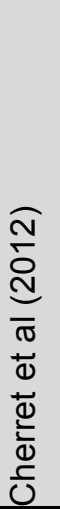 & 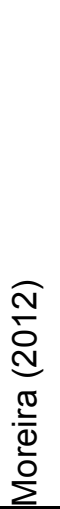 & 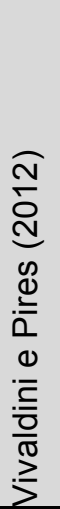 & 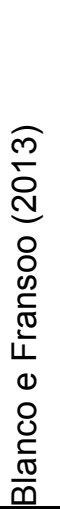 & 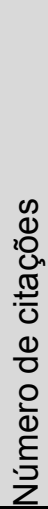 \\
\hline \multicolumn{18}{|l|}{ metas } \\
\hline $\begin{array}{l}\text { comprometimento } \\
\text { entre as áreas } \\
\text { funcionais }\end{array}$ & & & & & & & & & $x$ & $X$ & & & & & $x$ & & 3 \\
\hline confiabilidade & & & & & & & & & $x$ & $x$ & & & & & $x$ & & 3 \\
\hline $\begin{array}{l}\text { equipes dedicadas no } \\
\text { atendimento }\end{array}$ & & & & & & & & & $x$ & & & & & & & & 1 \\
\hline flexibilidade & & & & & & & & & $x$ & & & & & & $x$ & & 2 \\
\hline $\begin{array}{l}\text { padronização de } \\
\text { documentos e } \\
\text { processos }\end{array}$ & & & & & & & & & $x$ & & & & & & & & 1 \\
\hline $\begin{array}{l}\text { planejamento de } \\
\text { soluções em conjunto }\end{array}$ & & & & & & & & & $x$ & & & & & & $\mathrm{x}$ & & 2 \\
\hline $\begin{array}{l}\text { proatividade na } \\
\text { solução de problemas }\end{array}$ & & & & & & & & & $x$ & & & & & & & & 1 \\
\hline \multicolumn{18}{|l|}{$\begin{array}{l}\text { III. ATRIBUTOS } \\
\text { REGULATÓRIOS }\end{array}$} \\
\hline $\begin{array}{l}\text { estacionamento em } \\
\text { fila dupla }\end{array}$ & & & $x$ & & & & & & & & & & & & & & 1 \\
\hline $\begin{array}{l}\text { legislação-emissão } \\
\text { de gases de } \\
\text { poluentes e efeito } \\
\text { estufa }\end{array}$ & & & $x$ & & & & & & & & & & & & & & 1 \\
\hline $\begin{array}{l}\text { obstrução do tráfego } \\
\text { por veículo de carga }\end{array}$ & $x$ & & $x$ & & & & & & & & & & & & & & 2 \\
\hline $\begin{array}{l}\text { obstrução do tráfego } \\
\text { por veículo de } \\
\text { passeio }\end{array}$ & & & $x$ & & & & & & & & & & & & & & 1 \\
\hline $\begin{array}{l}\text { regulamentação de } \\
\text { vaga para } \\
\text { carga/descarga nas } \\
\text { vias }\end{array}$ & $X$ & & & & & & & & & & & $x$ & & $x$ & & & 3 \\
\hline $\begin{array}{l}\text { restrição de } \\
\text { circulação por final da } \\
\text { placa }\end{array}$ & & & & & & $x$ & & & & & & & & & & & 1 \\
\hline $\begin{array}{l}\text { restrição de } \\
\text { circulação por horário }\end{array}$ & & & $x$ & & & $X$ & & & & & & $X$ & & $x$ & & & 4 \\
\hline $\begin{array}{l}\text { restrição de } \\
\text { circulação por } \\
\text { tamanho do veículo }\end{array}$ & & & $x$ & & & $x$ & & & & & & $x$ & & $x$ & & & 4 \\
\hline $\begin{array}{l}\text { restrição de horário } \\
\text { para carga e } \\
\text { descarga nas vias }\end{array}$ & & & $x$ & & & & & & & & & & & & & & 1 \\
\hline
\end{tabular}




\begin{tabular}{|c|c|c|c|c|c|c|c|c|c|c|c|c|c|c|c|c|c|}
\hline & $\begin{array}{l}\text { তি } \\
\text { o } \\
\stackrel{5}{=} \\
\frac{c}{0} \\
\frac{0}{5} \\
0 \\
0\end{array}$ & 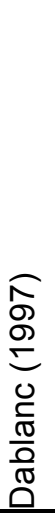 & 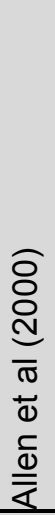 & 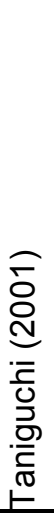 & 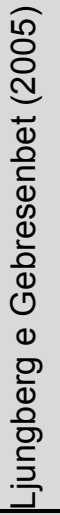 & 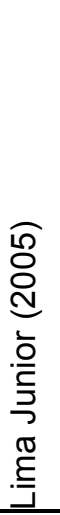 & 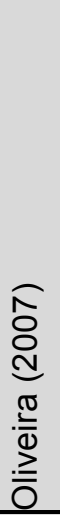 & 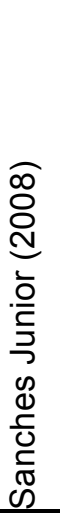 & 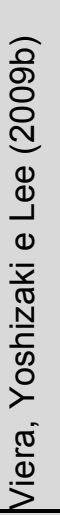 & 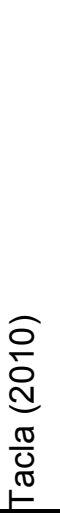 & 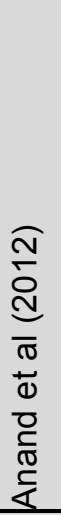 & 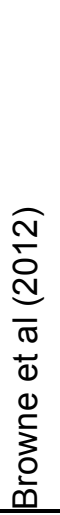 & 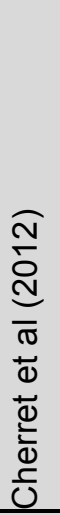 & 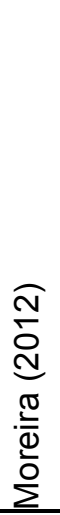 & 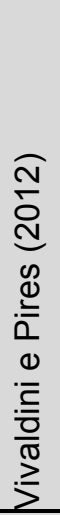 & 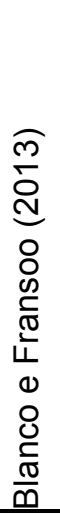 & 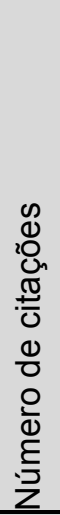 \\
\hline $\begin{array}{l}\text { veículo de passeio } \\
\text { estacionado em vaga } \\
\text { para carga e } \\
\text { descarga }\end{array}$ & $x$ & & $x$ & & & & & & & & & & & & & & 2 \\
\hline $\begin{array}{l}\text { zonas de baixa } \\
\text { emissão }\end{array}$ & & & & & & & & & & & & $x$ & & & & & 1 \\
\hline $\begin{array}{l}\text { IV. ATRIBUTOS } \\
\text { AMBIENTAIS }\end{array}$ & & & & & & & & & & & & & & & & & \\
\hline emissão de CO2 & & & & & & & & & & & $x$ & & & & & & 1 \\
\hline emissão de poluentes & & & & $x$ & & & & $x$ & & & & $x$ & & & & & 3 \\
\hline ruído & & & & & & & & & & & & $x$ & & & & & 1 \\
\hline tipo de combustível & & & $x$ & & & & & $x$ & & & & $x$ & & & & & 3 \\
\hline $\begin{array}{l}\text { coleta de recicláveis } \\
\text { ou devolução }\end{array}$ & & & & & & & & & & & & & $x$ & & & & 1 \\
\hline $\begin{array}{l}\text { V. ATRIBUTOS DE } \\
\text { RISCO }\end{array}$ & & & & & & & & & & & & & & & & & \\
\hline avaria & & & & & & & & & & & & & & $x$ & & & 1 \\
\hline congestionamento & $x$ & & $x$ & & & $x$ & & & & $x$ & & & & & & & 4 \\
\hline crédito & & & & & & & & & & & & & & & & $x$ & 1 \\
\hline local do acidente & & & & & & & & $x$ & & & & & & & & & 1 \\
\hline $\begin{array}{l}\text { número de acidentes } \\
\text { com o veículo }\end{array}$ & & & & & & & & $x$ & & & & & & & & & 1 \\
\hline $\begin{array}{l}\text { roubo ou extravio de } \\
\text { carga }\end{array}$ & & $x$ & & & & & & & & & & & & $\mathrm{x}$ & & & 2 \\
\hline $\begin{array}{l}\text { segurança contra } \\
\text { incêndio }\end{array}$ & & & & & & & & & & & & & & $\mathrm{x}$ & & & 1 \\
\hline $\begin{array}{l}\text { tipo de acidente com } \\
\text { o veículo }\end{array}$ & & & & & & & & $x$ & & & & & & & & & 1 \\
\hline $\begin{array}{l}\text { Total de citações por } \\
\text { autor }\end{array}$ & $\Lambda$ & 0 & $\stackrel{\sim}{N}$ & $\sim$ & $\stackrel{\sim}{\sim}$ & 음 & $m$ & $\stackrel{9}{\circ}$ & $\stackrel{m}{\sim}$ & 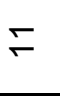 & $\curvearrowright$ & 으 & 6 & 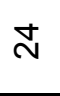 & $\wedge$ & $m$ & \\
\hline
\end{tabular}

Conforme Quadro 3, os autores das pesquisas estudadas que apresentam um maior número de atributos considerados neste trabalho são: Allen et al (2000), Moreira (2012), Sanches Junior (2008), Viera, Yoshizaki e Lee (2009b), Ljungberg e Gebresenbet (2005), Tacla (2010), Browne et al (2012) e Lima Junior (2005). 
Do total de 82 atributos citados nas pesquisas estudadas, identificam-se: 45 atributos logísticos, 13 atributos de colaboração, 11 atributos regulatórios, 5 atributos ambientais e 8 atributos de risco. Logo, pode-se observar que os atributos logísticos e de colaboração, representam mais de $70 \%$ dos atributos citados na revisão de literatura.

Ainda segundo o Quadro 3, podem-se destacar os atributos mais citados pelos autores estudados neste trabalho, e serão apresentados a seguir:

- Atributos logísticos

Relacionados à entrega: janela de entrega, frequência de entrega, tempo e local adequado para carga e descarga, quantidade entregue e filas.

Relacionados ao transporte: número de viagens, ocupação do veículo, número e tipo de veículo, custo do transporte e tempo de viagem.

- Atributos de colaboração: compartilhamento de ganhos, custos e informações, comprometimento entre as áreas funcionais, confiabilidade, flexibilidade, acordos logísticos e planejamento de soluções conjuntas.

- Atributos regulatórios: restrição de circulação por horário e tamanho de veículo e regulamentação de vaga para carga e descarga.

- Atributos ambientais: emissão de poluentes e tipo de combustível.

- Atributos de risco: congestionamento e roubo ou extravio de carga.

Como estariam relacionados os atributos acima citados à luz do referencial teórico adotado nesta pesquisa, especificamente quanto ao contexto da distribuição urbana de carga e o impacto que podem vir a causar no desempenho logístico dos Embarcadores, Operadores logísticos, Transportadores e Clientes?

Segundo Taniguchi e Tompson (2002), os agentes envolvidos na distribuição urbana de carga (Transportador, Embarcador e Operador Logístico) enfrentam, constantemente, complexos desafios impostos pelos Clientes, tais como melhoria nos fluxos de produto e de informação e entregas cada vez mais fracionadas e com maior frequência. Somam-se a isso, a diminuição das quantidades entregues e, consequentemente, a cobrança por regularidade e confiabilidade na entrega (LIMA JUNIOR, 2005). Neste sentido, o atendimento das janelas de entregas definidas pelo clientes, ausência de filas e local adequado para carga e descarga são 
determinantes para o desempenho da entrega. Logo, a agilidade na entrega é determinante para $\mathrm{o}$ atendimento do plano de entrega estabelecido com produtividade e eficiência em custos.

Muito embora sejam empregados grandes esforços por parte dos embarcadores, operadores logísticos e transportadores na otimização do sistema de distribuição de cargas, visando uma melhor eficiência e atendimento das exigências dos clientes, estes atributos relacionados à entrega acabam impactando negativamente o trânsito das cidades, por conta de um aumento no número de viagens e de veículos utilizados na movimentação de carga (TANIGUCHI;TOMPSON, 2002). Os congestionamentos das vias acabam por comprometer o tempo de viagem, podendo diminuir o número de estabelecimentos atendidos por viagem e, por conta disso, diminuindo a taxa de ocupação do veículo.

Além do impacto negativo no trânsito da cidade, o aumento de circulação de veículos também é uma das principais fontes de problemas ambientais que os centros urbanos enfrentam atualmente, tais como ruído, consumo de combustível, poluição e acidentes de trânsito (TANIGUCHI;TOMPSON, 2002). Por conta disso, as autoridades locais acabam por adotar leis ambientais de controle de emissão de gases poluentes e regulamentações sobre o tipo de combustível, que podem impactar negativamente o custo total do transporte de carga para os agentes do setor privado.

Uma distribuição de cargas eficiente está relacionada com a redução dos custos logísticos e a melhoria do desempenho logístico, pode ser um fator relevante para aumento de competitividade no GCS e dependem da colaboração dos parceiros (VIEIRA; YOSHIZAKI; LEE, 2009ª). Nesse sentido, integrar os processos chaves dos embarcadores com seus fornecedores externos (operador logístico e transportador) e clientes, buscando melhoria no gerenciamento dos fluxos logísticos numa cadeia de suprimentos, pode trazer benefícios às empresas envolvidas, principalmente em termos de desempenho e competitividade no geral (PIRES, 2011).

Logo, o compartilhamento de ganhos e custos resultantes do planejamento de soluções conjuntas podem vir a contribuir para um maior comprometimento entre as áreas funcionais dos agentes do setor privado no estabelecimento e cumprimento 
dos acordos logísticos, além de uma maior flexibilidade frente a complexidade do contexto da distribuição urbana como, por exemplo, flexibilizando o horário de entrega como alternativa para abastecimento frente às restrições de circulação por horário e tipo de veículo, em zonas de risco de roubo de carga, nos períodos sujeitos a enchentes e na ocorrência de greve no setor de transporte de carga e demais serviços essências ao funcionamento da cidade.

\subsection{INDICADORES DE DESEMPENHO LOGÍSTICO}

Esta sessão tem por objetivo descrever os indicadores de desempenho, com foco principal na distribuição física entre os principais elementos da cadeia de suprimentos: Embarcador, Operador Logístico, Transportador e Cliente.

Primeiramente, serão apresentadas as definições publicadas pelo Council of Supply Chain Management Professional (CSCMP):

"Logística é a parte dos processos da cadeia de suprimentos que planeja, implementa e controla o efetivo fluxo e estocagem de materiais, produtos, serviços e informações relacionadas desde o ponto de origem até o ponto de consumo, com o objetivo de atender às necessidades e exigências dos clientes" (CSMP, 1998, www.cscmp.org).

Esta definição sugere que a logística pode ser considerada um sistema, uma vez que suas atividades se repetem ao longo do fluxo logístico para a disponibilização dos bens e serviços ao consumidor, como ilustrado pela Figura 8.

Nesse sentido, a seguinte definição de logística apresentada pelo CSMP (1998) descreve o sistema logístico através de suas principais atividades:

As atividades de um sistema logístico típico são: serviço ao cliente, gerenciamento de frota, tráfego, transporte, armazenagem, estocagem, atendimento de pedidos, distribuição. Em graus variados, o sistema logístico também inclui compras, planejamento e programação da produção, manuseio de produtos devolvidos, reciclagem e atendimento ao cliente" (CSMP, 1998, www.cscmp.org). 


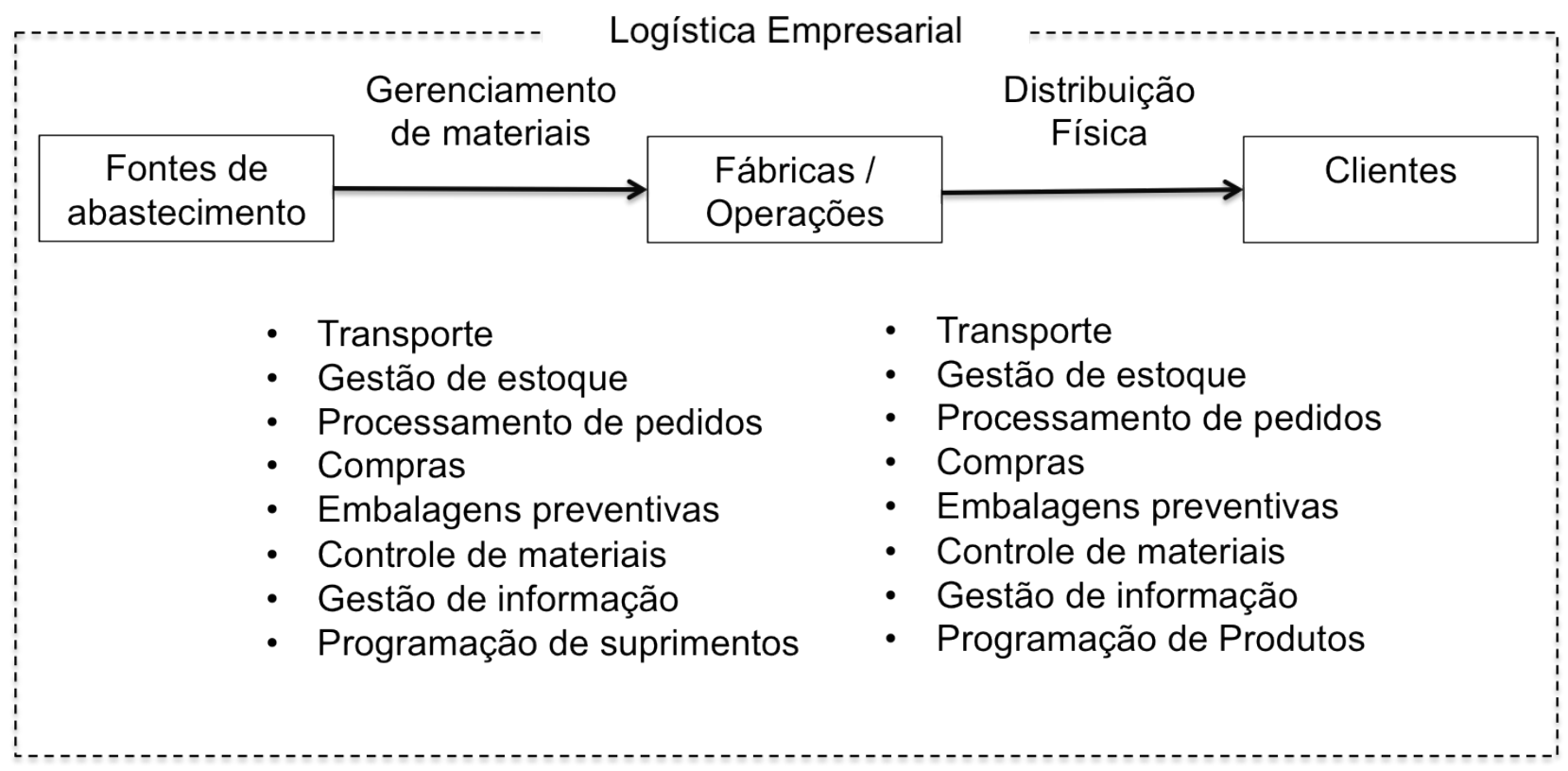

Figura 8 - Atividades logísticas na cadeia de suprimentos genérica Fonte: Ballou (2006, p. 31).

As atividades logísticas de uma cadeia de suprimentos genérica (Figura 8) podem ser classificas em "atividades-chave": serviços ao cliente, transporte, gestão de estoque, fluxo de informação e processamento de pedido, e em "atividades de suporte": armazenagem, manuseio dos materiais, compras, embalagem protetora contra perdas e danos, programação de produção, programação de suprimentos e manutenção de informação.

As atividades-chave, que são cada vez mais desempenhadas por um operador logístico, um dos elementos de uma cadeia de suprimentos típica do varejo (Figura 9), são essenciais para a eficácia do fluxo de materiais e produtos, além de responderem pela maior parcela dos custos logísticos, que pode representar de 50 a $70 \%$ dos custos logísticos totais (BALLOU, 2006). 


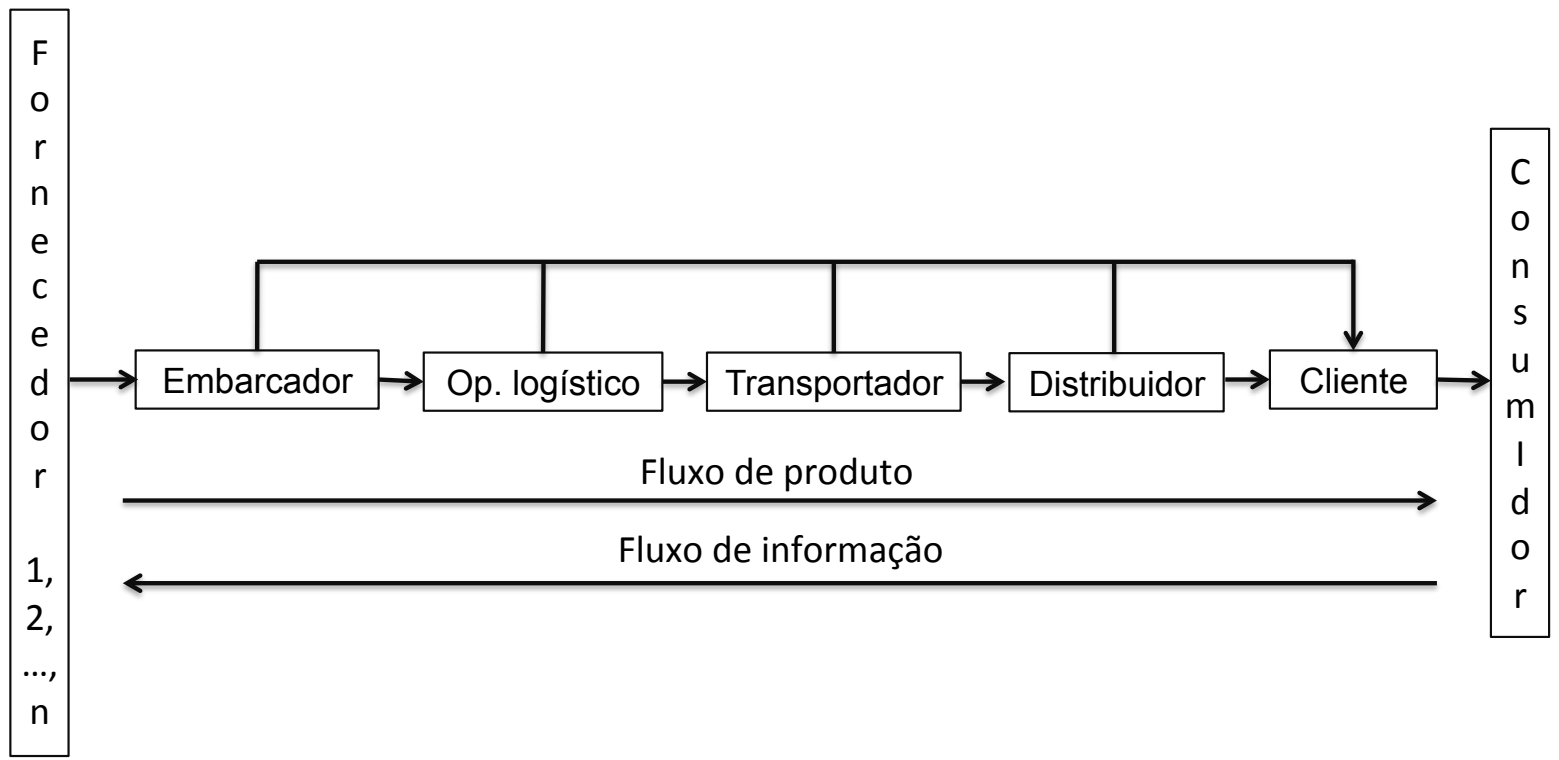

Figura 9 - Elementos de uma cadeia de suprimentos típica do varejo Fonte: Adaptado de Vieira (2006, p.28)

Logo, podem-se destacar a participação dos principais agentes de investigação desta dissertação (Embarcador, Operador logístico, Transportador e Cliente) em uma cadeia de suprimentos típica do varejo (Figura 9), sendo o operador logístico a empresa focal por se especializar na prestação de serviços logísticos na distribuição de carga.

Segundo Pavan e Pires (2004), o atendimento das necessidades e expectativas do cliente final e a redução de custos ao longo da cadeia de suprimentos são os objetivos fundamentais do Gerenciamento da Cadeia de Suprimentos (GCS). Logo, a integração das atividades-chaves e o gerenciamento dos fluxos logísticos, podem contribuir positivamente para um melhor desempenho e competitividade das empresas envolvidas e, consequentemente, da cadeia de suprimentos (PIRES, 2011).

Primeiramente, deve ser feita uma seleção de aspectos que devem ser analisados e controlados, considerando o contexto e particularidades do setor que a cadeia de suprimentos está inserida, contribuindo, desta forma, para a adoção de indicadores de desempenho adequados aos objetivos e características das empresas e/ou da cadeia de suprimentos (PAVAN; PIRES 2004). Uma forma de identificar os indicadores individuais em cada uma das empresas e os indicadores comuns, ou seja, que podem vir a medir o desempenho da cadeia de suprimentos está apresentado na Figura 10. 


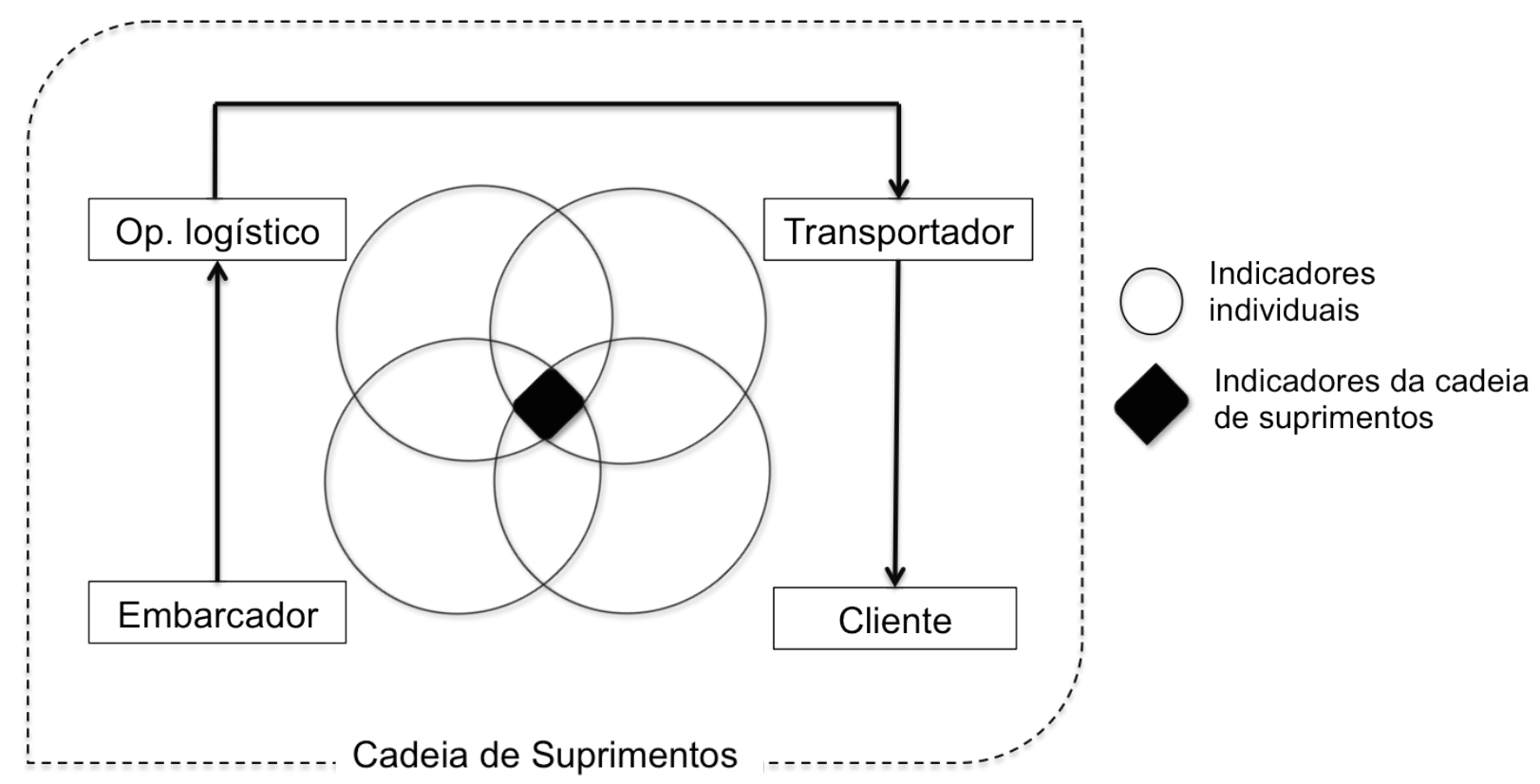

Figura 10 - Indicadores Individuais e da Cadeia de Suprimentos

Fonte: Baseada em Pires e Aravechia (2001)

A Figura 10 mostra a intersecção dos indicadores individuais dos agentes participantes de uma cadeia de suprimentos simplificada e, desta forma, poderia indicar quais seriam os indicadores de desempenho dessa cadeia.

Nessa linha, Pires (2011) destaca os indicadores fundamentais para o desempenho da cadeia de suprimentos, ou seja, que estão relacionados ao resultado global da cadeia e são determinantes para a sua competitividade no mercado, como, por exemplo: custos de produção, de estoque e de distribuição, volume de vendas, lucro líquido, prazo de entrega, tempo do ciclo do pedido, além dos indicadores relacionados a qualidade e agilidade no atendimento ao cliente final, tais como: entregas no prazo, tempo de resposta, reclamações dos clientes e confiabilidade de entrega.

Allen et al. (2000) sugerem em seu estudo os indicadores de desempenho relevantes na avaliação dos efeitos das políticas de carga urbana adotadas nas cidades de Birgmingham, Basingstoke e Norwick, classificados em operacionais, financeiros e ambientais, e são apresentados a seguir:

- Indicadores operacionais: número de coletas e/ou entregas por viagens, tempo total gasto na viagem por veículo, tempo de deslocamento por coleta e/ou entrega, ocupação do veículo na saída do depósito, relação entre o tempo que o veículo ficou parado para realizar as atividades de coletas e/ou entregas e o 
tempo total de viagem, velocidade média por viagem com e sem paradas, distância total percorrida, quantidade de entregas realizadas com veículo estacionado em via pública e em local apropriado para carga e descarga no cliente.

- Indicador financeiro: custo operacional total por viagem para o operador logístico.

- Indicadores ambientais: quantidade total de poluentes emitidos estratificados em $\mathrm{CO}, \mathrm{CO} 2$ e NO2 por viagem.

Nesta dissertação serão considerados os indicadores de desempenho logístico que podem ser impactados pelos atributos de distribuição de carga na RMSP, como os seguintes indicadores de nível de serviços logístico: percentual de entregas no prazo e percentual de pedido no prazo e completo - On Time In Full (OTIF).

\subsection{REGIÃO METROPOLITANA DE SÃO PAULO}

Neste tópico, serão apresentadas as principais características da Região Metropolitana de São Paulo (RMSP) no que se refere à sua complexidade e relevância no contexto urbano das maiores aglomerações urbano no mundo, assim como as principais políticas públicas do município de São Paulo para transporte urbano de carga que podem impactar a distribuição urbana de cargas na RMSP.

\subsubsection{Caracterização}

A RMSP é a maior concentração urbana do Brasil, composta por 39 municípios e está localizada na região Sudeste do Brasil. A RMSP é conhecida por sua influência nacional e internacional, e por sua expressividade política, econômica e cultural (Fundação Seade, 2011). 
Em termos econômicos, sua grandeza é constatada pela expressividade de seu Produto Interno Bruto (PIB), que segundo dados da Fundação Seade em parceria com o IBGE, em 2010, foi estimado em R 760 bilhões, o que confere a RMSP a segunda posição no ranking nacional, ficando atrás apenas do Estado de São Paulo com PIB de R\$1.349,5 bilhões, respondendo por $56 \%$ do PIB do Brasil (IBGE, 2010).

A sua expressividade populacional pode ser notada quando analisamos a Figura 11, que demonstra a evolução populacional da Região Metropolitana de São Paulo, no período de 1980 a 2010, quando comparada com o Estado de São Paulo, o Brasil e a cidade de São Paulo, polo regional mais populoso da América do Sul que, por se tratar de uma cidade com mais de 10 milhões de habitantes, pode ser classificada como uma megacidade (ONU, 2006).

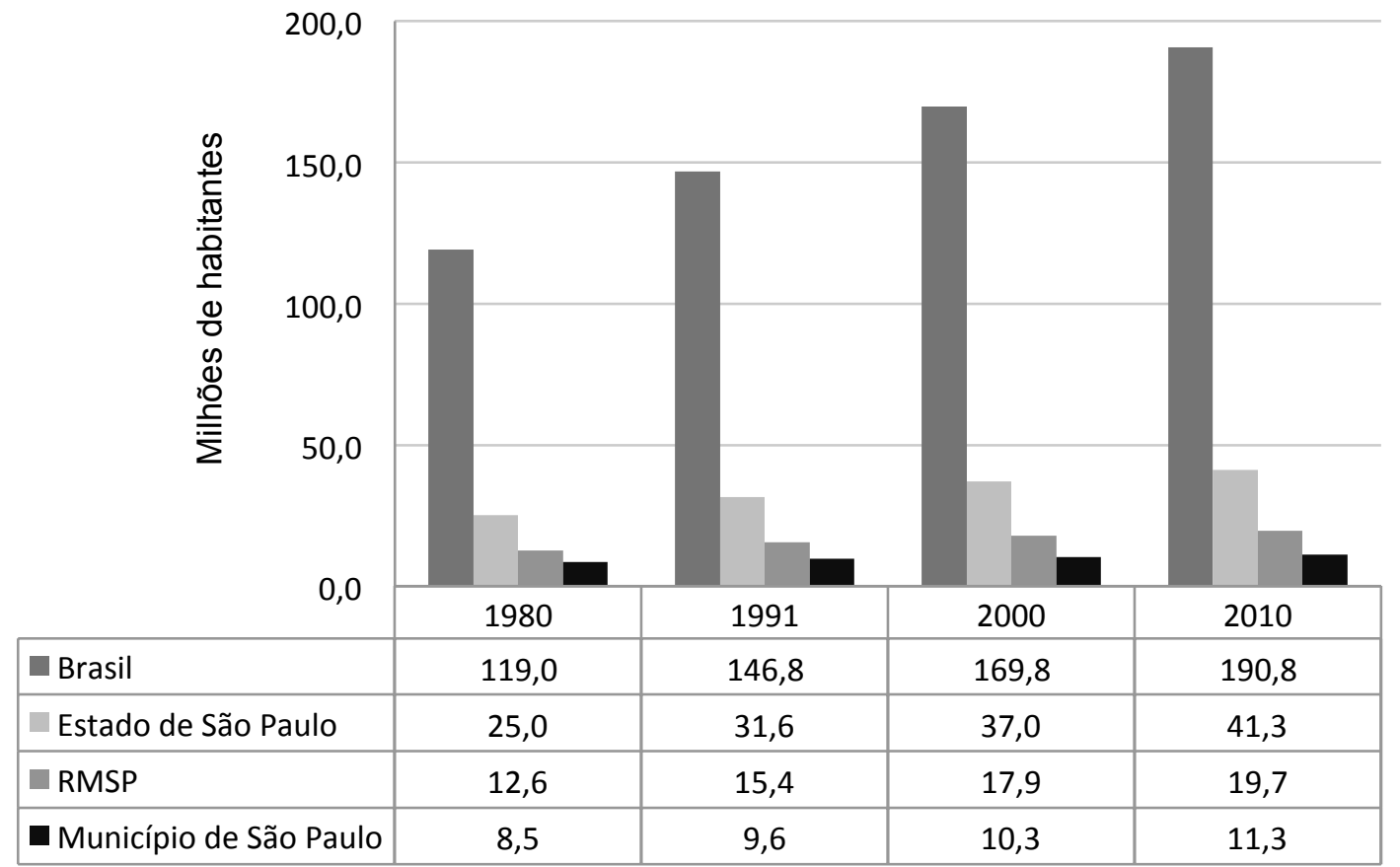

Figura 11 - Evolução da população - Brasil, Estado de São Paulo, RMSP e Município de São Paulo $(1980-2010)$

Fonte: IBGE (2010) - Censos Demográficos. Secretaria Municipal de Desenvolvimento Urbano (SMDU) - Departamento de Estatística e Produção de informação (DIPRO).

Além disso, a população da RMSP se destaca também por ser essencialmente urbana. A taxa de urbanização na RMSP em 2010 ultrapassou 98\%, o que representa 19,4 milhões de pessoas, sendo maior do que a taxa de urbanização no estado de São Paulo, conforme mostra a Figura 12, baseado nos dados do IBGE (2010) e publicado pela Fundação Seade (2010). 


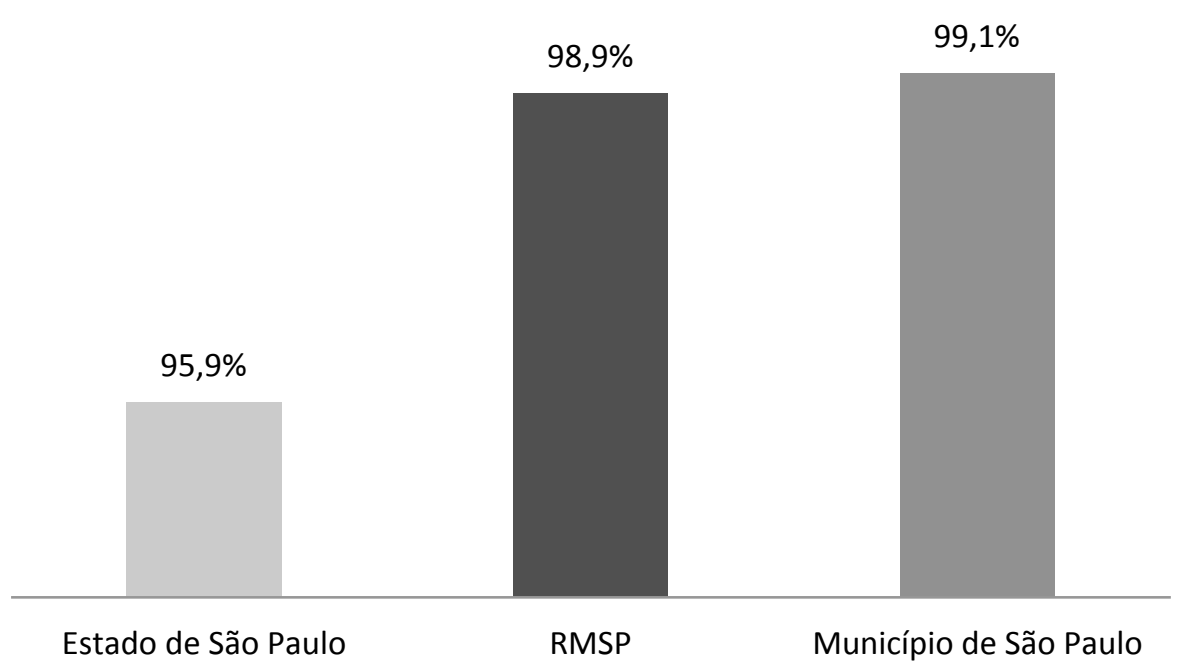

Figura 12 - Taxas de urbanização em 2010 - Estado de São Paulo, RMSP e Município de São Paulo Fonte: IBGE (2010) - Censos Demográficos e Fundação Seade (2010)

Ainda sobre os aspectos referentes à urbanização da RMSP, a Figura 13 apresenta a evolução de sua população total, urbana e rural nas últimas décadas.

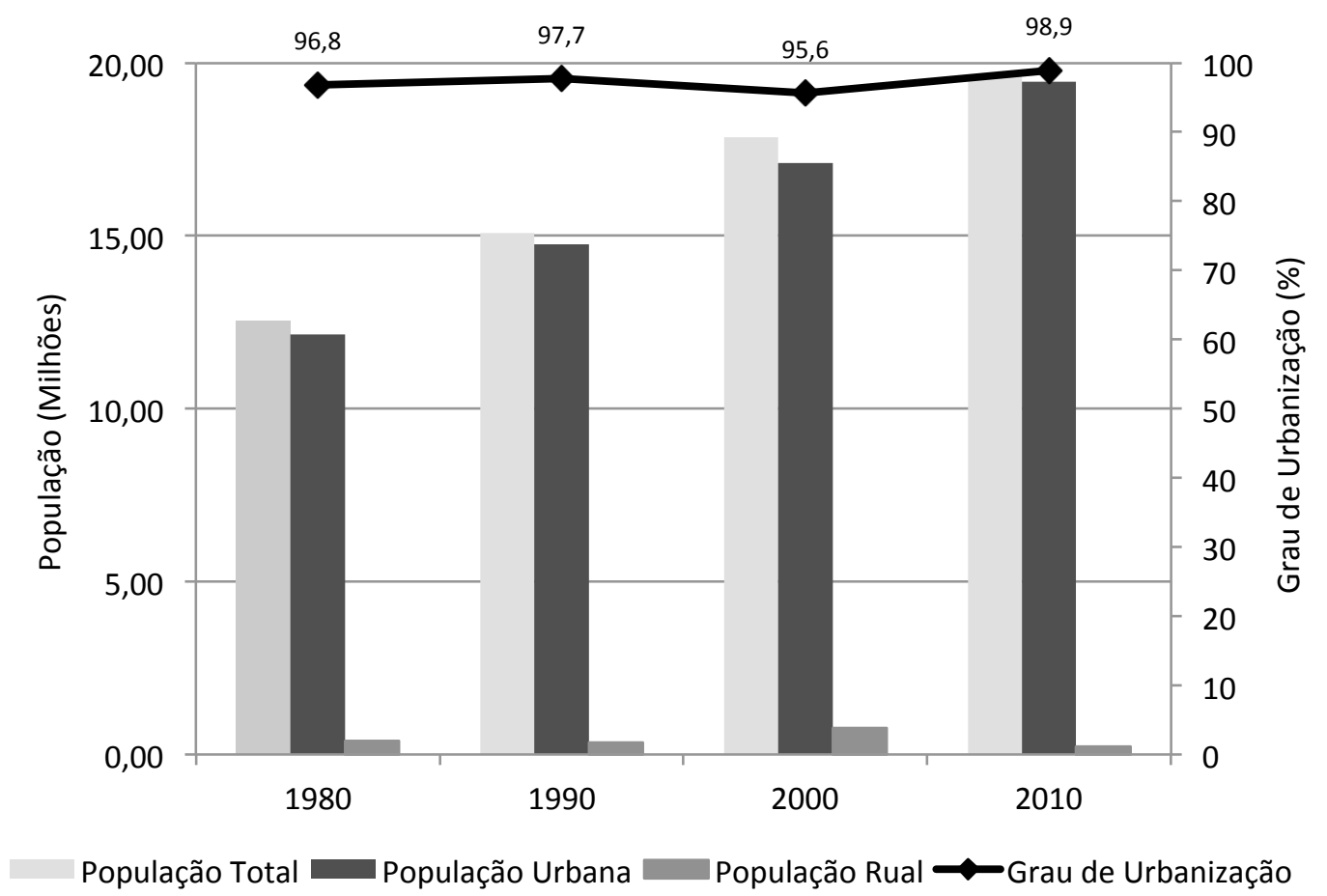

Figura 13 - População urbana e rural - Grau de urbanização- Município de São Paulo - 1990 a 2010 Fonte IBGE (2010) - Censos Demográficos. Prefeitura do Município de São Paulo

A Figura 13 demonstra que o aumento da população urbana do município na última década respondeu pelo crescimento da população total nesse período, fazendo com 
que o grau de urbanização do município voltasse a superar o patamar de $97 \%$ alcançado anteriormente na década de 90.

Outro aspecto comum aos grandes aglomerados urbanos e megacidades é o elevado índice de congestionamento, não mais restrito aos horários de pico, que a população da RMSP enfrenta diariamente em suas principais vias, o qual vem sendo agravado pelo aumento crescente da frota de veículos registrados na RMSP (Tabela 1).

Tabela 1 - Evolução da frota no município de São Paulo por tipo de veículo

\begin{tabular}{lrrrrr}
\hline Ano & \multicolumn{1}{c}{2008} & \multicolumn{1}{c}{2009} & \multicolumn{1}{c}{2010} & \multicolumn{1}{c}{2011} & \multicolumn{1}{c}{2012} \\
\hline Frota Total & 8.646 .596 & 9.219 .209 & 9.787 .713 & 10.354 .472 & 10.847 .328 \\
Tipo 1 & 1.114 .125 & 1.218 .677 & 1.334 .878 & 1.449 .356 & 1.531 .729 \\
Tipo 2 & 872.812 & 951.475 & 1.046 .396 & 1.156 .961 & 1.248 .534 \\
Tipo 3 & 6.230 .135 & 6.604 .879 & 6.940 .585 & 7.258 .129 & 7.563 .986 \\
Tipo 4 & 58.782 & 59.403 & 61.727 & 64.901 & 66.562 \\
Tipo 5 & 223.594 & 229.540 & 236.350 & 243.822 & 245.526 \\
Tipo 6 & 109.846 & 115.143 & 122.420 & 130.444 & 137.176 \\
Tipo 7 & 37.302 & 40.092 & 45.357 & 50.859 & 53.815 \\
\hline \multicolumn{5}{c}{ Fonte: DETRAN-SP (2013). }
\end{tabular}

A Tabela 1 apresenta os dados referentes à frota total e por tipo de veículo registrado no DETRAN-SP no período de 2008 a 2012. O DETRAN-SP classifica a frota por tipo de veículo, conforme a seguir:

Tipo 1 - Motocicleta, motoneta, motociclo, triciclo e quadriculo.

Tipo 2 - Micro ônibus, camioneta, caminhonete e utilitário.

Tipo 3 - Automóvel.

Tipo 4 - Ônibus.

Tipo 5 - Caminhão.

Tipo 6 - Reboque e semi-reboque.

Tipo 7 - Outros.

Baseado nos dados da Tabela 1, percebe-se um aumento expressivo, superior a $43 \%$, no número de veículos registrados no DETRAN-SP na categoria 2 no período de 2008 a 2012. Esse crescimento pode ser reflexo da adoção de uma política de restrição de circulação na cidade de São Paulo para caminhões de grande porte desde 2007 e, consequentemente, da necessidade de utilização de veículos de carga menores com capacidade máxima de 4 toneladas e isentos de restrição de 
circulação, os Veículos Urbanos de Carga (VUCs), assim como caminhonetes e utilitários. Essa medida de restrição de tráfego será melhor detalhada no próximo tópico desta dissertação.

Além do aumento da frota de veículos de carga de menor porte, nota-se um aumento de mais de $21 \%$ no número de veículos particulares desde 2008 . Segundo levantamento feito pelo DETRAN-SP em parceria com a Fundação Seade, o número de habitantes por total de veículos na região diminuiu de 3,04 em 2002 para 1,84 em 2012, semelhante ao índice apresentado pelo Estado de São Paulo no mesmo ano.

No caso da cidade de São Paulo, o índice é ainda menor, 1,67 habitante por veículo registrado na cidade em 2012. O trânsito na cidade chegou a tal ponto que a velocidade média anual dos veículos nos horários de picos é inferior a $20 \mathrm{~km} / \mathrm{h}$, ou seja, menor do que a alcançada por uma pessoa andando de bicicleta (CET, 2013).

\subsubsection{Políticas para transporte urbano}

Este tópico tem a finalidade de apresentar as principais políticas públicas para transporte urbano adotadas na cidade de São Paulo que podem impactar a estratégia de distribuição de carga das empresas envolvidas (Embarcador, Operador logístico, Transportador e Cliente).

Ao mesmo tempo que o transporte urbano de cargas é um serviço essencial para o funcionamento da cidade, ele contribui para agravar ainda mais a situação do trânsito na cidade de São Paulo e, consequentemente, na RMSP, à medida que disputa com os veículos de transporte urbano de pessoas, carros de passeio e prestadores de serviços, as mesmas vias de um sistema viário que está comprometido pelo excesso de veículos.

Nas últimas décadas, o governo da cidade de São Paulo, através da Companhia de Engenharia de Tráfego (CET-SP), vem adotando medidas que restringem a circulação de caminhões na cidade e estimulam o abastecimento noturno. Em contrapartida, existe a possibilidade de abastecimento com caminhões menores, os VUCs, durante o dia e em determinadas vias. 
Em 1997, foi implementada a Operação Horário de Pico, popularmente conhecida como "rodízio" de carros, com o objetivo de minimizar a emissão de poluentes. Em 2008, a prefeitura da cidade de São Paulo decidiu também restringir a circulação de caminhões, como forma de minimizar o trânsito na cidade.

O rodízio de veículos restringe a circulação de carros e caminhões de acordo com a conciliação entre o final da placa e o dia da semana (Quadro 4).

Quadro 4 - Rodízio de carros e caminhões

\begin{tabular}{cccccc}
\hline Dia da semana & Segunda & Terça & Quarta & Quinta & Sexta \\
\hline Final da placa & 0 e 1 & 2 e 3 & 4 e 5 & 6 e 7 & 8 e 9 \\
\hline
\end{tabular}

Fonte: CET-SP (2013)

Por exemplo, veículos com final de placa 1 estão proibidos de circular às segundasfeiras nos períodos de $7 \mathrm{~h} 00$ às $10 \mathrm{~h} 00$ e $17 \mathrm{~h} 00$ às $20 \mathrm{~h} 00$, exceto feriados, no centro expandido da cidade que é delimitado pelo mini anel viário (Figura 14). No entanto, a restrição não se aplica para o transporte de produtos alimentícios perecíveis e serviços públicos essências como, por exemplo, coleta de lixo, bombeiros e correios.

Além do rodízio, o governo de São Paulo vem adotando, desde 1982, uma série de medidas como forma de atenuar os transtornos causados pelo tráfego de caminhões na cidade. A seguir, serão descritas as atuais políticas públicas que regularizam a circulação de veículos de cargas em determinados perímetros e vias da cidade, e estão sintetizadas na Figura 14.

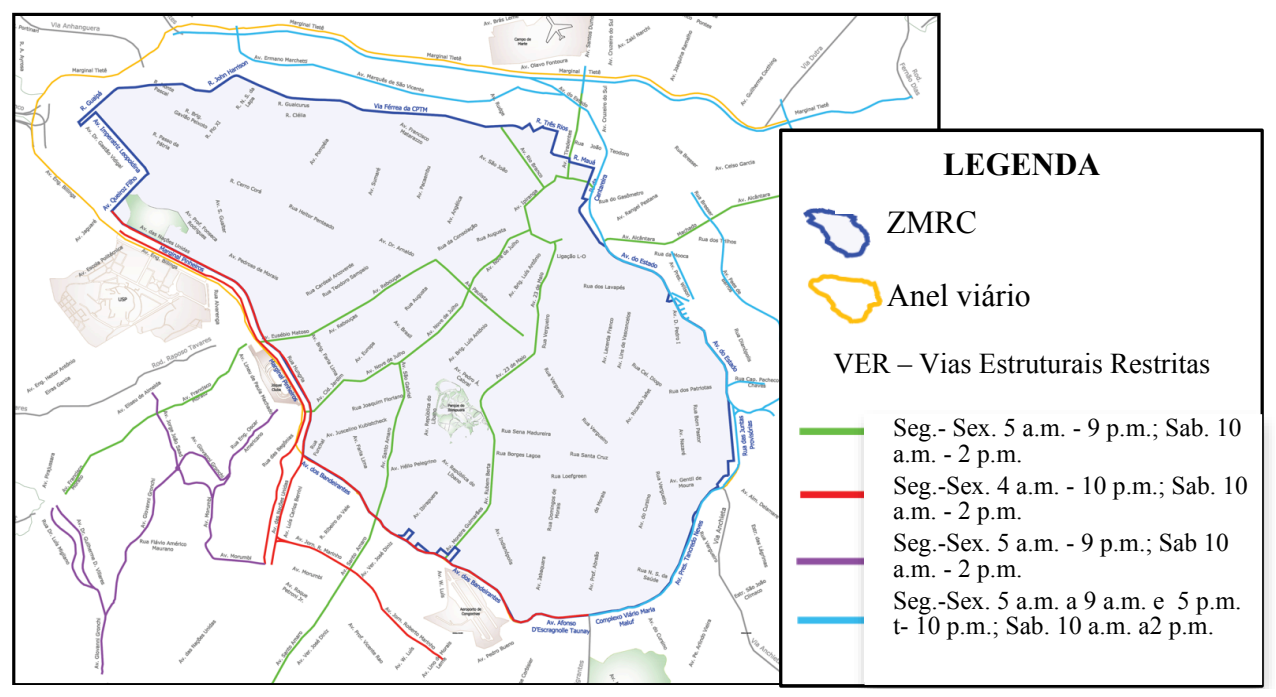

Figura 14 - Mapa das restrições de circulação de veículos de carga Fonte CET-SP 2013 
- ZMRC - Zona de Máxima Restrição de Circulação: Foi estabelecida para que a movimentação da carga urbana ocorra, preferencialmente, de madrugada e à noite. Proibido o Trânsito de Caminhões de $2^{\mathrm{a}}$ a $6^{\mathrm{a}}$ feira das $5 \mathrm{~h}$ às $21 \mathrm{~h}$ e aos sábados das $10 \mathrm{~h}$ às $14 \mathrm{~h}$, exceto feriados. Veículos com autorização especial transportando produtos alimentícios perecíveis são autorizados a circular entre 5 e $12 \mathrm{~h}$. Os VUCs são autorizados a circular no período integral.

- VER - Vias Estruturais Restritas - São vias, túneis, viadutos e pontes de grande circulação, responsáveis pela articulação do sistema viário entre regiões da cidade e também acessadas para deslocamentos de longa distância. Possuem regulamentação local referente aos horários de circulação para veículos como os VUCs e para o transporte de alimentos perecíveis.

Os veículos, caminhões e VUCs, cujas atividades ou natureza dos produtos transportados são classificadas como exceções previstas nas regulamentações da ZMRC e das VER, devem portar o Cartão Caminhão, que é uma autorização especial para circulação e estacionamento obtida através de cadastro na Secretaria Municipal de Transporte (SMT). Por exemplo, os VUCs possuem horários e dias específicos para circulação nessas zonas e vias de restrição para atividades como: coleta de lixo, transporte de alimentos perecíveis e transporte de valores.

- ZERC - Zonas Especiais de Restrição de Circulação - áreas residenciais nas quais a circulação de caminhões é proibida, inclusive para os VUCs.

Políticas de restrição de tráfego de caminhões em centros urbanos são algumas das medidas mais utilizadas em países emergentes. No entanto, causam muitas discussões sobre a sua eficácia na redução de congestionamentos, poluição e número de acidente envolvendo veículo de carga, uma vez que as empresas prestadoras de serviços logísticos podem vir a utilizar um maior número de veículos de carga de menor porte e isentos de restrição de circulação para atender a demanda diária e o nível de serviço exigido pelo cliente (CASTRO; KUSE, 2005).

Além das políticas de restrição de circulação adotadas pelo governo de São Paulo, destaca-se também a lei Federal $n^{\circ} 12.619$ definida pela Presidência da República, em 30 de abril de 2012, que regulamenta a jornada de trabalho do motorista, assegurado um jornada de trabalho com intervalo mínimo de 1 hora para refeição, 
intervalo de repouso diário de 11 horas a cada 24 horas e descanso semanal de 35 horas. Essa medida ficou conhecida como "Lei do motorista" e existe uma preocupação quanto ao impacto que ela pode vir a gerar na distribuição urbana de carga. 


\section{METODOLOGIA DE PESQUISA}

A metodologia utilizada para empreender esta pesquisa tem caráter exploratório por meio de entrevistas com gestores de empresas envolvidas na distribuição de carga, Embarcadores, Operadores logísticos, Transportadores e Varejistas. Essas empresas constituem dois estudos de caso, em que os operadores logísticos se constituem como objetivo central, por serem os agentes intermediários entre a origem e o destino da carga e por envolverem o maior número de relacionamentos dentre os responsáveis pela distribuição de carga na cidade de São Paulo.

A pesquisa também tem caráter descritivo com abordagem quantitativa, visando atender ao segundo objetivo proposto nesta dissertação. Assim, foi feito um levantamento de dados junto aos agentes prestadores de serviços logísticos nesse estudo (Operador Logístico e Transportador), e tendo como propósito a obtenção de dados necessários para análise estatística (MIGUEL, 2007; YIN, 2001).

A seguir, será feito o detalhamento da metodologia, que consiste do delineamento e fases da pesquisa, da definição dos itens de pesquisa, de que forma foram coletados os dados e, finalmente, como esta estrutura metodológica e informações obtidas respondem ao objetivo proposto neste trabalho.

\subsection{DELINEAMENTO E FASES DA PESQUISA}

A metodologia deste trabalho consiste das seguintes fases e procedimentos técnicos de pesquisa:

Fase exploratória inicial:

- Revisão da literatura

- Elaboração do protocolo de entrevista (Apêndice A)

- Estudo de caso 
Fase quantitativa descritiva:

1. Elaboração e validação do questionário (Apêndice B)

2. Levantamento dos dados

3. Análises estatísticas descritivas

A Figura 15 sintetiza as etapas a serem executados nesta pesquisa, assim como em que momento serão adotados os procedimentos técnicos de pesquisa listados acima:

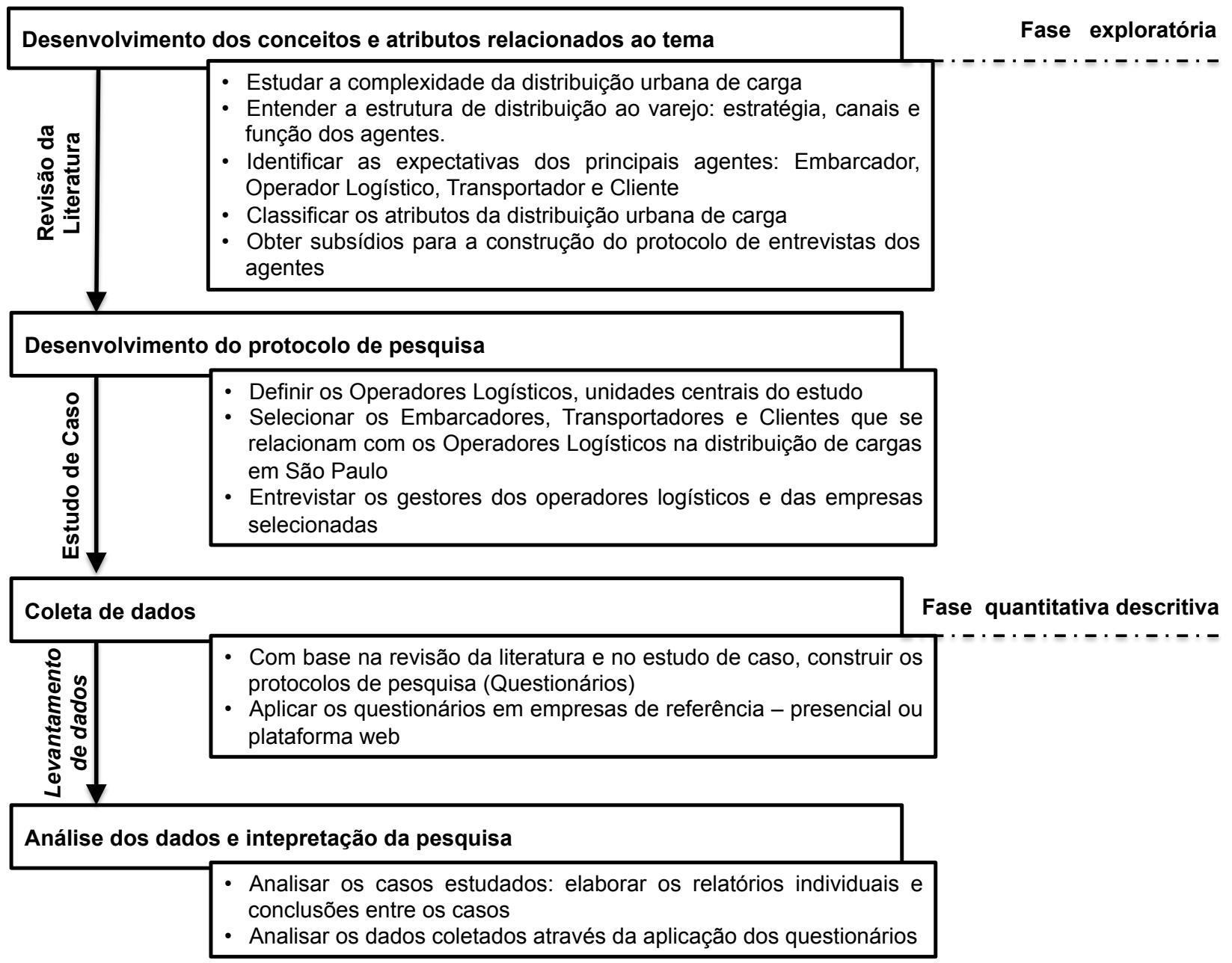

Figura 15 - Síntese das etapas e procedimentos técnicos desta pesquisa Fonte: Adaptado de Miguel, P.A.C. (2007); Yin, R. K. (2001), p. 82 


\subsection{DEFINIÇÃO DOS ITENS DE PESQUISA}

A abordagem desta pesquisa será conduzida conforme modelo proposto na Figura 16. O objetivo de conhecer e identificar os atributos da distribuição urbana de carga, aqui classificados em atributos logísticos, de colaboração, regulatórios, ambientais e de risco e, além disso, alguns indicadores de desempenho logísticos das empresas, os quais podem ser impactados pelos problemas da grande cidade.

A Figura 16 foi construída a partir da revisão da literatura, com foco no papel dos agentes e nos atributos que podem vir a influenciar o desempenho logístico das empresas Embarcador, Transportador, Operador Logístico e Cliente.

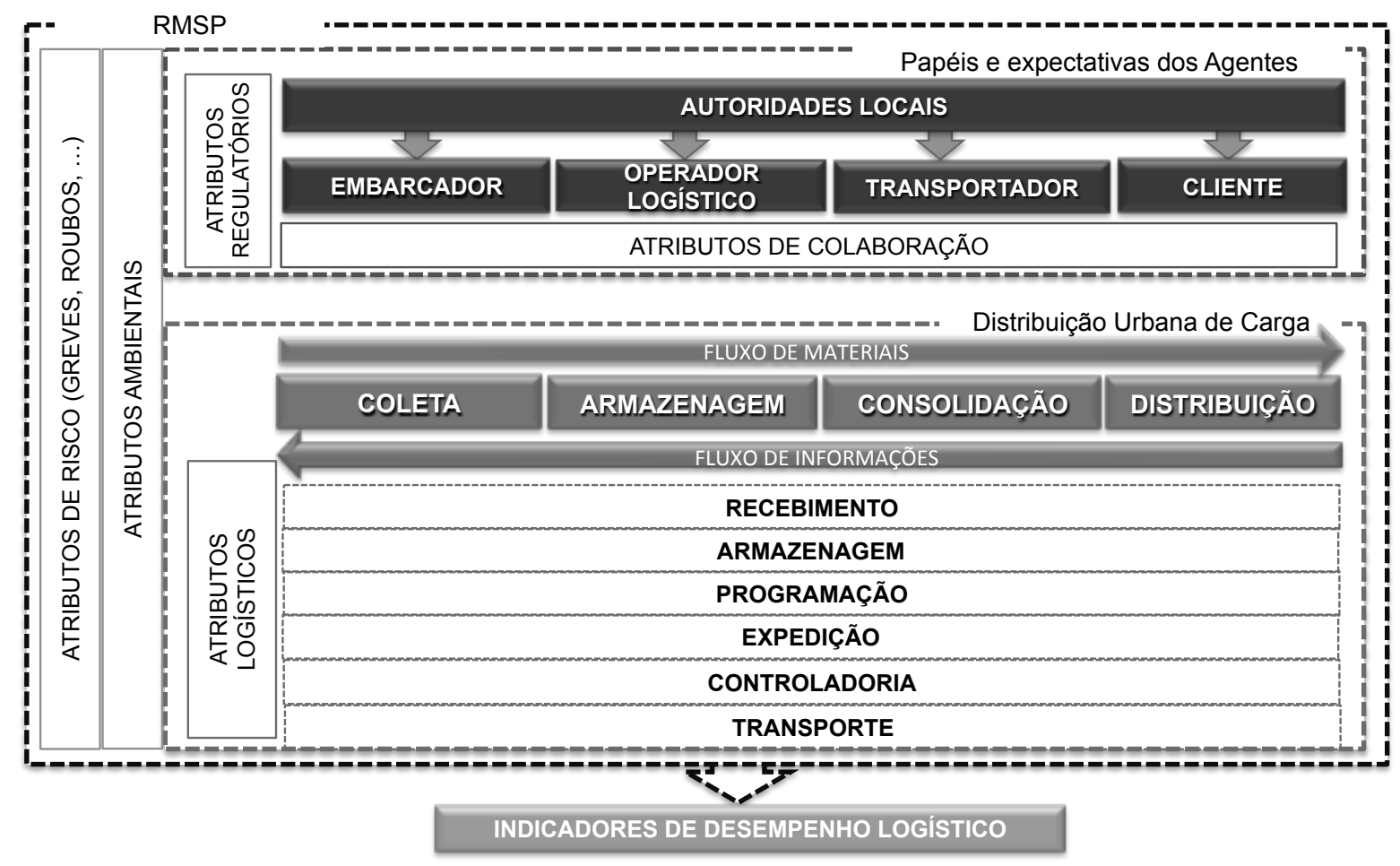

Figura 16 - Abordagem da pesquisa para definição dos atributos Fonte - Baseado em Ballou (2006) e Novaes (2004).

A Figura 16 apresenta de forma esquemática uma estrutura para a coleta de dados nos estudos de caso, detalhada a seguir:

a) Identificar os atributos regulatórios, ou seja, as políticas públicas, normas e restrições, que podem vir a influenciar ou alterar a estratégia adotada na distribuição urbana de carga pelos agentes. Consequentemente, podem vir a 
impactar o desempenho logístico das empresas envolvidas à medida que adiciona restrição às entregas de mercadorias, por exemplo zonas de circulação.

b) Identificar os atributos de colaboração, envolvidos entre dois ou mais agentes, com o intuito de melhorar a eficiência da distribuição de carga. Estes atributos podem impactar diretamente as operações de distribuição urbana de carga e o desempenho logísticos das empresas à medida que possa ocorrer, por exemplo, maior flexibilidade na entrega de mercadorias ao destinatário final.

c) Identificar os atributos logísticos relacionados às operações realizadas na distribuição de carga (coleta, armazenagem, consolidação e distribuição), associados às atividades que ocorrem durante a movimentação de carga (recebimento, armazenagem, programação, expedição, controladoria e transporte). Esses atributos têm impacto direto à medida que as empresas têm que atender a um maior volume e com maior frequência de entrega.

d) Identificar os atributos de risco (roubos, enchentes, etc.) e ambientais (práticas de logística reversa, combustíveis alternativos, etc.) que influenciam tanto o relacionamento entre os agentes na busca por soluções colaborativas quanto o desempenho logístico de cada empresa envolvida, porque roubo de carga tem adicionado custos com contratação de seguro, assistentes para carga e descarga, etc..

e) Verificar quais são os indicadores de desempenho logísticos adotados pelas empresas prestadoras de serviços logísticos, que atuam na distribuição urbana de carga na RMSP.

\subsection{PROCEDIMENTOS METODOLÓGICOS DO ESTUDO DE CASO}

Os estudos de caso, realizados no período de setembro de 2013 a janeiro de 2014, tiveram por objetivo identificar os papéis e percepções quanto aos atributos da distribuição urbana de carga na RMSP das empresas envolvidas: Embarcador, Operador logístico, Transportador e Cliente. 
Os estudos de caso foram desenvolvidos em dois Operados logísticos que atuam na distribuição de carga na RMSP por meio de entrevistas individuais, presenciais ou por telefone, com representantes do setor de logística dessas empresas. Da mesma forma foram entrevistados os representantes das Transportadoras que prestam serviços a essas empresas. Durante as entrevistas procurou-se levantar as informações contidas no Protocolo de entrevista: Pesquisa no Operador Logístico e Transportador (Apêndice A).

O protocolo de entrevista foi adaptado de Allen et al. (2000), Moreira (2012), Ljungberg e Gebresenbet (2005), Sanchez Junior (2008) e Vieira (2006), e está estruturado em sete Blocos descritos a seguir:

- Bloco 1: caracterizar a empresa pesquisada.

- Bloco 2: identificar os atributos logísticos, ou seja, relacionados às atividades que a empresa realiza na distribuição de carga na RMSP, tais como: recebimento, estocagem, programação, transporte, controladoria e expedição, e que podem vir a impactar as operações de coleta, armazenagem, consolidação e distribuição de carga na RMSP.

- Bloco 3: identificar os problemas que a empresa enfrenta na distribuição de carga na RMSP.

- Bloco 4: identificar os atributos regulatórios que podem vir a impactar as operações de coleta, armazenagem, consolidação e distribuição de carga na RMSP.

- Bloco 5: identificar os atributos de colaboração que são adotados pela empresa na interação com um ou mais agentes participantes da distribuição de carga na RMSP

- Bloco 6: identificar os atributos ambientais e verificar se a adoção destes atributos é uma iniciativa da empresa ou uma adequação aos controles e restrições definidos pelas autoridades ou demais agentes.

- Bloco 7: identificar iniciativas que possam vir a melhorar a distribuição de carga na grande São Paulo sob o ponto de vista do entrevistado.

Além dos Operadores Logísticos e Transportadores, foram realizadas entrevistas individuais, presenciais ou por telefone, com os Embarcadores e seus Clientes, pertencentes à cadeia de suprimentos dos Operadores logísticos deste estudo. As 
entrevistas com esses agentes limitaram-se ao entendimento das suas expectativas, seus papéis na distribuição de carga na RMSP e também às suas percepções quanto aos atributos de distribuição de carga no desempenho logístico de suas empresas.

Com o intuito de preservar o sigilo das empresas e dos entrevistados, as 12 empresas que participaram deste estudo foram identificadas por meio de siglas e os cargos dos entrevistados não serão informados. Durante os estudos de caso foram realizadas 38 entrevistas individuais, como mostram as Tabelas 2 e 3.

Tabela 2 - Entrevistas com representantes das empresas - Estudo de caso A

\begin{tabular}{lcc}
\hline \multicolumn{1}{c}{ Agente } & $\begin{array}{c}\text { Número de } \\
\text { entrevistados * }\end{array}$ & $\begin{array}{c}\text { Duração total das } \\
\text { entrevistas }\end{array}$ \\
\hline Embarcadores & 3 & $4 \mathrm{~h} 30$ \\
Embarcador A1 & 2 & $2 \mathrm{~h} 30$ \\
Embarcador A2 & 1 & $2 \mathrm{~h} 00$ \\
Clientes (destinatário final) & 4 & $2 \mathrm{~h} 00$ \\
Cliente A1a e Cliente A1b & 2 & $1 \mathrm{~h} 00$ \\
Cliente A2a e Cliente A2b & 2 & $1 \mathrm{~h} 00$ \\
Operador A & 4 & $10 \mathrm{~h} 00$ \\
Transportador A & 4 & $6 \mathrm{~h} 00$ \\
Total & $\mathbf{1 5}$ & $\mathbf{2 2 h} \mathbf{3 0}$ \\
\hline
\end{tabular}

Tabela 3 - Entrevistas com representantes das empresas - Estudo de caso B

\begin{tabular}{lcc}
\hline Agente & $\begin{array}{c}\text { Número de } \\
\text { entrevistados * }\end{array}$ & $\begin{array}{c}\text { Duração total das } \\
\text { entrevistas }\end{array}$ \\
\hline Embarcadores & 5 & $4 \mathrm{~h} 30 \mathrm{~min}$ \\
Embarcador B1 & 2 & $2 \mathrm{~h} 00$ \\
Embarcador B2 & 3 & $2 \mathrm{~h} 30$ \\
Clientes (destinatário final) & 4 & $2 \mathrm{~h} 00$ \\
Cliente B1a e B1b & 2 & $1 \mathrm{~h} 00$ \\
Cliente B2a e B2b & 2 & $1 \mathrm{~h} 00$ \\
Operador logístico B & 6 & $7 \mathrm{~h} 00$ \\
Transportador B & 7 & $8 \mathrm{~h} 00$ \\
Total & $\mathbf{2 3}$ & $\mathbf{2 1 h 3 0}$ \\
\hline número de entrevistados foi estabelecido visando o entendimento da estrutura de \\
\hline tribuição de carga e os papéis desempenhados pelos agentes, os fluxo de informações e
\end{tabular}


de materiais, assim como o levantamento dos atributos de distribuição de carga mais relevantes sob o ponto de vista dos representantes das empresas deste estudo de caso. Desta forma, foram entrevistados executivos da área de logística em diferentes cargos, supervisores, gerentes e diretores, assim como, analistas de informações gerenciais e motoristas.

Além das entrevistas, durante o trabalho de campo foram acompanhadas entregas a partir do CD do Operador logístico A e da Transportadora B, que teve por objetivo coletar informações adicionais e identificar particularidades dos atributos (Quadros 5 e 6).

Quadro 5 - Acompanhamento de entrega na RMSP - Estudo de caso A

\begin{tabular}{lcc}
\hline \multicolumn{1}{c}{$\begin{array}{c}\text { Acompanhamento de entregas na } \\
\text { RMSP - Estudo de caso A }\end{array}$} & Dados & Duração \\
\hline $\begin{array}{l}\text { Viagens } \\
\text { (Origem e retorno no CD do Operador) }\end{array}$ & 6 viagens & Mínimo: $5 \mathrm{~h}$ \\
Entregas & 17 pontos de & Máximo: $7 \mathrm{~h}$ \\
$\begin{array}{l}\text { (Chegada no cliente, estacionamento, } 20 \mathrm{~min} \\
\text { entrega da } \\
\text { conferência e devolução do canhoto } 1 \mathrm{CD}, 2\end{array}$ & Máximo: $5 \mathrm{~h}$ \\
assinado) & shopping, 14 lojas & \\
\hline
\end{tabular}

Quadro 6 - Acompanhamento de entrega na RMSP - Estudo de caso B

\begin{tabular}{lcc}
\hline $\begin{array}{l}\text { Acompanhamento de entregas na } \\
\text { RMSP - Estudo de caso B }\end{array}$ & Dados & Duração \\
\hline Viagens & 4 viagens & Mínimo: $4 \mathrm{~h}$ \\
(Origem e retorno no CD do Operador) & Máximo: $6 \mathrm{~h}$ \\
Entregas & 12 pontos de & Mínimo: 20min \\
$\begin{array}{l}\text { (Chegada no cliente, estacionamento, venda: } 1 \mathrm{CD}, 3 \\
\text { entrega da NF, descarregamento, lojas em shopping }\end{array}$ & Máximo: $2 \mathrm{~h} 30$ \\
$\begin{array}{l}\text { conferência e devolução do canhoto } \\
\text { assinado) }\end{array}$ & & \\
\hline
\end{tabular}

Assim, os levantamentos de dados realizados por meio das 38 entrevistas e acompanhamentos de entrega em 29 pontos de venda, totalizando mais de $90 \mathrm{~h}$ de trabalho de campo, contribuíram para o entendimento dos processos e dos fluxos de informação e material na distribuição de carga dessas empresas. 
Após o levantamento dos atributos de distribuição de carga e informações junto aos Embarcadores, Operadores Logísticos, Transportadores e Clientes, os estudos de caso foram descritos e discutidos individualmente, analisando-se os relatos, observações, informações e indicadores obtidos. Com base nos resultados encontrados e conclusões entre os casos, obteve-se também a validação dos atributos utilizados na construção dos protocolos de pesquisa para a coleta de dados estatísticos.

\subsection{PROCEDIMENTOS METODOLÓGICOS DA COLETA DE DADOS}

O procedimento adotado para a coleta de dados foi a aplicação de um questionário estruturado específico para os principais agentes prestadores de serviços logísticos e que realizam ou terceirizam a operação logística (desde a coleta à entrega ao cliente final): Operador Logístico e Transportador.

Para a operacionalização da coleta de dados, utilizou-se a plataforma web Survey Monkey $e$ as respostas foram armazenadas em um banco de dados de acesso restrito ao pesquisador. O link da pesquisa foi enviado por e-mail para os representantes de empresas cujos contatos fazem parte de um banco de dados atualizado do Projeto FAPESP $19271-9$ e de entidades representativas dos setores envolvidos, a Associação Brasileira dos Operadores Logísticos (ABOL) e o Sindicato dos Transportadores de Carga de São Paulo (SETCESP), no período de setembro a novembro de 2013.

Dada a dificuldade em medir o tamanho da população de interesse, Operador logístico e Transportador, que realizam transporte de carga na RMSP, a população foi considerada infinita e a amostragem foi feita por conveniência. A unidade amostral é o respondente, pois o objetivo é identificar, por meio das percepções individuais, a visão agregada dessas empresas prestadoras de serviços logísticos.

A Tabela 4 mostra a taxa de resposta obtida por prestador de serviço logístico. 
Tabela 4 - Taxa de resposta por prestador de serviços logísticos

\begin{tabular}{lcccc}
\hline \multirow{2}{*}{ Questionários } & \multicolumn{2}{c}{ Operador logístico } & \multicolumn{2}{c}{ Transportador } \\
& Número & $\%$ & Número & $\%$ \\
\hline Total & 43 & 100.00 & 6.500 & 100.00 \\
Respondidos & 30 & 69.76 & 138 & 2,12 \\
Incompletos & 5 & 11.63 & 40 & 0,62 \\
Não considerados & 1 & 0.02 & 3 & 0.05 \\
Válidos & $\mathbf{2 4}$ & $\mathbf{5 5 . 8 1}$ & $\mathbf{9 5}$ & $\mathbf{1 , 5}$ \\
\hline
\end{tabular}

Conforme mostra a Tabela 4, a pesquisa obteve um total de 24 questionários válidos para operador logístico e 95 questionários válidos para transportador. Nota-se que aproximadamente um terço dos respondentes dos transportadores não concluíram o preenchimento do questionário. Além disso, quatro questionários foram excluídos da base de dados, pelos seguintes motivos: o respondente não trabalha no setor de logística da empresa ou trabalha em empresa de e-commerce.

Os resultados do levantamento de dados correspondentes aos 119 questionários válidos coletados neste trabalho foram tabulados, e a análise estatística descritiva dos dados da pesquisa será descrita a seguir.

\subsection{PROCEDIMENTOS METODOLÓGICOS DA ANÁLISE DOS DADOS}

Serão utilizadas técnicas estatísticas descritivas univariadas, como medidas de posição e dispersão, apresentadas em forma de tabelas e gráfico, para a análise dos dados levantados na pesquisa. Desta forma, pretende-se obter um melhor entendimento e relevância dos atributos da distribuição de carga na cidade de São Paulo e sua complexidade.

\subsection{CONSIDERAÇÕES FINAIS SOBRE A METODOLOGIA}

O Quadro 7 sintetiza as etapas da estrutura metodológica descrita nos tópicos anteriores, visando atender o objetivo proposto desta dissertação. 
Quadro 7 - Síntese dos resultados propostos

\begin{tabular}{ll}
\hline \multicolumn{1}{c}{ Método } & \multicolumn{1}{c}{ Resultados } \\
\hline a) Revisão da & Identificar os papéis fundamentais dos agentes, \\
bibliografia e estudo & Embarcador, Operador Logístico, Transportador e \\
de caso & Cliente, assim como os atributos de distribuição urbana \\
& de carga que podem impactar o desempenho logístico \\
& desses agentes na distribuição de carga na RMSP. \\
b) Levantamento de & Identificar a relevância dos atributos levantados na \\
dados & literatura e nos estudos de caso, sob a ótica dos \\
& prestadores de serviços logísticos, Operador logístico e \\
& Transportador, que atuam na distribuição de carga na \\
& RMSP.
\end{tabular}




\section{RESULTADOS: ESTUDOS DE CASO A E B}

Este tópico tem o objetivo de apresentar e discutir os dados levantados durante o trabalho de campo com as empresas participantes dos dois estudos de caso, Embarcador, Operador logístico, Transportador e Cliente, no período de setembro de 2013 a janeiro de 2014.

Algumas informações serão apresentadas de forma agregada ou por meio de dados aproximados, por conta das políticas de sigilo e confidencialidade das empresas envolvidas, como, por exemplo, o faturamento anual, participação percentual no faturamento dos embarcadores e clientes, e histórico dos indicadores de desempenho logístico e da movimentação de mercadoria.

Ao longo da apresentação dos dados, os pontos relevantes para a pesquisa, referentes aos papéis desempenhados pelos agentes, os atributos de distribuição urbana de carga e indicadores de desempenho das empresas, serão discutidos. Concluindo os estudos de caso, a análise cruzada e a discussão dos resultados serão apresentadas nos dois estudos à luz da revisão de literatura.

\subsection{CASO A - APRESENTAÇÃO DO OPERADOR LOGÍSTICO A E TRANSPORTADOR A}

Operador logístico A trata-se de uma empresa de capital nacional, fundada em 2006, com faturamento bruto no ano de 2012 acima de $R \$ 2,4$ milhões, possui 30 funcionários e atende a diversas regiões do território nacional atuando nos seguintes segmentos varejistas: cosméticos, medicamentos e produtos hospitalares (agulhas, seringas, etc.), produtos de higiene e limpeza, entre outros correlatos.

Com sede na cidade de Barueri-SP, o Operador logístico A possui um centro de distribuição próprio, onde recebe de seus 15 clientes (embarcadores) os produtos para armazenagem e posterior distribuição ao mercado varejista, composto por 
aproximadamente 900 lojas e 10 centros de distribuição localizados na região metropolitana de São Paulo. Cerca de $98 \%$ da carga distribuída é fracionada e seis clientes contratam apenas o serviço de transporte.

Com relação aos principais serviços logísticos prestados aos clientes, observam-se serviços de armazenagem, colocação de etiquetas, embalagem, gerenciamento de estoques e gerenciamento de transporte. Esses serviços diferem por cliente e, para cada cliente, existe um procedimento padrão para atender às suas especificidades. Para o melhor gerenciamento desses serviços, a Empresa utiliza Sistema de Gerenciamento de Armazém (ou Warehouse Management System - WMS) e de Gerenciamento de Transporte (ou Transportation Management System - TMS), além de Troca Eletrônica de Dados (ou Eletronic Data Interchange - EDI) com os seus clientes e extranet com as transportadoras para verificar a posição (status) de entrega dos produtos.

O Operador logístico A realiza, em média, quatro embarques (únicos) diários para cerca de 30 destinatários. Cerca de 10\% das entregas são para centros de distribuição de grandes drogarias. Para realizar a distribuição física, o Operador logístico A terceiriza o serviço para 15 transportadoras, sendo que seis destas prestam serviços de transporte exclusivo para o Operador logístico $A$, dentro do Estado de São Paulo, e as demais atendem às regiões do território nacional. O lead time de entrega é de 24 horas.

O Transportador A é responsável pelo transporte exclusivo de carga na RMSP, litoral e interior do Estado de São Paulo, além do transporte para os estados do Rio de Janeiro e Minas Gerais. Atua há 8 anos no transporte de cargas fracionadas e em 2012 realizou um faturamento bruto inferior a R 240 mil, sendo 90\% desse faturamento provenientes dos serviços prestados ao Operador logístico $A$. O Transportador A contrata e administra o serviço de seis motoristas dedicados no transporte de carga na RMSP, com frota terceirizada composta por veículos de diversas capacidades, sendo os veículos menores, como fiorinos e vans, os mais utilizados na entrega aos pequenos e médios varejos. Além desses veículos, a empresa utiliza caminhão truck quando os destinos são os centros de distribuição das grandes drogarias. 
O Operador logístico A possui Manual de Qualidade e Procedimentos Operacionais Padronizados (POP's) em conformidade com as Boas Práticas de Distribuição, Armazenagem e Transporte de Produtos e Norma UM 9001:2008.

A seguir serão apresentados, de forma sucinta, os procedimentos de armazenagem e transporte, que são as operações fundamentais executadas por esse operador logístico para os dois principais clientes.

- POP de Armazenagem: estabelece a sistemática de execução das atividades de recebimento, estocagem, derrubada, picking, expedição, tratamento de avarias, devolução dos produtos e inventário.

- POP de Transporte: estabelece a metodologia de trabalho na execução e no tratamento de anomalias das atividades de coleta do produto no armazém do operador logístico e distribuição. Além disso, define os critérios para seleção e qualificação de transportadora (preço do frete, custo global de transporte e requisitos de qualidade), assim como os procedimentos de limpeza e higienização dos veículos.

Visando garantir a entrega na data e horário agendados, dentro do lead time de 2 dias, o Operador logístico A possui um fluxo de atendimento ao pedido com prazos definidos e alinhados com seus clientes que apresenta as seguintes regras: o corte de pedido é feito às $14 \mathrm{~h}$, a programação e roteirização é enviada para transportadora até $17 \mathrm{~h}$, os produtos são separados até às $22 \mathrm{~h}$ e a expedição ocorre a partir das 7 h30 do dia seguinte.

Além disso, a equipe de gestão de entrega monitora o andamento das entregas por meio de rádio e, no caso de anomalia no processo, comunica imediatamente o embarcador buscando eliminar o risco de devolução de carga junto ao cliente. 


\subsection{CASO A - APRESENTAÇÃO DOS EMBARCADORES E SEUS CLIENTES VAREJISTAS}

Dois dos principais clientes do Operador logístico A, Embarcadores A1 e A2, representam juntos mais de $50 \%$ do faturamento do Operador logístico $A$, sendo que cerca de $80 \%$ deste é referente ao volume entregue exclusivamente na RMSP, ou $40 \%$ do faturamento total do Operador logístico A, e são caracterizados a seguir:

O Embarcador A1 é uma empresa multinacional fabricante de utensílios e alimentos para a puericultura. Todo o portfólio de produto, com aproximadamente 100 itens, é importado de diversos países. A importação, nacionalização e transporte do porto até o $C D$ do Operador logístico $A$ é feita por um prestador de serviço contratado pela empresa B1. O lead time dessa operação é de aproximadamente quatro meses, desde a fabricação, transporte marítimo, nacionalização e transporte rodoviário. Em média, são importados quatro containers de 40 pés por mês, sendo a distribuição nacional dos produtos feita exclusivamente pelo Operador logístico A.

A Embarcador A2 é uma empresa de capital nacional, fabricante de produtos de higiene e beleza, localizada fora do estado de São Paulo. Com 20 anos de mercado, a Empresa A distribui seus produtos para mais de 300 pontos de venda na região metropolitana de São Paulo e, desde 2012, vem migrando o modelo de atendimento via canal direto para canais indiretos de distribuição, por meio de distribuidores regionais. Atualmente, $60 \%$ dos pontos de venda são atendidos por distribuidores, $20 \%$ são atendidos através dos CDs de grandes redes de drogaria e $20 \%$ são lojas de pequeno e médio porte atendidos diretamente. O Operador logístico A é o responsável pelo transporte de carga conforme os canais de distribuição adotados pelo Embarcador A2.

No estudo de caso, os clientes dos embarcadores, Clientes A1a; A1b e A2a; A2b, também foram entrevistados. O Quadro 8 apresenta, de forma resumida, algumas características desses clientes: 
Quadro 8 - Características dos Clientes - Estudo de caso A

\begin{tabular}{|c|c|c|}
\hline Embarcador & Cliente & Características \\
\hline \multirow[t]{2}{*}{ Embarcador A1 } & Cliente A1a & $\begin{array}{l}\text { - } 3 \text { CDs na RMSP que atendem } 140 \text { pontos de } \\
\text { venda no estado de São Paulo. } \\
\text { - CD da Zona Central com } 90 \text { funcionários. } \\
\text { - Recebe } 40 \quad \text { veículos/dia de diversos } \\
\text { embarcadores. } \\
\text { - Entregas são todas agendadas. } \\
\text { - Janela de entrega das 9h às } 12 \mathrm{~h} \text {. } \\
\text { - Expede } 24 \text { veículos/dia - caminhões e VUCs } \\
\text { - Possui local para carga e descarga. }\end{array}$ \\
\hline & Cliente A1b & $\begin{array}{l}\text { - } 1 \text { CD que atende todo o Brasil. } \\
\text { - } \quad \text { Estado de São Paulo: } 85 \% \text { do volume expedido. } \\
\text { - } \quad \text { RMSP: } 70 \% \text { do volume expedido. } \\
\text { - } \text { CD com } 70 \text { funcionários. } \\
\text { - } \text { Entregas são todas agendadas. } \\
\text { - Janela de entrega das } 9 \mathrm{~h} \text { às } 14 \mathrm{~h} \text {. } \\
\text { - } \text { Expede } 15 \text { veículos/dia - caminhonetes e VUCs } \\
\text { - } \text { Possui local para carga e descarga. } \\
\\
\text { Paulo } 100 \text { pontos de venda no Estado de São }\end{array}$ \\
\hline \multirow[t]{2}{*}{ Embarcador A2 } & Cliente A2a & $\begin{array}{l}\text { - Possui uma loja na RMSP. } \\
\text { - Tem } 10 \text { funcionários. } \\
\text { - Recebe entregas todos os dias em horário } \\
\text { comercial. } \\
\text { - Não tem local para carga e descarga. }\end{array}$ \\
\hline & Cliente $\mathrm{A} 2 \mathrm{~b}$ & $\begin{array}{l}\text { - Possui duas lojas na RMSP. } \\
\text { - Tem } 10 \text { a } 15 \text { funcionários por loja. } \\
\text { - Recebe entregas todos os dias em horário } \\
\text { comercial. } \\
\text { - Não tem local para carga e descarga. }\end{array}$ \\
\hline
\end{tabular}

Conforme mostra o Quadro 8, os Clientes A1a e A1b são CDs de grandes redes de drogarias, responsáveis pelo abastecimento das lojas da rede no estado de São Paulo. Por outro lado, os clientes A2a e A2b são lojas de varejo, atendidas diretamente pelo Operador logístico $A$, pois a região na qual se encontram não é atendida por distribuidor. Dada a relevância das Empresas A1 e A2 no faturamento do Operador logístico A na RMSP e para a importância do estudo da distribuição física de carga na RMSP, as próximas seções se referem às operações logísticas dedicadas aos Embarcadores A1 e A2. 


\subsection{CASO A - PAPÉIS DOS AGENTES E A ESTRUTURA DE DISTRIBUIÇÃO}

De acordo com as informações coletadas por meio de entrevistas realizadas com os agentes participantes deste estudo e observações de campo, pôde-se obter a estrutura da distribuição de carga (Figura 17).

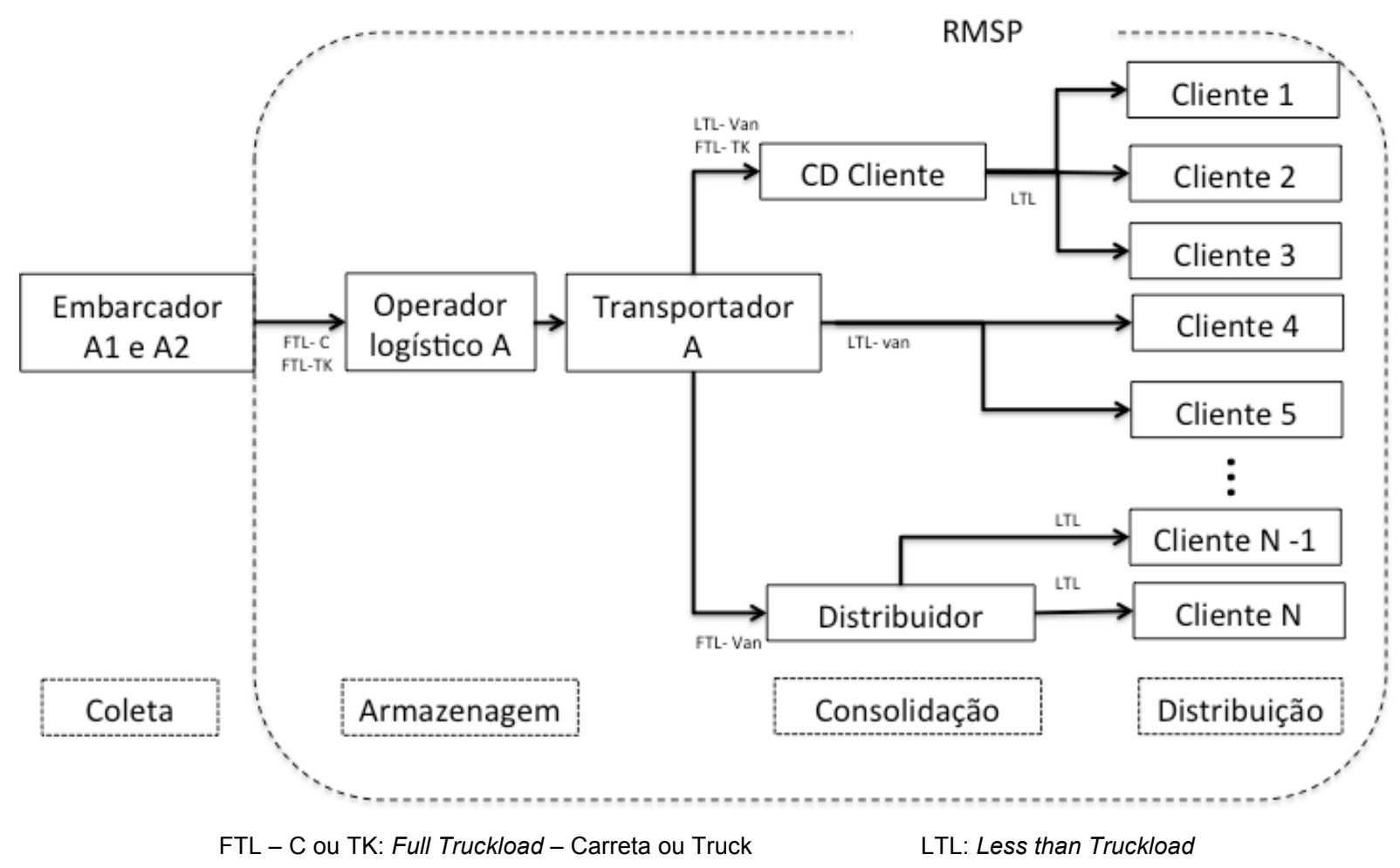

Figura 17 - Estrutura da distribuição de carga na RMSP-empresa A

A Figura 17 mostra os agentes e o fluxo de carga. Os Embarcadores A1 e A2 são responsáveis pela entrega da carga no Operador $A$, que está localizado dentro da RMSP (linha pontilhada). A transportadora que realiza a coleta é contratada pelos Embarcadores. Após a coleta, a carga é armazenada no CD do Operador logístico A, que é o prestador de serviços logísticos responsável pela gestão de armazenagem e transporte dos produtos para os clientes. O Transportador A é contratado pelo Operador logístico A e realiza as entrega aos Clientes diretamente no destino final, ou nos CDs de grandes clientes ou de distribuidores (apenas no caso do Cliente A2).

Conforme esquema apresentado na Figura 17, nota-se que os Embarcadores A1 e A2 distribuem seus produtos por meio de instalações logísticas de terceiros, 
Operador logístico A, Centros de Distribuição próprios e Distribuidor. O transporte da carga dos Embarcadores A1 e A2 até o Operador logístico A é feito via carga lotação em veículos maiores (FTL Carretas ou Trucks), otimizando o frete de longa distância. A distribuição pode ser feita via carga fracionada (LTL) do Operador logístico A para os estabelecimentos do varejo e CD distribuidores, sendo vans e Fiorinos os veículos mais utilizados. No caso de entrega em CDs de grandes redes de farmácia, o transporte é feito com carros dedicados, com carga completa (FTL Trucks ou Vans).

Como estratégia de distribuição, o embarcador utiliza o operador logístico como uma instalação intermediária de armazenagem dos produtos. O Operador logístico A, localizado perto do mercado consumidor, é responsável pelas operações de armazenagem e transporte dos produtos para os clientes. Desta forma, o Operador logístico A realiza a separação do produto em estoque e o transporte conforme carteira de pedidos enviada pelo embarcador, garantindo maior agilidade no atendimento das necessidades do cliente, como janela de entrega e horário agendado para recebimento.

O Operador logístico A é o provedor de serviços logísticos central desta estrutura de distribuição, gerenciando e executando de forma coordenada as atividades de armazenagem, gerenciamento de estoque e gestão do pedido. Ele é o responsável por reportar mensalmente o desempenho da entrega e, caso necessário, buscar ações coordenadas juntos aos demais agentes, visando a eficiência do processo.

A contratação de transportadora, negociação de frente e monitoramento da entrega são papéis também desempenhados pelo Operador logístico A.

A Transportadora A responsável pelo transporte de carga na RMSP, utiliza veículos menores no caso de entrega direta às lojas do varejo, que demandam uma maior frequência de entrega de pequenos volumes, comprometendo a taxa de ocupação do veículo. Por outro lado, oferecem maior flexibilidade quanto aos horários de recebimento, sem janelas de entrega fixas e, na maioria da vezes, a entrega pode ser feita em horário comercial.

O transporte também pode ser realizado indiretamente por meio de remessa de carga completa em veículos maiores para os centros de distribuição dos clientes ou 
distribuidores. A partir deste ponto, a responsabilidade referente à integridade e transporte do produto ao ponto de venda passa a ser do CD do cliente ou do distribuidor.

Os CDs das grandes redes consolidam a carga de diversos embarcadores, armazenam os produtos por um curto período de tempo, e são responsáveis pela distribuição e transporte dos produtos às drogarias da rede.

O Distribuidor é responsável por abastecer os pequenos varejos e oferece consultoria e serviços como: treinamento da equipe de vendas e promoção, lay-out da loja e exposição dos produtos, força de vendas e equipe promocional. Além disso, é responsável pela comercialização e atendimento ao cliente dentro de sua área de atuação. Operacionalmente, viabiliza a comercialização de lotes menores e com agilidade de atendimento, diminuindo o lead time do pedido.

Os Clientes A1a e A1b são CDs de grandes redes de farmácia e se preocupam mais com os atributos como janela de entrega, agendamento, requisitos específicos para o recebimento de mercadoria, comprometimento na entrega e carros dedicados. Esses clientes têm maior poder de influência na cadeia dos que os Clientes A2a e A2b devido ao grande volume transacionado.

No caso dos clientes que não fazem parte de redes varejistas, os atributos de distribuição que mais são percebidos como problemas estão relacionados ao volume de entrega, ocupação de veículo, flexibilidade, comprometimento de entrega e local adequado para carga e descarga.

\subsection{CASO A - ATRIBUTOS DE DISTRIBUIÇÃO DE CARGA E INDICADORES DE DESEMPENHO LOGÍSTICO}

Para os Embarcadores A1 e A2, as operações realizadas na distribuição de carga são apenas a armazenagem e transporte. Portanto, os atributos de distribuição de carga se referem às atividades internas ao CD (recebimento, armazenagem, processamento de pedidos e expedição) e ao transporte. 
Com relação às atividades no $C D$, os principais problemas segundo o Operador logístico A referem-se aos atributos logísticos: falha no procedimento de conferência no recebimento e no embarque, o não cumprimento do horário de corte para recebimento da carteira de pedido e atraso na expedição de carga.

Todas as entregas são programadas, sendo que a maioria das entregas nas lojas pode ser feita em horário comercial, ao passo que os CDs definem janelas de entrega que podem variar, por exemplo, até $11 \mathrm{~h}, 13 \mathrm{~h}$ ou $14 \mathrm{~h}$. As entregas em lojas localizadas em shoppings centers devem ser feitas até 10 horas da manhã.

A eficiência da distribuição é monitorada através do indicador de desempenho de entrega, pedido entregue na data acordada, reportado mensalmente pelo operador logístico nas reuniões individuais com os Embarcadores. Os principais problemas na distribuição que mais interferem no bom desempenho desse indicador são: a) demora na conferência na entrega, falta de infraestrutura nas vias públicas para estacionar; falta de área para carga e descarga e vias estreitas b) assimetria de informação e falta de comunicação direta com o destinatário; e c) congestionamento, e falta de segurança em áreas de risco.

A Tabela 5 apresenta o desempenho da entrega em 2012 para os dois Embarcadores (Empresas A1 e A2).

Tabela 5 - Desempenho de entrega em 2012

\begin{tabular}{cccccccc}
\hline Embarcador & $\begin{array}{c}\text { Total de } \\
\text { Entregas }\end{array}$ & Varejo & CD & $\begin{array}{c}\text { No } \\
\text { prazo }\end{array}$ & Atraso & Devolução & OTIF \\
\hline A1 & 824 & 789 & 35 & 803 & 8 & 13 & $97,7 \%$ \\
A2 & 894 & 546 & 348 & 867 & 6 & 21 & $97,0 \%$ \\
Total & 1718 & 1335 & 383 & 1670 & 14 & 34 & $97,2 \%$ \\
\hline
\end{tabular}

Conforme estratificação das causas baseadas no levantamento dos dados de 2012 realizado pelo Operador logístico, destaca-se a falta de espaço como a principal causa de devolução de produtos pelas empresas que têm $C D$, seguida de falta de pedido (ou pedido cancelado). No caso das lojas do varejo, a principal causa é a falta de pedido (ou pedido cancelado). Esses motivos estão relacionados aos atributos de colaboração, como falta de comunicação e assimetria de informação entre os Embarcadores, Operador Logístico e Clientes. Os atrasos ocasionados estão relacionados aos atributos destacados anteriormente: demora na conferência 
da carga no cliente e falta de local adequado para estacionamento, carga e descarga e congestionamento.

Os Clientes A1 e A2, por sua vez, têm uma boa avaliação da entrega, apesar de não possuírem indicadores estruturados, e apontam a agilidade de entrega, ou seja, o lead time do pedido como o principal atributo percebido.

O Operador logístico e o Transportador A também destacam a falta de confiabilidade durante o recebimento dos produtos por parte dos clientes (atributo de colaboração). $\mathrm{Na}$ maioria dos clientes, a conferência é feita por meio da abertura de $100 \%$ das caixas para contagem unitária. Este fato foi constatado na maioria das entregas acompanhadas. Por exemplo, a entrega no CD do Cliente A1a teve a duração total de 5 horas, desde a entrega da nota final e saída do estabelecimento, sendo 3 horas apenas para a conferência. Por conta da demora no recebimento, as entregas em CDs e em lojas com histórico semelhante ao Cliente A1a são feitas com carro dedicado ou com baixa ocupação, com no máximo duas entregas por carro.

Ainda sobre aspectos de colaboração, o Operador logístico A e o Transportador A consideram a falta de flexibilidade quanto aos requisitos de entrega por parte dos clientes, principalmente nos CDs das drogarias, como um dos principais problemas na distribuição. Segundo o Operador logístico A, esses CDs recebem somente cargas unitizadas com quatro pallets contendo quatro skus por pallet, com stretch film e a altura da carga deve ser nivelada com a doca de recebimento.

Falta também comunicação aberta entre a área de logística do CD com o embarcador. Normalmente, o contato é feito entre a área de compras do cliente (destinatário final) e a área de vendas do Embarcador. Ainda, segundo o entrevistado, "isso custa caro porque tenho que colocar pessoal qualificado para fazer essas entregas e levantar as possibilidades para flexibilização nas entregas segundo às exigências deste destinatário".

O entrevistado relatou ainda a falta de compartilhamento de informação por parte dos embarcadores em relação aos clientes finais. "Se o destinatário acusa demora no recebimento da mercadoria, o SAC é acionado e o cliente entra em contato com o operador logístico". Normalmente o embarcador faz a venda, estabelece o dia de entrega (normalmente em 24 horas), não avisa se há janela de entrega, se terá 
necessidade de uma pessoa extra para descarga, entre outras informações que se fossem compartilhadas com o operador logístico poderiam ajudar no gerenciamento da distribuição da carga por meio das transportadoras. Além disso, o embarcador às vezes não imprime o boleto de pagamento junto à nota fiscal, fazendo com que esta tarefa seja do operador logístico.

Nesse sentido, o Operador logístico A considera a assimetria de informação com o destinatário o principal problema da distribuição de carga. A falta de informação da real necessidade do cliente final e das condições de entrega faz com que ocorram atrasos nas entregas e devoluções de pedidos.

A assimetria de informação é também apontada pelos Embarcadores A1 e A2 como um dos principais problemas que impactam o desempenho de entrega. No entanto, essas empresas destacam que a falha principal está no fluxo interno de comunicação dessas empresas, especificamente entre a área comercial e o faturamento, podendo ocasionar atrasos no faturamento e no envio da carteira de pedidos para o operador logístico. Logo, o lead time de entrega acaba sendo comprometido, gerando a necessidade de entrega em caráter de urgência ou com carro dedicado.

Com relação aos atributos regulatórios, a política de restrição de circulação de caminhão no centro expandido já foi endereçada com a frota contratada composta principalmente por veículos menores (Fiorinos e Vans), segundo o operador logístico e o transportador. Embora apenas 10\% das entregas sejam programadas, o uso de veículos menores ou carros dedicados para entregas em CDs possibilitam o atendimento às zonas de restrição de circulação de caminhão e ao rodízio de veículos, não impactando o atendimento das janelas de entrega de até 6 horas.

Outro aspecto observado na maioria das entregas, foi a falta de local regulamentado para carga e descarga, principalmente em áreas remotas, ou vaga para veículo de passeio disponível e próxima ao ponto de venda. Nesses casos, o motorista geralmente usa rotas alternativas para encontrar uma vaga para estacionar e descarregar as mercadorias. Isso certamente acarreta um aumento no tempo gasto com a entrega e a possibilidade de subsequentes atrasos nas entregas. 
Os atributos ambientais, como necessidade de uso de bio combustível e atendimento às normas para controle de emissões características não foram apontadas como relevantes pelos entrevistados em geral. Talvez isso aconteça porque ainda não é uma exigência dos clientes e tão pouco uma prioridade para as empresas de transporte frente aos demais problemas a serem enfrentados na região metropolitana.

Durante o acompanhamento das entregas também foi constatado que os congestionamentos acabam por comprometer a rota programada, uma vez que os motoristas precisam alterar o trajeto e até mesmo a sequência de estabelecimento atendidos, visando recuperar o tempo gasto no deslocamento e garantir a entrega dos pedidos. Este foi um dos atributos apontados por todos os agentes entrevistados que certamente impactam o desempenho da entrega, ocasionando atraso ou o não atendimento da janela de entrega.

O seguro da carga é responsabilidade do Operador logístico A que exige o uso de trava de segurança de acionamento interno em todos os veículos. Segundo o Operador logístico A, apesar de não ter ocorrido nenhum caso de roubo de carga no último ano, por prevenção, geralmente os veículos utilizam vagas em estacionamentos privados para entregas em regiões de risco (Guarulhos e Zona Sul), sendo o valor reembolsado ao motorista. No entanto, na maioria dos casos não há estacionamento próximo ao local de entrega, e o transportador tem que contratar um auxiliar de transporte (ajudante) para agilizar a descarga e ajudar na segurança da carga para evitar saques.

Segundo os entrevistados, Operador Logístico A e o Transportador A, os demais atributos de risco, como greves, manifestações e enchentes constituem também fatores que interferem no desempenho logístico, embora não tão relevantes quando comparados aos já apresentados.

O Quadro 9 sintetiza os atributos de distribuição levantados no estudo de caso A percebidos por cada tipo de empresa. 
Quadro 9 - Síntese dos atributos de distribuição - Estudo de caso A

\begin{tabular}{|c|c|c|c|c|}
\hline Atributos & Embarcador & $\begin{array}{l}\text { Operador } \\
\text { Logístico }\end{array}$ & Transportador & Cliente \\
\hline \multicolumn{5}{|l|}{$\begin{array}{l}\text { 1. Atributo logístico } \\
\text { frequência de entrega }\end{array}$} \\
\hline janela de entrega & & $x$ & $x$ & \\
\hline $\begin{array}{l}\text { local adequado para carga e descarga } \\
\text { filas }\end{array}$ & \multicolumn{3}{|c|}{ filas } & \\
\hline prazo de entrega & $x$ & & & $x$ \\
\hline tempo de carga e descarga & & & $x$ & \\
\hline $\begin{array}{l}\text { quantidade entregue ou consumo sazonal } \\
\text { quantidade e tipo de veículos }\end{array}$ & \multicolumn{3}{|c|}{ quantidade e tipo de veículos } & \\
\hline número de entregas & & $x$ & $x$ & \\
\hline ocupação do veículo & & $x$ & & \\
\hline $\begin{array}{l}\text { custo do transporte } \\
\text { distância percorrida }\end{array}$ & \multicolumn{3}{|c|}{ distância percorrida } & \\
\hline \multicolumn{5}{|l|}{ 2. Atributos de colaboração } \\
\hline compartilhamento de informações & $x$ & $x$ & $x$ & \\
\hline compartilhamento de ganhos e custos & & $x$ & & \\
\hline comprometimento & & $x$ & $x$ & \\
\hline confiabilidade & & $x$ & $x$ & \\
\hline flexibilidade & & $x$ & $x$ & \\
\hline \multicolumn{5}{|l|}{ acordos logísticos } \\
\hline soluções conjuntas & $x$ & $x$ & & \\
\hline \multicolumn{5}{|l|}{ 3. Atributos regulatórios } \\
\hline $\begin{array}{l}\text { restrição de circulação por horário e } \\
\text { tamanho de veículo }\end{array}$ & & $x$ & $x$ & \\
\hline $\begin{array}{l}\text { regulamentação de vaga para carga e } \\
\text { descarga }\end{array}$ & & $x$ & $x$ & \\
\hline $\begin{array}{l}\text { 4. Atributos ambientais } \\
\text { emissão de poluentes } \\
\text { tipo de combustível }\end{array}$ & & & & \\
\hline \multicolumn{5}{|l|}{ 5. Atributos de risco } \\
\hline congestionamento & $x$ & $x$ & $x$ & $x$ \\
\hline roubo de carga (zona de risco) & & $x$ & $x$ & \\
\hline
\end{tabular}

Como mostra o Quadro 9, o Operador logístico A e o Transportador A compartilham a percepção em relação a maioria do atributos de distribuição. As exceções ocorrem quando o atributo se refere à uma abordagem mais sistêmica e voltado a eficiência do global da distribuição, foco central do operador, tais como: a) atributos logísticos: 
quantidade entregue ou consumo sazonal, número de entregas, ocupação do veículo e custo do transporte e b) atributos de colaboração: compartilhamento de ganhos e custos e soluções conjuntas.

Além disso, esses atributos logísticos e de colaboração demandam uma gestão de interfaces entre os agentes: Embarcador A, Operador Logístico A e Transportador A. O Operador logístico A, por ser o intermediário nesse canal de distribuição, poderia exercer esse papel de forma mais eficiente, ou seja, o seu papel poderia se estender até ao gerenciamento do relacionamento entre as partes envolvidas, porém, esse gerenciamento pode se apresentar como uma barreira à medida que os Embarcadores A1 e A2 não disponibilizam um canal direto de comunicação e não compartilham as estratégias de distribuição e comercialização com o Operador logístico A.

Por outro lado, a preocupação com prazo de entrega é o atributo logístico mais citado pelos Embarcadores A1 e A2 e pelos Clientes A1 e A2, que demandam mais agilidade da cadeia de distribuição por conta dos baixos níveis de estoque e volumes de entrega cada vez menores.

Todos os agentes entrevistados não apontaram os atributos ambientais como relevantes no contexto do estudo. Provavelmente por não se destacarem frente aos demais problemas que os prestadores de serviços logísticos enfrentam na distribuição de carga na RMSP ou mesmo por não serem exigidos pelos Embarcadores ou Clientes.

Os atributos regulatórios percebidos pelo Operador logístico A e Transportador A não são destacados pelos Embarcadores e Clientes, provavelmente por entenderem que a restrição de circulação de veículos e falta de vagas regulamentadas para carga e descarga são problemas que devem ser endereçados pelos prestadores de serviços logísticos.

Pelo mesmo motivo, em se tratado de atributos de risco, percebe-se que o roubo de carga é um problemas destacado apenas pelos prestadores de serviços logísticos. No entanto, o congestionamento é percebido como um problema unânime para todos os agentes. 


\subsection{CASO B - APRESENTAÇÃO DO OPERADOR LOGÍSTICO B E TRANSPORTADOR B}

O Operador logístico B trata-se de uma empresa multinacional, operando no Brasil desde 1998. Com aproximadamente 7 mil funcionários, realiza suas operações por meio de centros de armazenagem e distribuição em 40 cidades atendendo diversas regiões do território nacional, sendo mais de $60 \%$ dos negócios concentrados na região Sudeste.

O total de cargas coletadas e expedidas por dia é de, respectivamente, 4,5 mil metros cúbicos e 10 mil volumes. Além da abrangência territorial, possui destacada atuação nos setores automobilístico, industrial, consumo e varejo, farmacêutico, químico, energia e tecnologia, oferecendo aos seus clientes (embarcadores) serviços de armazenagem e atendimento ao pedido, soluções e gerenciamento de transportes multimodais e distribuição de carga, gestão integrada da cadeia de suprimentos, logística reversa, embalagem e reembalagem, montagem de Kits e embalagens especiais, e lançamento de produtos (envio de amostras).

No entanto, neste estudo de caso serão analisadas somente duas unidades do Operador logístico B, localizadas no interior de São Paulo. Cada uma dessas unidades presta serviços logísticos de forma dedicada e exclusiva para um dos embarcadores abordados no estudo de caso B.

Dentre os principais serviços oferecidos pelo Operador logístico B para os dois embarcadores abordados neste estudo de caso destacam-se: as operações de cross-docking e os serviços de armazenagem. Isso engloba, por exemplo, o gerenciamento de estoque e pedido, soluções de transporte e distribuição, padronização e detalhamento dos processos, gerenciamento da qualidade e performance dos prestadores de serviços de transporte e distribuição, além de serviços de pós-venda, tais como, logística reversa, reclamações e atendimento ao cliente.

Ressalta-se ainda que, o Operador logístico B não possui motoristas no quadro de funcionários e, tão pouco, frota própria. Logo, as operações relacionadas à movimentação física da carga são terceirizadas aos prestadores de serviços de 
transporte. Isto mostra, conforme Stenfasson (2006), que o Operador logístico B assume mais um papel de 4PL do que 3PL.

Esses serviços diferem por cliente e existe um procedimento padrão para atender às suas especificidades, definindo os indicadores de desempenho, o nível de serviço contratado, assim como o formato e frequência de apresentação dos resultados.

Para o melhor gerenciamento desses serviços, o Operador Logístico B utiliza Sistema de Gerenciamento de Armazém (ou Warehouse Management System WMS) e de Gerenciamento de Transporte (ou Transportation Management System - TMS), com rastreamento e localização via web, além de Troca Eletrônica de Dados (ou Eletronic Data Interchange - EDI) com os seus clientes e extranet com as transportadoras e clientes para verificar a posição (status) de entrega dos produtos.

Com sede no interior de São Paulo, o Operador logístico B possui centros de distribuição dedicados, compartilhados ou no próprio cliente. A estrutura de distribuição adotada para os embarcadores que fazem parte deste estudo de caso, contempla: CD no próprio cliente e transportadora exclusiva para a distribuição urbana na RMSP (Transportador B).

Já o Transportador B é uma empresa de capital nacional, com sede no estado de Goiás, possui 6 filiais, sendo três no Estado de São Paulo. Oferece serviços de transporte rodoviário de carga de diversos tipos, principalmente, para os setores automobilístico, farmacêutico, químico, consumo e varejo. A parceria do Transportador B com o Operador logístico B tem mais de dois anos, representando mais de $40 \%$ do faturamento do transportador em 2013. Os serviços prestados se referem ao transporte como: coleta, transferência, separação, roteirização, distribuição, rastreamento e localização da carga, e logística reversa. O Transportador B é ainda o prestador de serviços de transporte exclusivo do Operador Logístico B nas operações de distribuição de carga fracionada na RMSP.

O site do Transportador B, localizado na RMSP, possui instalações estruturadas para realizar operações de cross-docking, recebendo carretas provenientes dos CDs do Operador logístico B, localizados no interior de São Paulo, entre $17 \mathrm{~h}$ e $2 \mathrm{~h}$ 
da manhã. A distribuição inicia a partir das $7 \mathrm{~h}$ da manhã até $12 \mathrm{~h}$, com o objetivo de garantir o atendimento das entregas dentro do lead time de $24 \mathrm{~h}, \mathrm{D}+1$, ou conforme agendamento de entrega no caso de CDs de grandes redes varejistas e distribuidores.

O Transportador B contrata e administra, em média, o serviço de 50 agregados, podendo chegar a 80 agregados, por meio de contratos individuais com apenas um veículo de entrega. Por sua vez, o motorista recebe treinamento nos procedimentos internos, sendo também o responsável por contratar, quando necessário, um ajudante para auxiliar nas entregas. Vale ressaltar que o Transportador B também se responsabiliza pelo treinamento desses ajudantes.

Além da frota contratada, o Operador logístico B possui também frota própria para entrega de grandes volumes em CDs dos clientes. Neste caso, o carregamento do veículo ocorre à noite e, eventualmente, o veículo retorna ao $C D$ e faz mais uma viagem no período da tarde.

Em média, são realizadas 120 entregas diárias na operação dedicada ao Operador logístico $\mathrm{B}$, na maioria com 4 a 5 entregas por veículo. Este número de entregas pode alcançar até 15 entregas diárias por veículo, exceto no caso de CDs e grandes lojas do varejo, quando a entrega é feita com carro dedicado. A frota terceirizada é composta por veículos de diversas capacidades, na sua maioria vans e caminhonetes com baús com capacidade de até $1.500 \mathrm{~kg}$, com volumes expedidos na faixa de 70 a 180 volumes/veículo.

\subsection{CASO B - APRESENTAÇÃO DOS EMBARCADORES E SEUS CLIENTES VAREJISTAS}

Os Embarcadores B1 e B2 representam juntos cerca de $50 \%$ das entregas diárias, ou seja, em média de 15 a 20 veículos de entrega por dia.

O Embarcador B1 é uma empresa multinacional fabricante de vestuários, calçados e equipamentos de uso individual e coletivo para a prática de esportes. No Brasil, $90 \%$ dos produtos comercializados são importados de diversos países. Após 
nacionalização, os produtos são transferidos para o CD do Operador logístico B localizado no interior de São Paulo, por uma transportadora contratada pelo Embarcador B1.

Os produtos produzidos no Brasil também são recebidos e armazenados no CD do Operador logístico B, que é o responsável pela distribuição nacional de $100 \%$ dos produtos comercializados pelo Embarcador B1, sendo $75 \%$ da distribuição por transporte de carga fracionada. Em 2013, o estado de São Paulo representou 50\% do faturamento total da Empresa B1, sendo a RMSP responsável por aproximadamente $60 \%$ desse faturamento.

O Embarcador B2 é uma empresa multinacional fabricante de produtos químicos e materiais para revelação de filmes. Atua no segmento varejo e industrial. Desde 2008, vem consolidando a estrutura de distribuição através de distribuidores nacionais, reduzindo a base de clientes atendidos diretamente de 2300 para 800 , meta alcançada no primeiro ano do projeto. Atualmente, possui 400 clientes ativos, sendo $70 \%$ distribuidores, $15 \%$ grandes redes varejistas e $15 \%$ varejo em geral. $\mathrm{O}$ estado de São Paulo representa $70 \%$ do faturamento total da empresa e a RMSP responde por $50 \%$ deste valor, ou seja, $35 \%$ do faturamento nacional.

O contrato estabelecido entre o Embarcador B e o Operador logístico B possui prazos de entrega acordados por micro região para todo o país, sendo $48 \mathrm{~h}$ para RMSP ou conforme agendamento programado com as grandes redes varejistas e CDs dos distribuidores, que representa, aproximadamente, $20 \%$ das entregas.

O Operador logístico B possui procedimentos operacionais padronizados estabelecidos no sistema de gestão de armazenagem e distribuição, visando garantir o atendimento aos clientes dentro dos prazos, custos e padrões de qualidade estabelecidos, registrando e monitorando as ocorrências relacionadas às atividades críticas de armazenagem e distribuição, tais como: recebimento físico e fiscal, descarregamento, manuseio, armazenagem, localização no inventário, separação, identificação dos volumes com etiquetas coloridas por região e transportador, conferência e programação da coleta. Além disso, estabelece a sistemática de execução no tratamento de anomalias no recebimento, na coleta, devolução de mercadorias, logística reversa e gestão do inventário. 
O transporte de carga e distribuição é monitorado por meio de rádio e, no caso de anomalia no processo, como, por exemplo, tempo de entrega superior a 45 minutos, a transportadora comunica imediatamente o operador logístico que busca eliminar o risco de devolução ou retorno de carga junto ao cliente. Além disso, o rastreamento e localização da carga, fornecem informações on line sobre o desempenho da distribuição e segurança da carga. O desempenho da entrega é monitorado diariamente por meio de ferramenta web de gerenciamento do transporte (TMS), onde deve ser realizada a baixa do manifesto do transporte até o dia seguinte a data de entrega, no período da manhã, ou então o motivo do não atendimento.

Visando garantir a entrega na data e horário agendados, dentro do lead time de 24 horas, o Operador logístico B possui um fluxo de atendimento ao pedido com prazos definidos e alinhados com seus clientes e apresenta as seguintes regras:

Embarcador B1: o corte de pedido é feito às $14 \mathrm{~h}$ e $17 \mathrm{~h}$. A partir das $14 \mathrm{~h}$, começam as operações de expedição no $C D$ do Operador logístico $B$, disponibilizando o material para coleta. $O$ Transportador $B$ recebe a programação de entrega com as NFs via e-mail, e inicia a roteirização e planejamento da entrega. No CD do Transportador $\mathrm{B}$, os produtos são separados até às $22 \mathrm{~h}$ e a expedição ocorre a partir das 7 h00 no dia seguinte.

Embarcador B2: as cargas são feitas às 14h e 15h e o corte ocorre às 18h. A partir das $18 \mathrm{~h}$, começam as operações de expedição no CD do Operador logístico B, disponibilizando o material para coleta. O Transportador $B$ recebe a programação de entrega com as NFs via e-mail, e inicia a roteirização e planejamento da entrega. No $C D$ do Transportador $B$, os produtos são separados até às $22 \mathrm{~h}$ e a expedição ocorre a partir das 7 h00 no dia seguinte.

O Quadro 10 apresenta as características dos clientes dos Embarcadores B1 e B2 entrevistados no estudo de caso, respectivamente Clientes B1a; B1b e B2a; B2b.

Quadro 10 - Características dos Clientes - Estudo de caso B

\begin{tabular}{|c|c|c|}
\hline Embarcador & Cliente & Características \\
\hline Embarcador B1 & Cliente B1a & $\begin{array}{l}\text { - } 15 \text { lojas no Brasil, sendo } 10 \text { no estado de São } \\
\text { Paulo. } \\
\text { - CD com } 80 \text { funcionários. } \\
\text { - Recebe } 30 \text { a } 50 \text { veículos/dia de diversos } \\
\text { embarcadores. }\end{array}$ \\
\hline
\end{tabular}




\begin{tabular}{|c|c|c|}
\hline Embarcador & Cliente & Características \\
\hline & & $\begin{array}{l}\text { - Entregas são agendadas. } \\
\text { - Janela de entrega das } 9 \mathrm{~h} \text { às } 16 \mathrm{~h} \text {. } \\
\text { - Expede } 5 \text { veículos/dia com no máximo } 2 \\
\text { entregas/veículo. } \\
\text { - Possui local para carga e descarga. }\end{array}$ \\
\hline & Cliente B1b & $\begin{array}{l}\text { - Possui duas lojas na RMSP. } \\
\text { - As lojas comercializam apenas produtos da } \\
\text { Empresa B1. } \\
\text { - } 15 \text { funcionários em cada loja. } \\
\text { - Recebe diariamente em horário comercial. } \\
\text { - Recebe } 1 \text { veículo/dia com } 70 \text { volumes, no } \\
\text { máximo } 100 . \\
\text { - Não tem local para carga e descarga. }\end{array}$ \\
\hline \multirow[t]{2}{*}{ Embarcador B2 } & Cliente B2a & $\begin{array}{l}\text { - Possui uma loja na RMSP. } \\
\text { - Tem } 8 \text { funcionários. } \\
\text { - Recebe } 2 \text { veículos por semana, sendo } 1 \\
\text { veículo com entrega da Empresa B2. } \\
\text { - } 10 \text { volumes por entrega. } \\
\text { - Não tem local para carga e descarga. }\end{array}$ \\
\hline & Cliente B2b & $\begin{array}{l}\text { - } \text { CD com } 20 \text { funcionários. } \\
\text { - Recebe } 10 \text { veículos de entrega/dia de diversos } \\
\text { embarcadores. } \\
\text { - Recebe } 3 \text { entregas na semana da Empresa B2. } \\
\text { - Não tem agendamento de entrega. } \\
\text { - Janela de entrega das } 8 \mathrm{~h} \text { às } 18 \mathrm{~h} \text {. } \\
\text { - Expede } 2 \text { veículos/dia com no máximo } 3 \\
\text { - } \quad \text { entregas/veículo. } \\
\text { - Possui local para carga e descarga. }\end{array}$ \\
\hline
\end{tabular}

Os Clientes B1a e B2b são CDs de grandes redes de artigos esportivos responsáveis pelo abastecimento das lojas em todo o estado de São Paulo. Os dois CDs possuem local adequado para carga e descarga, janela de entrega, sendo que apenas o Cliente B1a trabalha com agendamento de horário para entrega de mercadorias.

Já os Clientes B1b e B2a são lojas do varejo, não possuem local para carga e descarga, recebem carga diariamente em horário comercial sem necessidade de agendamento.

Dada à relevância das duas empresas, Embarcadores B1 e B2, em termos de volume de entrega ao varejo na RMSP, e considerando a sua importância para o estudo da distribuição física de carga RMSP, as próximas seções se referem às 
operações logísticas dedicadas a essas empresas, especificamente às características operacionais dos prestadores de serviços logísticos, aos papéis dos agentes (embarcador, operador logístico, transportador e cliente) e à estrutura de distribuição.

\subsection{CASO B - PAPÉIS DOS AGENTES E A ESTRUTURA DE DISTRIBUIÇÃO}

De acordo com as informações coletadas por meio de entrevistas realizadas com os agentes participantes deste estudo e observações de campo, pôde-se obter a estrutura da distribuição de carga (Figura 18).

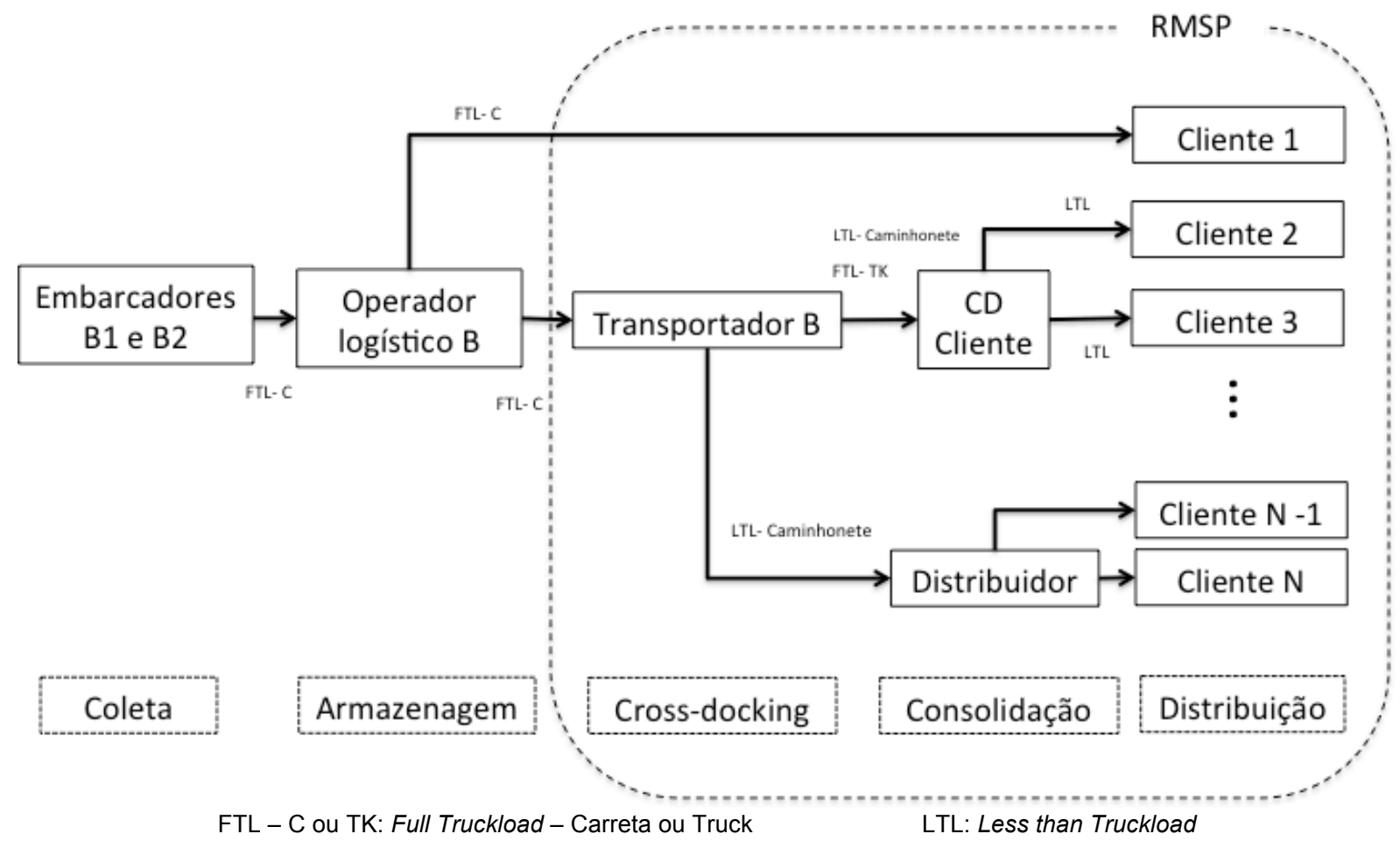

Figura 18 - Estrutura da distribuição de carga na RMSP-Operador logístico B

A Figura 18 mostra os agentes e o fluxo de carga. Os Embarcadores B1 e B2 são responsáveis pela entrega da carga no Operador $\mathrm{B}$, que está localizado no interior do estado de São Paulo, perto da RMSP (linha pontilhada). A transportadora que realiza a coleta é contratada pelos Embarcadores. Após a coleta, a carga é armazenada no CD do Operador logístico B, que é o prestador de serviços logísticos 
responsável pela gestão de armazenagem e transporte dos produtos para os clientes. O Transportador B, localizado dentro da RMSP, é contratado pelo Operador Logístico B para o transporte de carga na RMSP. As entregas aos Clientes são feitas diretamente nas lojas do varejo, ou via CDs de grandes clientes ou de distribuidores (apenas no caso do Cliente B2).

Conforme esquema apresentado na Figura 18, nota-se que os Embarcadores B1 e B2 distribuem seus produtos por meio de instalações logísticas de terceiros, Operador B, Centros de Distribuição e Distribuidor. A distribuição pode ser feita diretamente do Operador logístico A para os estabelecimentos do varejo, ou indiretamente via CD de grandes redes varejistas ou distribuidores (apenas Embarcador B2).

O transporte da carga até as instalações do Operador B é responsabilidade dos Embarcadores. A transportadora contratada realiza as operações de coleta no embarcador e remessa da carga até as instalações do Operador logístico B localizadas próximas à RMSP e nos sites de cada um dos que os embarcadores, otimizando o frete de longa distância ao utilizar veículos maiores (carretas) com carga completa. No entanto, o transporte realizado na movimentação da carga entre o CD do Operador logístico B e o CD do Transportador B, é contratado pelo operador logístico. Já o transporte e distribuição de carga na RMSP é realizado exclusivamente pelo Transportador B.

Como estratégia de distribuição, os Embarcadores B1 e B2 utilizam o Operador logístico B como uma instalação intermediária de armazenagem dos produtos que, por sua vez, utiliza as instalações do Transportador B visando maior agilidade no fluxo da mercadoria e eficiência no transporte por meio de consolidação de carga, dentro do conceito de cross-docking, realizando a roteirização da entregas dos produtos sem armazenagem adicional, salvo as entregas com data agendada. Nesses casos, a carga fica estocada no CD da Transportadora B até a data de entrega, conforme agendamento com o CD dos Clientes.

O Operador logístico B é o provedor de serviços logísticos central desta estrutura de distribuição, executando de forma coordenada as atividades de armazenagem e separação do produto em estoque, e providenciando a coleta e transporte conforme carteira de pedidos enviada pelo embarcador, garantindo maior agilidade no 
atendimento das necessidades do cliente, como janela de entrega e horário agendado para recebimento.

A contratação de transportadoras, negociação de frente e monitoramento da entrega são papéis também desempenhados pelo Operador logístico B. O transporte da carga pode ser feito diretamente do CD do Operador logístico B para os Clientes por meio de carga completa (FTL) em veículos dedicados, trucks ou carretas, para clientes de grande volume localizados na RMSP, sem passar pelo CD do Transportador B. No entanto, mais de 95\% do volume de entrega dos Embarcadores B1 e B2 na RMSP, são movimentados na operação de cross-docking realizada pelo Transportador B.

O Transportador B é o responsável pela distribuição de carga dos Embarcadores B1 e B2, sendo a distribuição da mercadoria realizada por meio de veículos menores nas entregas diretas aos clientes e no caso de distribuidores, possibilitando maior frequência de entrega e flexibilidade de horário, mas com baixa ocupação do veículo.

O transporte também pode ser realizado indiretamente por meio de remessa de carga completa em veículos dedicados com entregas agendadas, que representam menos de $10 \%$ das entregas programadas, para os centros de distribuição dos Clientes, que vão realizar a consolidação de carga de diversos embarcadores, a armazenagem por um curto período de tempo e a distribuição para o destinatário final.

Os CDs das grandes redes recebem produtos just in time, oferecendo agilidade no atendimento ao cliente. Realiza atividade de consolidação de carga de diversos embarcadores, a armazenagem por um curto período de tempo e a distribuição para o destinatário final.

O Distribuidor, além das atividades logísticas descritas para o $C D$, é o responsável pela comercialização e atendimento ao cliente, sem delimitação regional. Operacionalmente, viabiliza a comercialização de lotes menores e com agilidade de atendimento, diminuindo o lead time do pedido.

O Cliente B1a é um CD de uma grande rede de artigos esportivos, com maior poder de influência na cadeia dos que os demais clientes, no que se refere aos atributos 
janela de entrega, agendamento, requisitos específicos para o recebimento de mercadoria, comprometimento na entrega e carros dedicados. No caso dos clientes que não fazem parte de redes varejistas, Clientes B1b e B2a, os atributos de distribuição que podem vir a impactar o desempenho da entrega estão relacionados ao volume de entrega, ocupação de veículo, flexibilidade, comprometimento de entrega e local adequado para carga e descarga.

O Cliente B2b é um distribuidor de produtos do Cliente B2 que possui CD, no entanto, não exige agendamento. Para este cliente, o prazo de entrega, frequência de entregas e quantidade entregue, são importantes para atender com agilidade o destinatário final e para garantir o giro de estoque adequado ao negócio, por se tratar de produto cotado em dólares.

\subsection{CASO B - ATRIBUTOS DE DISTRIBUIÇÃO DE CARGA E INDICADORES DE DESEMPENHO LOGÍSTICO}

Para os Embarcadores B1 e B2, as operações realizadas pelo Operador logístico B são relacionadas ao gerenciamento e execução da armazenagem e transporte. Portanto, os atributos logísticos de distribuição de carga se referem às atividades internas ao CD (recebimento, armazenagem, processamento de pedidos $\mathrm{e}$ expedição) e ao transporte. Nesse sentido, os principais problemas enfrentados pelo Operador logístico B são: o não cumprimento dos horários de corte para recebimento da carteira de pedido e atraso na expedição de carga (coleta).

Com relação às atividades no $C D$ do Transportador $B$ destaca-se a chegada em atraso do material coletado no $C D$ do Operador B. Segundo o entrevistado, isso tem impactado os processos internos de conferência, separação e expedição, o não recebimento da programação de entregas e NFs com antecedência necessária para a roteirização e planejamento do embarque, demora na liberação do caminhão pela seguradora na chegada ao local de entrega, e alterações urgentes, postergações ou antecipações, no agendamento de entrega por parte do cliente. 
Todas as entregas são programadas e planejadas conforme roteirização baseada no início (cabeça) do CEP, considerando as restrições de circulação, rodízio e janelas de entrega dos clientes. A maioria das entregas nas lojas pode ser feita em horário comercial, ao passo que os CDs e os shoppings centers definem agendamentos ou janelas de entregas específicas com procedimentos de entregas definidos, tais como: necessidade de mais de um ajudante, estacionamento não permitido dentro das instalações do estabelecimento e cadastramento prévio dos ajudantes e motoristas.

O desempenho logístico da distribuição é monitorado através dos indicadores, descritos a seguir.

a) OTD (On time delivery): Cumprimento de lead time de entrega de mercadoria acordado em contrato.

b) Cumprimento de lead time de entrega de informação (nota máxima maior que $98 \%)$

c) Cumprimento da janela de coleta.

d) Devolução de canhotos conforme acordado em contrato.

e) Veículos em conformidade no check-list do administrador de seguro (nota máxima maior que 95\%).

f) Representatividade de reclamações procedentes, sob responsabilidade da transportadora em relação ao volume das notas fiscais transportadas.

g) Representatividade de sinistros sob responsabilidade da transportadora em relação ao valor de notas fiscais transportadas.

Como a distribuição na RMSP é feita exclusivamente pelo Transportador $B$, o nível de serviço do prestador de serviço de transporte pode fornecer uma leitura direta do desempenho da entrega para os Embarcadores B1 e B2.

No entanto, a métrica do indicador de desempenho do transporte, entrega na data conforme lead time definido em contrato (OTD), não considera a entrega não realizada por motivos comerciais na base de cálculo do indicador, como pedido cancelado, recusa total por divergência entre físico e fiscal, mercadoria não entregue por falta de pessoal para recebimento no cliente ou tempo de espera superior a $45 \mathrm{~min}$. 
O Transportador B, por sua vez, faz o monitoramento diário das entregas, controlando em uma planilha as NFs programadas e expedidas e fazendo o lançamento no sistema de transporte as NFs que foram entregues ou estão pendentes, conforme motivos cadastrados no sistema. O cálculo do indicador de desempenho sem nenhum abono por motivo comercial, demandaria um levantamento detalhado em todas as planilhas de controle diário do transportador e, então, a estratificação dos motivos de não atendimento geral.

Com o auxílio do Operador logístico B, formam identificados os problemas recorrentes e abonados no cálculo do indicador de desempenho logístico (OTD), para os Embarcadores B1 e B2, durante a distribuição de carga no estado de São Paulo. No entanto, informação da frequência dos eventos não pode ser considerada, pois em alguns casos o motivo do problema era genérico (ocorrência comercial) ou o campo não estava especificado. Esses problemas são apresentados a seguir:

- Aguardando agendamento.

- Data de entrega diferente do pedido.

- Destinatário encerrou atividades.

- Endereço de entrega errado ou não localizado.

- Entrega programada para o próximo dia útil.

- Estabelecimento fechado em horário comercial.

- Estrada ou acesso interditado.

- Falta de espaço físico no destinatário.

- Filas.

- Pedido cancelado ou em duplicidade

- Mercadoria em desacordo com o pedido

- Recusa, aguardando negociação

- Reentrega solicitada pelo destinatário

- Responsável pelo recebimento está ausente

- Tempo espera excedido no destinatário

Segundo os agentes entrevistados, Operador logístico B, Transportador B e os Embarcadores B1 e B2, o indicador de desempenho logístico para a RMSP (OTD) está dentro da meta acordada, $98 \%$, para os dois embarcadores e, portanto, não 
existe a demanda por uma rotina de controle e estratificação das causas do não atendimento por questões comerciais. Nessa linha, as ações corretivas são feitas diariamente, a cada evento, por meio de ações colaborativas para a solução dos problemas pontuais, garantindo o desempenho global.

Em 2012, segundo informado pelo Operador logístico B, foi feita uma ação conjunta com o Embarcador B1 com o objetivo de diminuir o índice de devoluções por recusa comercial e pedidos cancelados que estava superior à três por cento do total de entregas. Essa ação colaborativa permitiu que as devoluções ficassem dentro de um nível acordado entre as partes.

Os Clientes têm a mesma percepção quanto ao desempenho logístico apresentada pelos demais agentes, segundo dados levantados nas entrevistas individuais com os Clientes e no acompanhamento das entregas. No caso específico do Cliente B2a, existe uma expectativa em relação a redução do volume de entrega e aumento da frequência de entrega, pois o modelo de negócio desse cliente demanda um alto giro de estoque com redução de capital empregado, além de possuir espaço reduzido para estoque de mercadoria.

Segundo o Operador logístico B e o Transportador B, os principais problemas na distribuição que impactam negativamente o desempenho do indicador de entrega (OTD) são: a) atributos logísticos: janela de entrega, tempo para descarga, local adequado para descarga, número de entregas, quantidade e tipo de veículos, falta de veículo nos períodos de picos de venda (datas festivas); b) atributos de colaboração: assimetria de informação, falta de comunicação direta com o destinatário, falta de flexibilidade nas janelas de entrega (principalmente em shoppings, grandes redes e magazines), não cumprimento dos agendamentos (priorizando cargas urgentes ou perecíveis); c) atributos regulatórios: restrição e circulação e falta de infraestrutura nas vias públicas para estacionar; e d) atributos de risco: congestionamento e falta de segurança em áreas de risco.

Assim como os prestadores de serviços logísticos, os Embarcadores B1 e B2 e os Clientes B1 e B2 destacam o congestionamento, falta de segurança em zonas de risco e restrição de circulação de veículos como problemas que podem comprometer a entrega, causando atrasos ou não cumprimento da janela de entrega ou agendamento. 
Além desses atributos regulatórios e de risco, segundo o Operador logístico B e o Transportador B, os atrasos também são ocasionados pela demora na entrega, por conta do tempo gasto procurando vaga para estacionar o veículo, devido a falta de local adequado para estacionamento, carga e descarga, e o tempo gasto com a conferência da carga no cliente. Segundo esses entrevistados, isso tem comprometido a execução do planejamento da entrega e do roteiro estabelecido.

O Operador logístico B e o Transportador B destacaram a falta de comprometimento e confiabilidade, que são atributos de colaboração, como os principais motivos da demora na conferência, que é feita por meio da abertura de $100 \%$ das caixas e contagem unitária. Este fato foi constatado na maioria das entregas acompanhadas. Em alguns casos, a entrega chegou a demorar 1 hora, desde a chegada, passando pela conferência até a saída do estabelecimento. Observou-se que a conferência é responsável por cerca de $80 \%$ do tempo de entrega.

Segundo um determinado cliente, este procedimento de abertura das caixas e contagem de $100 \%$ da mercadoria é norma interna da loja para evitar o processo de abertura de reclamação posterior à entrega no site do Embarcador B1, por motivo de divergência entre a quantidade entregue e a NF ou por problemas de qualidade. Como a solução para esses casos, que envolve o ressarcimento ou retirada do material com defeito, pode demorar mais de uma semana, o cliente prefere verificar se existe alguma anomalia no momento da entrega e efetuar a devolução de $100 \%$ da carga.

Ainda sobre a duração da entrega, aconteceu um caso durante o trabalho de campo, que retrata a falta de estrutura adequada para o recebimento de mercadoria e assimetria de informação. Trata-se de uma entrega em uma loja de shopping localizado em local de risco, sem local para carga e descarga. Logo, o veículo ficou estacionado em uma vaga comum na rua, próxima à entrada do shopping que é utilizada pelos funcionários do shopping e também para carga e descarga. A entrada, além de estreita, tem uma das folhas da porta mantida fechada por questões de segurança, permitindo a passagem de uma pessoa por vez.

Além disso, a entrada tem uma escada com 6 degraus e não possui rampa para utilização de carrinho, que foi carregado escada acima pelos motorista e ajudante. 
Por conta disso, as caixas foram retiradas uma a uma do caminhão e levadas até o carrinho dentro do shopping.

Como trata-se de uma área de risco, o ajudante ou o motorista teve que permanecer ao lado do caminhão, vigiando a carga, enquanto o outro carregava as caixas até o carrinho. Segundo informado pelo motorista, normalmente, as entregas para esse cliente são feitas com dois ajudantes.

Além das deficiências estruturais e falta de segurança, o segurança do shopping center comunicou ao motorista que a janela de entrega havia sido alterada, terminando às $11 \mathrm{~h}$ e não mais ao meio dia. Após $11 \mathrm{~h}$, não seria permitida a circulação de carrinho dentro do shopping. A entrega durou ao todo $2 \mathrm{~h} 30 \mathrm{~min}$, e contou também com a ajuda do cliente, designando um funcionário para separar e contar os 281 volumes enquanto as caixas eram transportadas em 4 viagens até o terceiro andar do shopping, utilizando dois carrinhos por viagem, e enfrentando filas nos elevadores.

Ainda sobre os atributos de colaboração, o Transportador B destacou a falta de flexibilidade para entrega em horários e em locais com características especiais, principalmente nos shoppings e CDs das grandes redes e magazines. Segundo o entrevistado, a flexibilização das janelas de entrega, principalmente em áreas de risco, poderia contribuir para o melhor desempenho das entregas "todas as entregas são feitas com motorista e ajudante. No entanto, a falta de locais específicos para carga e descarga comprometem a segurança da carga e, em alguns casos, tivemos que propor mudanças nos horários ao longo do mês, principalmente na segunda quinzena, para evitar roubos".

O entrevistado relatou ainda que a restrição de circulação de caminhões também contribui para a falta de segurança, uma vez que o volume entregue por uma carreta de 18,60m é distribuído em 15 veículos totalizando 75 metros. O aumento do número de veículo na rua pode vir a comprometer o trânsito ocasionando congestionamento, risco de acidentes e roubo de carga.

Ainda sobre os atributos regulatórios, segundo o Operador logístico B e Transportador $\mathrm{B}$, a política de restrição de circulação de caminhão no centro 
expandido já foi endereçada com a frota contratada composta principalmente por veículos menores (caminhonetes e vans).

Os atributos ambientais, como tipo de combustível e normas para controle de emissões, não foram destacados pelos entrevistados no estudo de caso provavelmente por não serem prioridade frente aos demais problemas enfrentados diariamente na distribuição de carga na RMSP.

Segundo os entrevistados, os demais atributos de risco, como greves, manifestações e enchentes, constituem também fatores que interferem no desempenho logístico, embora não tão relevantes quando comparados aos já apresentados. Esta revelação se deve à proximidade e colaboração entre os Operador logístico B e os Embarcadores B1 e B2 quanto à flexibilização de horários de entrega junto aos clientes no caso desses eventos.

O Quadro 11 sintetiza os atributos de distribuição levantados no estudo de caso B, segundo a percepção das empresas.

Quadro 11 - Síntese dos atributos de distribuição - Estudo de caso B

\begin{tabular}{|c|c|c|c|c|}
\hline Atributos & Embarcador & $\begin{array}{l}\text { Operador } \\
\text { Logístico }\end{array}$ & Transportador & Cliente \\
\hline \multicolumn{5}{|l|}{ 1. Atributo logístico } \\
\hline frequência de entrega & & & & $x$ \\
\hline janela de entrega & $\mathrm{x}$ & $x$ & $\mathrm{x}$ & $\mathrm{x}$ \\
\hline local adequado para carga e descarga & & $x$ & $x$ & \\
\hline \multicolumn{5}{|l|}{ filas } \\
\hline prazo de entrega & & & & $x$ \\
\hline tempo de carga e descarga & & $\mathrm{x}$ & $\mathrm{x}$ & \\
\hline quantidade entregue ou consumo sazonal & & $x$ & $\mathrm{x}$ & \\
\hline quantidade e tipo de veículos & & $\mathrm{x}$ & $\mathrm{x}$ & \\
\hline número de entregas & & $\mathrm{x}$ & $\mathrm{x}$ & \\
\hline ocupação do veículo & & $x$ & & \\
\hline custo do transporte & & $x$ & & \\
\hline \multicolumn{5}{|l|}{ distância percorrida } \\
\hline \multicolumn{5}{|l|}{ 2. Atributos de colaboração } \\
\hline compartilhamento de informações & & $\mathrm{x}$ & $\mathrm{x}$ & \\
\hline compartilhamento de ganhos e custos & & $x$ & & \\
\hline comprometimento & & $x$ & $x$ & $x$ \\
\hline confiabilidade & & $x$ & $x$ & \\
\hline
\end{tabular}




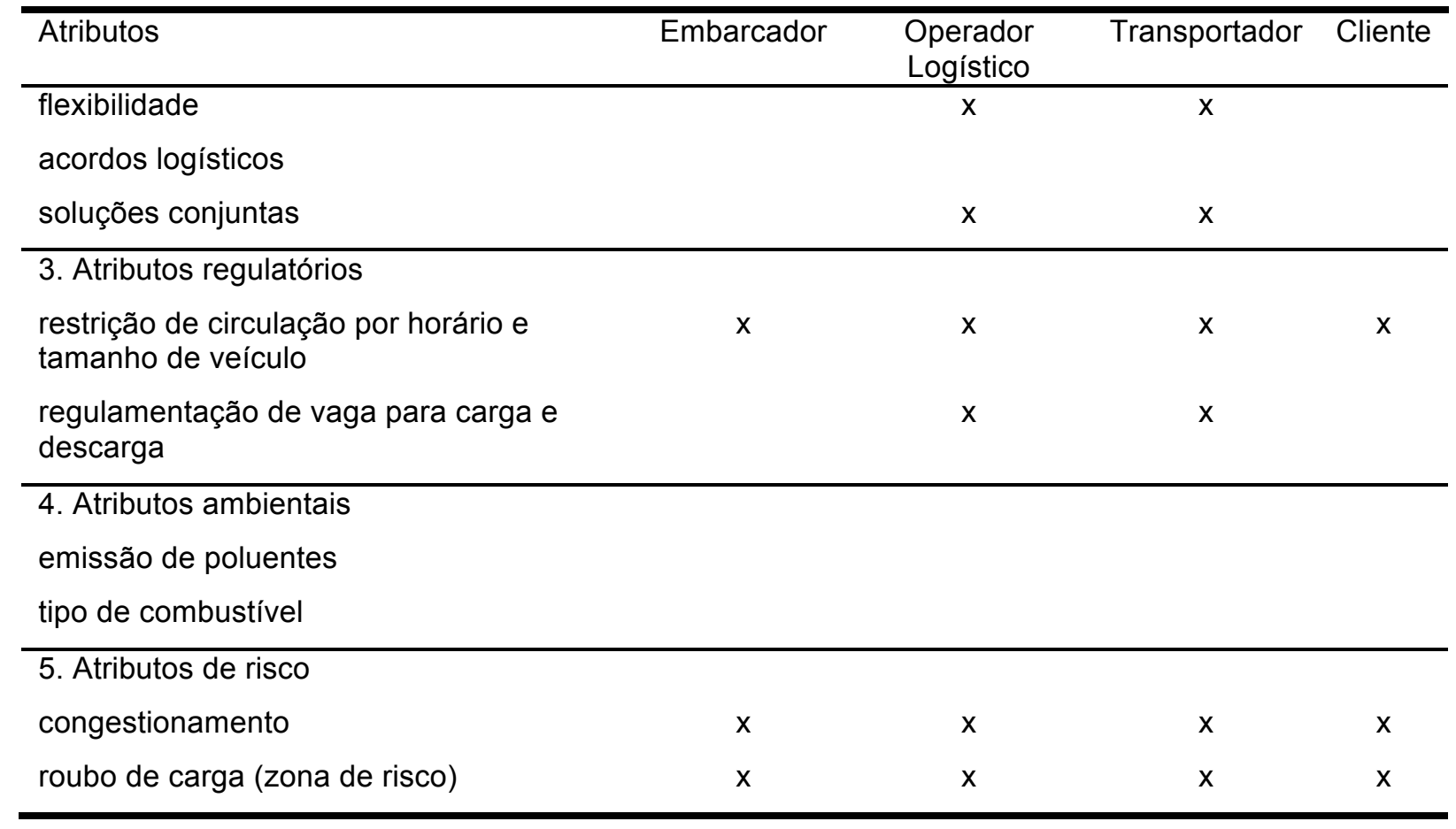

Conforme apresentado no Quadro 11, o Operador logístico B e o Transportador B compartilham a mesma percepção em relação à maioria do atributos de distribuição pois ambos possuem abordagem sistêmica e voltada a eficiência do global da distribuição. No entanto, o custo do transporte e ocupação do veículo são atributos logísticos destacados apenas pelo Operador logístico $\mathrm{B}$, talvez por ser o agente central da cadeia de distribuição e responsável pela busca de ações de redução de custos logísticos e compartilhamento desses ganhos com os demais agentes.

Dada a proximidade e parceria entre os agentes prestadores de serviços logísticos nesse estudo, soluções conjuntas é um atributo de colaboração também relatado pelo Transportador B como fundamental para um melhor desempenho da distribuição.

Os atributos ambientais não foram citados como relevantes pelos entrevistados no estudo de caso B. Este fato pode ser decorrente da não exigência de práticas sustentáveis pelos Embarcadores B1 e B2 e Clientes C1 e C2, ou por não se destacarem frente aos demais atributos da distribuição de carga na RMSP.

Os atributos de risco como congestionamento e roubo de carga em zonas de risco são unanimidade entre os agentes. Esses problemas podem comprometer 0 atendimento do prazo de entrega, que é um dos atributos mais relevantes segundo 
os Clientes, que demandam cada vez mais agilidade da cadeia de distribuição por conta dos baixos níveis de estoque e pequenos volumes de entrega.

Apesar das empresas adotarem procedimentos padronizados para segurança do transporte de carga, existe uma atenção constante por parte do Operador logístico B e do Transportador B que definem ações estruturadas para minimizar o roubo de carga, como rotas alternativas em zonas de risco, utilização de dois ajudantes e motorista com dedicação exclusiva em determinadas áreas da cidade.

\subsection{ANÁLISE INTERCASOS}

A análise intercasos está dividida em duas partes. A primeira parte descreve os papéis dos agentes do canal de distribuição ao varejo, destacando o fato de que as empresas que compõem cada caso apresentam certas semelhanças e diferenças no tocante à distribuição de mercadorias na RMSP. A segunda parte se refere aos atributos de distribuição de carga e aos indicadores de desempenho logístico, sob o ponto de vista dos principais agentes: Embarcador, Operador logístico, Transportador e Cliente.

O Quadro 12 sintetiza os papéis desempenhados pelos agentes, identificados durante os estudos de caso, e seu alinhamento com as definições encontradas na literatura.

Quadro 12 - Principais papéis desempenhados pelos agentes na distribuição de carga na RMSP

\begin{tabular}{|c|c|c|c|}
\hline $\begin{array}{l}\text { Agente } \\
\text { Ref bibliográfica }\end{array}$ & Papel & $\begin{array}{l}\text { Estudo de } \\
\text { caso A }\end{array}$ & $\begin{array}{l}\text { Estudo de } \\
\text { caso B }\end{array}$ \\
\hline Embarcador & Define o canal de distribuição ao varejo & $x$ & $x$ \\
\hline \multirow[t]{4}{*}{$\begin{array}{l}\text { Blanco e Fransoo (2013); } \\
\text { Novaes (2004) }\end{array}$} & $\begin{array}{l}\text { Estabelece os protocolos de atendimento ao } \\
\text { cliente }\end{array}$ & $x$ & $x$ \\
\hline & $\begin{array}{l}\text { Gestão e manutenção da margens de vendas } \\
\text { dos seus produtos }\end{array}$ & $x$ & $x$ \\
\hline & Gestão da interface com o Cliente & $x$ & $x$ \\
\hline & Envio da carteira de pedido para o PSL. & $\mathrm{x}$ & $x$ \\
\hline
\end{tabular}




\begin{tabular}{|c|c|c|c|}
\hline $\begin{array}{l}\text { Agente } \\
\text { Ref bibliográfica }\end{array}$ & Papel & $\begin{array}{l}\text { Estudo de } \\
\text { caso A }\end{array}$ & $\begin{array}{l}\text { Estudo de } \\
\text { caso B }\end{array}$ \\
\hline \multirow[t]{7}{*}{$\begin{array}{l}\text { Operador logístico } \\
\text { Marrasco (2007) }\end{array}$} & $\begin{array}{l}\text { Gerenciamento das atividades logísticas: } \\
\text { armazenagem estoque e transporte. }\end{array}$ & $x$ & $x$ \\
\hline & $\begin{array}{l}\text { Gestão da interface entre embarcador e } \\
\text { transportador. }\end{array}$ & $x$ & $x$ \\
\hline & $\begin{array}{l}\text { Manuseio de documentação, monitoramento } \\
\text { rastreamento de informações. }\end{array}$ & $x$ & $x$ \\
\hline & $\begin{array}{l}\text { Agendamento de coleta (logística reversa) e } \\
\text { entrega. }\end{array}$ & $x$ & $x$ \\
\hline & $\begin{array}{l}\text { Podem atuar como terminais de consolidação, } \\
\text { desconsolidação, centro de fracionamento de } \\
\text { carga e picking. }\end{array}$ & $x$ & $x$ \\
\hline & Instalações próximas da área de distribuição & & $x$ \\
\hline & Instalações dentro da área de distribuição & $x$ & \\
\hline \multirow[t]{4}{*}{$\begin{array}{l}\text { Transportador } \\
\text { Stefanssonn (2006) }\end{array}$} & $\begin{array}{l}\text { Gerenciamento e execução da movimentação } \\
\text { da carga }\end{array}$ & & $x$ \\
\hline & Execução da movimentação da carga & $x$ & \\
\hline & $\begin{array}{l}\text { Podem vir a atuar como terminal de } \\
\text { crossdocking, conforme estrutura disponível. }\end{array}$ & & $x$ \\
\hline & $\begin{array}{l}\text { São proprietários em grande parte dos ativos, } \\
\text { veículos e equipamentos, podendo gerenciar } \\
\text { frotas terceirizadas }\end{array}$ & $x$ & $x$ \\
\hline \multirow[t]{2}{*}{$\begin{array}{l}\text { Cliente } \\
\text { Blanco e Fransoo (2013) }\end{array}$} & $\begin{array}{l}\text { Envia informações de demandas } \\
\text { eletronicamente ao fabricante ou durante visitas } \\
\text { comercial ao estabelecimento. }\end{array}$ & $x$ & $x$ \\
\hline & Defini as características e padrões de entrega. & $x$ & $x$ \\
\hline
\end{tabular}

O Quadro 12 mostra os principais papéis desempenhados pelos Embarcadores, Operadores Logísticos, Transportadores e Clientes que atuam na distribuição urbana de carga encontrados na literatura e identificados ao longo dos dois estudos de caso conduzidos neste trabalho. Percebe-se que os agentes que participaram deste estudo desempenham praticamente os mesmos papéis, apesar da diferença em termos de porte empresarial e tamanho das operações.

Considerando o fluxo da carga e estrutura de distribuição, pode-se destacar a presença de pelo menos um agente prestador de serviços logísticos que possui instalações físicas dentro da RMSP: Operador logístico A e Transportador B. Além 
disso, o Transportador B possui estrutura física para atuar como terminal de crossdocking.

Logo, nos dois casos, pode-se identificar alguns atributos de distribuição de carga que essa estrutura de distribuição proporciona em termos de resposta às demandas do cliente final e agilidade na entrega, como: prazo de entrega do pedido, tempo de entrega da mercadoria, frequência de entrega, flexibilidade e comprometimento com a entrega.

Nesse sentido, o Quadro 13 apresenta a síntese dos atributos mais citados na revisão da literatura, os atributos levantados nos estudos de casos e os atributos mais críticos sob o ponto de vista dos entrevistados. Segundo levantamentos e observações feitas durante o trabalho de campo, esses atributos podem vir a impactar o desempenho logístico da distribuição urbana de carga.

Quadro 13 - Síntese dos atributos: Revisão da literatura e Estudos de caso

\begin{tabular}{|c|c|c|}
\hline $\begin{array}{l}\text { Revisão da literatura } \\
\text { (mais citados) }\end{array}$ & Estudo de caso A & $\begin{array}{c}\text { Estudo de caso } \\
\text { B }\end{array}$ \\
\hline \multicolumn{3}{|l|}{ 1. Atributo logístico } \\
\hline frequência de entrega & & $x$ \\
\hline janela de entrega & $x$ & $x$ \\
\hline local adequado para carga e descarga & $x$ & $x$ \\
\hline \multicolumn{3}{|l|}{ filas } \\
\hline prazo de entrega* & $x$ & $x$ \\
\hline tempo de carga e descarga & $x$ & $x$ \\
\hline quantidade entregue ou consumo sazonal & $x$ & $x$ \\
\hline quantidade e tipo de veículos & & $x$ \\
\hline número de entregas & $x$ & $x$ \\
\hline ocupação do veículo & $x$ & $x$ \\
\hline custo do transporte & $x$ & $x$ \\
\hline \multicolumn{3}{|l|}{ distância percorrida } \\
\hline \multicolumn{3}{|l|}{ 2. Atributos de colaboração } \\
\hline compartilhamento de informações & $x$ & $x$ \\
\hline compartilhamento de ganhos e custos & $x$ & \\
\hline comprometimento & $x$ & $x$ \\
\hline confiabilidade & $x$ & $x$ \\
\hline flexibilidade & $x$ & $x$ \\
\hline \multicolumn{3}{|l|}{ acordos logísticos } \\
\hline soluções conjuntas & $x$ & $x$ \\
\hline
\end{tabular}




\begin{tabular}{lcc}
\hline $\begin{array}{l}\text { Revisão da literatura } \\
\text { (mais citados) }\end{array}$ & $\begin{array}{c}\text { Estudo de } \\
\text { caso A }\end{array}$ & $\begin{array}{c}\text { Estudo de caso } \\
\text { B }\end{array}$ \\
\hline $\begin{array}{l}\text { 3. Atributos regulatórios } \\
\text { restrição de circulação por horário e } \\
\text { tamanho de veículo } \\
\text { regulamentação de vaga para carga e } \\
\text { descarga }\end{array}$ & $\mathrm{x}$ & $\mathrm{x}$ \\
\hline $\begin{array}{l}\text { 4. Atributos ambientais } \\
\text { emissão de poluentes }\end{array}$ & $\mathrm{x}$ \\
$\begin{array}{l}\text { tipo de combustível } \\
\text { 5. Atributos de risco } \\
\text { congestionamento }\end{array}$ & $\mathrm{x}$ & \\
roubo de carga (zona de risco) & $\mathrm{x}$ & $\mathrm{x}$ \\
\hline
\end{tabular}

Conforme o Quadro 13, os atributos mais críticos, segundo os estudos de caso, também foram encontrados na revisão da literatura realizada. Além disso, percebese praticamente uma unanimidade entre os principais problemas enfrentados na distribuição urbana de carga na RMSP encontrados nos dois estudos de casos. No entanto, pode-se identificar dois atributos que foram considerados relevantes apenas no estudo de caso B: frequência de entrega e quantidade de veículos. Além da demanda por agilidade na entrega, o aumento de frequência de reposição de estoques e, consequentemente, do número de veículos necessários para a entrega estão relacionados com a redução ou eliminação de estoques decorrentes de uma política de abastecimento "Just in Time" (JIT).

A Figura 19 propõe um esquema que relaciona a cadeia de suprimentos, indicadores de desempenho individuais, indicadores da cadeia de suprimentos e os atributos de distribuição urbana de carga. 


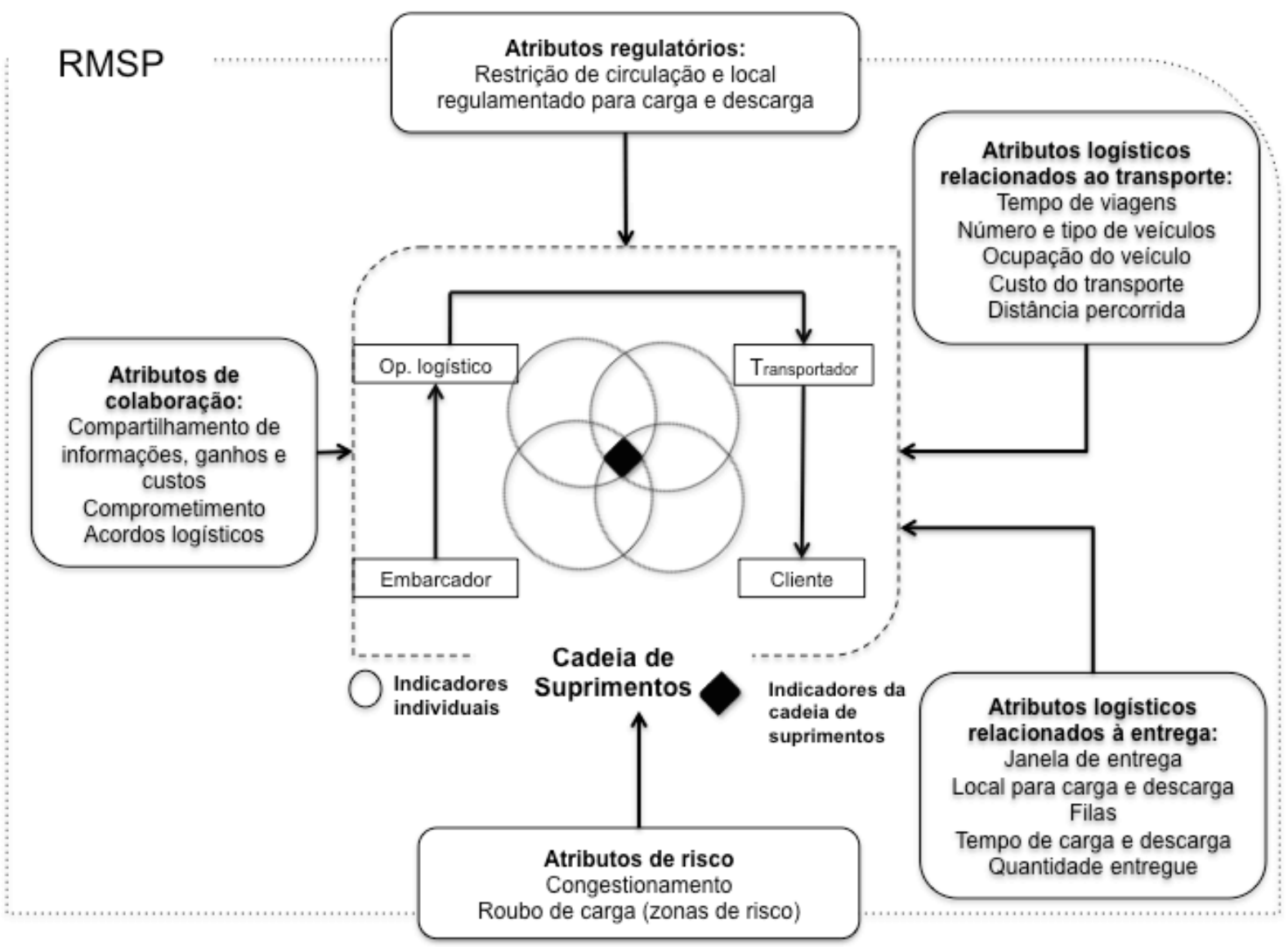

Figura 19 - Esquema que relaciona a cadeia de suprimentos, indicadores e atributos

Conforme esquema apresentado na Figura 19, as empresas atuam na cadeia de suprimentos com base nos papéis que desempenham na distribuição de carga e das atividades logísticas que executam (BALLOU, 2006).

Além disso, a Figura 19 mostra que as empresas possuem metas e indicadores individuais para medir o desempenho da distribuição que se relacionam com o desempenho logístico global da cadeia de suprimentos, tais como: prazo de entrega, tempo do ciclo do pedido e entregas no prazo (PIRES, 2011).

Resgatando as principais análises e discussões feitas ao longo dos estudos de caso, podemos sugerir algumas possíveis relações entre os atributos de distribuição e o desempenho logístico.

A dificuldade para estacionar no cliente ou nas vias públicas (atributos logísticos) foi outro grave problema apontado pelos entrevistados e identificado durante os acompanhamentos de entrega, pois aumenta o tempo gasto com as atividades de carga e descarga, podendo comprometer o percentual desejado de entregas no 
prazo e completas. Esse problema pode ser consequência de atributos regulatórios como falta de infraestrutura das vias e de local regulamentado para carga e descarga perto dos centros consumidores, e a sua solução depende do interesse das autoridades locais na priorização de medidas integradas para o transporte de carga na cidade.

Atributos logísticos como demora na conferência da carga ou até mesmo devolução da carga podem estar relacionados ao grau de colaboração entre dois ou mais agentes (Embarcador, Operador Logístico, Transportador e Cliente), tais como, compartilhamento de informação, flexibilidade e confiança, podendo vir a comprometer o desempenho das entregas programadas.

Nessa linha, dois ou mais agentes envolvidos podem estabelecer atributos de colaboração, como acordos logísticos que visam o comprometimento e agilidade no transporte e entrega, evitando filas, estabelecendo janelas de entrega flexíveis, tempo e local adequados para carga e descarga e quantidades de entregas mínimas, que são atributos logísticos que impactam diretamente a distribuição de carga na RMSP.

Verificou-se que os atributos regulatórios podem influenciar ou alterar a estratégia adotada na distribuição de carga pelos agentes envolvidos (Embarcador, Operador logístico, Transportador e Cliente) como, por exemplo, a utilização de veículos de carga menores sem restrição de circulação na cidade ou a necessidade de ajudante para agilizar a entrega em locais com falta de segurança e/ou sem vaga regulamentada para carga e descarga próxima ao cliente.

Da mesma forma, os atributos de risco também podem impactar negativamente o desempenho logístico devido ao elevado tempo em trânsito por conta dos congestionamentos recorrentes e do tempo despedido na procura de vaga para carga e descarga em local seguro.

Por outro lado, pode-se sugerir que o grau de colaboração entre dois ou mais agentes pode contribuir para a definição de ações colaborativas que minimizem a influência dos atributos regulatórios citados anteriormente e dos seguintes atributos de risco: congestionamentos, roubo de carga, greves e manifestações, o desempenho logístico da distribuição urbana de carga. 
Logo, por meio dos estudos de caso e da revisão da literatura, foi possível compreender os papéis dos agentes participantes da distribuição de carga, Embarcador, Operador Logístico, Transportador e Cliente (Quadro 15), assim como os atributos de distribuição urbana de carga que podem impactar o desempenho logístico da distribuição de carga na RMSP (Quadros 16 e Figura 19). Na sequência, serão apresentadas a análise do levantamento de dados da pesquisa e a discussão dos resultados para a identificação da relevância dos atributos de distribuição de carga na RMSP. 


\section{RESULTADOS: LEVANTAMENTO DE DADOS COM OPERADORES LOGÍSTICOS E TRANSPORTADORES (SURVEY)}

Este tópico tem por objetivo apresentar os resultados referentes ao levantamento de dados obtidos por meio da aplicação de questionário junto aos prestadores de serviços, Operador logístico e Transportador, visando identificar a relevância dos atributos de distribuição urbana de carga na RMSP.

O levantamento de dados foi realizado nessas empresas, Operador logístico e Transportador, porque elas são os principais agentes responsáveis pela logística de distribuição. Assim, as análises dos atributos de carga urbana e os indicadores de desempenho logístico fazem mais sentido serem analisados pela percepção dessas empresas fornecedoras de serviço. Por outro lado, a percepção de quem contrata o serviço, embora seja interessante, não faz parte deste levantamento.

Esta seção está subdividida em três partes. A primeira parte apresenta uma descrição das empresas entrevistadas. A segunda parte descreve sobre a percepção dessas empresas quanto aos atributos de distribuição de carga e a terceira parte sobre os indicadores de desempenho logístico.

\subsection{PERFIL DOS RESPONDENTES E ENTREGAS NA RMSP.}

Segundo a Tabela 6, a amostra é composta por executivos que ocupam posições gerenciais ou de direção nas empresas, ou seja, 83,33\% dos representante do operador logístico e 78,95\% dos representantes do transportador, com tempo médio no cargo de 9 anos (Operador logístico) e 14 anos (Transportador). Já os setores de atuação revelam uma variabilidade dos dados. 
Tabela 6 - Perfil dos respondentes

\begin{tabular}{|c|c|c|c|}
\hline Categorias & $\begin{array}{l}\text { Unidade de } \\
\text { Medida }\end{array}$ & $\begin{array}{l}\text { Operador } \\
\text { logístico }\end{array}$ & Transportador \\
\hline Cargo & $\%$ & & \\
\hline Diretor ou cargos acima & & 25,00 & 42,11 \\
\hline Gerente Sênior & & 58,33 & 36,84 \\
\hline Gerente & & 12,50 & 12,63 \\
\hline Outros cargos & & 4,17 & 8,42 \\
\hline $\begin{array}{l}\text { Tempo de experiência no } \\
\text { cargo }\end{array}$ & $\begin{array}{l}\text { anos } \\
\text { (média) }\end{array}$ & 9,00 & 14,00 \\
\hline $\begin{array}{l}\text { Setor de atuação da } \\
\text { empresa }\end{array}$ & $\%$ & & \\
\hline Alimentos e bebidas & & 10,98 & 14,13 \\
\hline Automotivo e autopeças & & 17,07 & 15,55 \\
\hline Vestuário e acessórios & & 9,76 & 10,25 \\
\hline $\begin{array}{l}\text { Bazar e material de } \\
\text { escritório }\end{array}$ & & 3,66 & 8,13 \\
\hline Telecomunicação e energia & & 6,10 & 7,77 \\
\hline Higiene pessoal e limpeza & & 17,07 & 10,60 \\
\hline Construção & & 0,00 & 8,13 \\
\hline $\begin{array}{l}\text { Química, hospitalar e } \\
\text { farmacêutica }\end{array}$ & & 14,63 & 11,66 \\
\hline Embalagem & & 0,00 & 1,77 \\
\hline Outros setores & & 1,22 & 1,41 \\
\hline Capital da empresa & $\%$ & & \\
\hline Empresa local & & 50,00 & 97,89 \\
\hline Multinacional & & 50,00 & 2,11 \\
\hline Localização da Unidade & $\%$ & & \\
\hline Cidade de São Paulo & & 45,83 & 76,84 \\
\hline Estado de São Paulo & & 41,67 & 9,47 \\
\hline Outros Estados & & 12,50 & 13,68 \\
\hline Número de funcionários & $\%$ & & \\
\hline$<10$ & & 0,00 & 12,63 \\
\hline $10-49$ & & 4,17 & 31,58 \\
\hline $50-99$ & & 12,50 & 23,16 \\
\hline$>100$ & & 83,33 & 32,63 \\
\hline $\begin{array}{l}\text { Faturamento Bruto }(R \$) \text { em } \\
2013\end{array}$ & $\%$ & & \\
\hline$<240$ mil & & 0,00 & 16,84 \\
\hline entre 240 mil e 2,4 milhões & & 0,00 & 27,37 \\
\hline$>2,4$ milhões & & 100,00 & 55,79 \\
\hline
\end{tabular}

Verifica-se que as transportadoras são, na maioria, empresas de capital nacional localizadas na cidade ou no estado de São Paulo, enquanto os operadores logísticos apresenta metade das empresas de capital nacional e com localização predominantemente fora da RMSP. 
Quanto ao faturamento, a amostra representa operadores logísticos com faturamento bruto em 2013 superior a R\$ 2,4 milhões e com quadro de lotação superior a 100 funcionários. Por outro lado, quase metade dos transportadores faturou menos do que $\mathrm{R} \$ 2,4$ milhões no mesmo período e apresenta o quadro de lotação distribuído nas quatro faixas, com 12,63\% das empresas contratando menos de 10 funcionários. Isso revela que as transportadoras representam empresas de pequeno e médio porte segundo a classificação do BNDES.

A frequência de entrega na RMSP pode variar entre os prestadores de serviços logísticos. A Tabela 7 mostra a frequência e outras características que compõe, neste trabalho, o perfil das entregas por prestador de serviço logístico.

Tabela 7 - Perfil das entregas na RMSP

\begin{tabular}{ccc}
\hline Característica das entregas & Operador Logístico & Transportador \\
\hline Percentual de entregas na RMSP & $\%$ & $\%$ \\
$<=50 \%$ & 58,33 & 36,84 \\
$>50 \%$ & 41,67 & 63,16 \\
Número de pontos de vendas atendidos diariamente & & \\
$<=30$ & 29,17 & 51,06 \\
$>30$ & 70,83 & 48,94 \\
Número de veículos utilizados diariamente & & \\
$<=10$ & 33,33 & 48,42 \\
$>10$ & 66,67 & 51,58 \\
Percentual de entregas diretas à loja & & \\
$<=25 \%$ & & 36,84 \\
$>25 \%$ & 25,00 & 63,16 \\
Percentual de veículos de carga terceirizados & 75,00 & \\
$<=25 \%$ & & 42,11 \\
$>25 \%$ & 12,50 & 57,89 \\
\hline
\end{tabular}

Conforme a Tabela 7, o percentual de entregas na RMSP é maior do que $50 \%$ para menos da metade dos operadores logísticos, ao passo que $63,16 \%$ dos transportadores realizam mais de $50 \%$ das suas entregas na RMSP. No entanto, $70,83 \%$ dos operadores logísticos atendem mais de 30 pontos de venda por dia na RMSP, enquanto esse mesmo número de estabelecimentos é atendido por menos da metade dos transportadores, 48,94\%. Logo, o número de veículos utilizado diariamente também é maior para o operador logístico, 66,67\% dessas empresas utilizam mais de 10 veículos por dia na distribuição de carga na RMSP, enquanto $51,58 \%$ dos transportadores operam com essas quantidades de veículos. 
A mesma situação é percebida quando trata-se do volume de entregas diretas às lojas. O percentual de operadores logísticos que realizam mais de $25 \%$ de suas entregas diretamente ao ponto de venda no varejo é de $75 \%$, enquanto $63,16 \%$ dos transportadores apresentam essa mesma característica de entrega.

Em relação à terceirização de veículos de carga, $87,50 \%$ dos operadores logísticos contratam mais de $25 \%$ da frota de veículos utilizados na distribuição de carga na RMSP, sendo esse nível de terceirização da frota adotado por $57,89 \%$ dos transportadores.

Logo, com base nas características apresentadas, pode-se dizer que a amostra de prestadores de serviços logísticos, Operador logístico e Transportador, possui perfis de entrega distintos na RMSP, no entanto verifica-se a representatividade que a distribuição de carga na RMSP tem para esses dois agentes.

\subsection{APRESENTAÇÃO DOS ATRIBUTOS MAIS RELEVANTES NA DISTRIBUIÇÃO URBANA NA RMSP}

Este tópico tem por objetivo identificar a relevância dos atributos de distribuição urbana de carga na RMSP. Para tanto, são apresentadas análises estatísticas descritivas a partir dos dados, ou seja, dos problemas percebidos pelos prestadores de serviços logísticos, Operador logístico e Transportador.

Nesse sentido, são apresentados os atributos de distribuição urbana de carga e seus valores específicos para os prestadores de serviços logísticos, Operador logístico e Transportador. As Tabelas 8 e 9 correspondem às medidas descritivas para os atributos, suas medidas de posição, a média, a mediana ( $\mathrm{Md})$, o primeiro quartil (Q1) e o terceiro quartil (Q3), e de dispersão, o desvio padrão ( $\sigma)$. 
Tabela 8 - Medidas descritivas dos atributos de distribuição sob a ótica do Operador logístico

\begin{tabular}{|c|c|c|c|c|c|c|c|c|}
\hline Atributos & Relevância. & Média & $\sigma$ & Mín. & Q1 & Md & Q3 & Máx. \\
\hline Combustível alternativo & & 3,75 & 2,05 & 1 & 2 & 4 & 5 & 7 \\
\hline Compartilhamento de informação & & 4,63 & 1,56 & 2 & 3 & 5 & 6 & 7 \\
\hline Comprometimento no recebimento & & 5,21 & 1,44 & 1 & 5 & 5 & 6 & 7 \\
\hline Confiança & & 4,71 & 1,81 & 1 & 3 & 5 & 6 & 7 \\
\hline Congestionamento & 1 & 6,42 & 1,02 & 3 & 6 & 7 & 7 & 7 \\
\hline Consumo sazonal (última semana do mês) & 1 & 6,08 & 1,50 & 1 & 6 & 7 & 7 & 7 \\
\hline Emissão de $\mathrm{CO} 2$ & & 3,92 & 1,91 & 1 & 2,75 & 4 & 5,25 & 7 \\
\hline Emissão de poluentes & & 4,04 & 1,99 & 1 & 2,75 & 4 & 5,25 & 7 \\
\hline Enchentes & & 4,13 & 1,90 & 1 & 2,75 & 4 & 5,25 & 7 \\
\hline Entrega Noturna & & 5,21 & 1,79 & 1 & 4 & 6 & 7 & 7 \\
\hline Filas para carga e descarga & 1 & 5,83 & 1,37 & 1 & 5 & 6 & 7 & 7 \\
\hline Flexibilidade & 2 & 5,54 & 1,61 & 1 & 5 & 6 & 7 & 7 \\
\hline Greves e manifestações & & 4,08 & 1,84 & 1 & 2,75 & 4 & 5 & 7 \\
\hline Lei do motorista & & 4,29 & 1,99 & 1 & 3 & 5 & 5,25 & 7 \\
\hline Local para carga/descarga & 2 & 5,79 & 1,44 & 2 & 6 & 6 & 7 & 7 \\
\hline Local para estacionar o veículo de carga & 2 & 5,63 & 1,56 & 2 & 4,75 & 6 & 7 & 7 \\
\hline $\begin{array}{l}\text { Requisitos de entrega (condições do } \\
\text { veículo, equipamentos) }\end{array}$ & & 5,04 & 1,43 & 2 & 4 & 5 & 6 & 7 \\
\hline $\begin{array}{l}\text { Requisitos referentes ao atendimento } \\
\text { (ajudante, SAC...) }\end{array}$ & & 5,21 & 1,50 & 2 & 4 & 5 & 7 & 7 \\
\hline Rodízio de veículos & 1 & 5,83 & 1,61 & 1 & 5 & 6,5 & 7 & 7 \\
\hline Tamanho do veículo & & 4,83 & 1,69 & 1 & 4 & 5 & 6 & 7 \\
\hline Taxa de ocupação & & 4,58 & 1,69 & 2 & 3 & 5 & 6 & 7 \\
\hline Tecnologia & & 5,04 & 1,52 & 1 & 4 & 5 & 6 & 7 \\
\hline Treinamento de pessoal transporte & & 4,67 & 1,52 & 2 & 3,75 & 5 & 5,25 & 7 \\
\hline Vias de acesso & & 5,25 & 1,75 & 1 & 4,75 & 6 & 7 & 7 \\
\hline Roubo de carga (zona de risco) & 2 & 5,88 & 1,60 & 1 & 5 & 7 & 7 & 7 \\
\hline Restrição de circulação & 2 & 5,79 & 1,93 & 1 & 5,75 & 7 & 7 & 7 \\
\hline
\end{tabular}

Pela Tabela 8 , observa-se unanimidade entre os operadores logísticos quanto à percepção dos atributos: congestionamento, rodízio de veículos, filas para carga e descarga e consumo sazonal (última semana do mês) (destacados em tom de cinza claro). Para esses atributos, obteve-se média próxima ou maior que 6 e pelo menos $75 \%$ dos respondentes atribuindo nota 6 ou 7 a eles. Adicionalmente, destacam-se entre os principais problemas para essas empresas o local para carga e descarga, local para estacionar o veículo, roubo de mercadoria (zona de risco) e restrição de circulação (zona máxima de restrição de circulação de caminhões) (em destaque com tom de cinza escuro). 
Tabela 9 - Medidas descritivas dos atributos de distribuição sob a ótica do Transportador

\begin{tabular}{lcccccccc}
\hline Atributos & Relevância & Média & $\sigma$ & Mín. & Q1 & Md & Q3 & Máx. \\
\hline Combustível alternativo & & 4,40 & 1,84 & 1 & 3 & 4 & 6 & 7 \\
Compartilhamento de informação & & 5,02 & 1,72 & 1 & 4 & 5 & 6 & 7 \\
Comprometimento no recebimento & 2 & 5,58 & 1,69 & 1 & 5 & 6 & 7 & 7 \\
Confiabilidade & & 4,64 & 1,81 & 1 & 3 & 5 & 6 & 7 \\
Congestionamento & 1 & 6,48 & 1,24 & 1 & 7 & 7 & 7 & 7 \\
Consumo sazonal (última semana do & & & & & & & & \\
mês) & & 5,44 & 1,90 & 1 & 4 & 6 & 7 & 7 \\
Emissão de CO2 & & 4,31 & 1,87 & 1 & 3 & 4 & 6 & 7 \\
Emissão de poluentes & & 4,39 & 1,92 & 1 & 3 & 4 & 6 & 7 \\
Enchentes & & 4,80 & 1,87 & 1 & 4 & 5 & 7 & 7 \\
Entrega noturna & & 4,93 & 2,04 & 1 & 4 & 5 & 7 & 7 \\
Filas para carga e descarga & 2 & 5,94 & 1,50 & 1 & 5 & 6 & 7 & 7 \\
Flexibilidade & 2 & 5,74 & 1,42 & 1 & 5 & 6 & 7 & 7 \\
Greves e manifestações & & 4,73 & 2,10 & 1 & 3 & 5 & 7 & 7 \\
Lei do motorista & & 4,44 & 1,82 & 1 & 3,5 & 4 & 6 & 7 \\
Local para carga/descarga & 1 & 6,03 & 1,48 & 1 & 6 & 7 & 7 & 7 \\
Local para estacionar o veículo de carga & 1 & 5,99 & 1,59 & 1 & 6 & 7 & 7 & 7 \\
Requisitos de entrega (condições do veículo, & & & & & & & \\
equipamentos) & & 4,98 & 1,82 & 1 & 4 & 5 & 7 & 7 \\
Requisitos referentes ao atendimento & & & & & & & \\
(ajudante, SAC...) & & 5,22 & 1,90 & 1 & 4 & 6 & 7 & 7 \\
Rodízio de veículos & 2 & 5,53 & 2,11 & 1 & 4,5 & 7 & 7 & 7 \\
Tamanho do veículo & & 5,96 & 1,60 & 1 & 6 & 7 & 7 & 7 \\
Taxa de ocupação & & 5,18 & 1,81 & 1 & 4 & 6 & 7 & 7 \\
Tecnologia & & 4,86 & 1,80 & 1 & 4 & 5 & 6,5 & 7 \\
Treinamento de pessoal transporte & & 4,69 & 1,76 & 1 & 4 & 5 & 6 & 7 \\
Vias de acesso & & 4,44 & 1,76 & 1 & 3 & 5 & 6 & 7 \\
Restrição de circulação (ZMRC) & & 5,29 & 1,60 & 1 & 4 & 6 & 7 & 7 \\
Roubo de carga - zona de risco & & & 1,85 & 1 & 5 & 7 & 7 & 7 \\
\hline & & & & & & \\
\hline
\end{tabular}

Na mesma linha, pela Tabela 9, observa-se que os atributos que são quase unanimidade entre os Transportadores são: congestionamento, local para carga e descarga, roubo de carga (zona de risco) e local para estacionar o veículo. E, adicionalmente, destacam-se entre os principais problemas para essa empresa o comprometimento no recebimento, filas para carga e descarga, flexibilidade, rodízio de veículos e restrição de circulação (ZMRC).

O Quadro 14 mostra a relação entre esses principais atributos, sob o ponto de vista do Operador logístico e do Transportador. 
Quadro 14 - Atributos de distribuição urbana de carga na RMSP mais relevantes

\begin{tabular}{lcc}
\hline Atributos & Operador logístico & Transportador \\
\hline Comprometimento no recebimento & $\mathrm{X}$ & $\mathrm{X}$ \\
Congestionamento & $\mathrm{x}$ & $\mathrm{X}$ \\
Consumo sazonal (última semana do mês) & $\mathrm{x}$ & \\
Filas para carga e descarga & $\mathrm{X}$ & $\mathrm{X}$ \\
Flexibilidade & $\mathrm{X}$ & $\mathrm{X}$ \\
Local para carga e descarga & $\mathrm{x}$ & $\mathrm{X}$ \\
Local para estacionar o veículo de carga & $\mathrm{X}$ & $\mathrm{X}$ \\
Restrição de circulação (ZMRC) & $\mathrm{x}$ & $\mathrm{X}$ \\
Roubo de carga - zona de risco & & \\
\hline
\end{tabular}

Nota-se ainda, pelo Quadro 14, que “comprometimento no recebimento" (ou melhor a falta de) é percebido muito mais como problema para o Transportador do que para o Operador logístico. Talvez isso aconteça porque o Transportador é quem faz a entrega direta, que atua na última milha. Enquanto que, por outro lado, o Operador logístico valoriza mais ou denota como problema o "Consumo sazonal (concentração de entrega na última semana do mês)". Provavelmente, isto acontece porque o operador logístico necessita atender o seu cliente Embarcador em diversas regiões (não só na RMSP), com entregas a um alto número de pontos de vendas atendidos diariamente e uso de uma maior número de veículos (Tabela 7).

O Quadro 14 mostra que, exceto no caso do consumo sazonal e comprometimento no recebimento, os atributos mais relevantes são unanimidade entre os prestadores de serviços logísticos, e aqui são classificados em:

Atributos logísticos relacionados à entrega: consumo sazonal e filas para carga e descarga.

Atributos de colaboração: comprometimento no recebimento e flexibilidade para entrega em horário não programado.

Atributos regulatórios: restrição de circulação por tamanho de veículo (ZMRC), local para estacionar o veículo e local para carga e descarga

Atributos de risco: congestionamento e roubo de carga (zona de risco) 


\subsection{ANÁLISE DOS INDICADORES DE DESEMPENHO LOGÍSTICO NA RMSP.}

Neste tópico, são apresentadas as percepções dos respondentes quanto ao desempenho logístico de suas empresas na distribuição de cargas na RMSP (Bloco 3 do questionário de pesquisa).

As Tabelas 10 e 11 correspondem às medidas descritivas encontradas para os atributos, suas medidas de posição, a média, a mediana (Md), o primeiro quartil (Q1) e o terceiro quartil (Q3), e de dispersão, o desvio padrão ( $\sigma)$.

Tabela 10 - Medidas descritivas dos indicadores de desempenho logístico sob a ótica do Operador logístico

\begin{tabular}{|c|c|c|c|c|c|c|c|c|}
\hline Indicador & Destaque & Média & $\sigma$ & Mín & Q1 & $\mathrm{Md}$ & Q3 & Máx. \\
\hline OTIF & & 5,00 & 1,69 & 1 & 5 & 5 & 6 & 7 \\
\hline Avaria & & 4,88 & 1,62 & 2 & 3 & 5 & 6 & 7 \\
\hline Trajeto com menor percurso & & 4,50 & 1,74 & 1 & 3 & 5 & 6 & 7 \\
\hline Falhas na entrega & & 4,46 & 1,53 & 2 & 3 & 5 & 5,25 & 7 \\
\hline Cumprimento do prazo de entrega & 1 & 5,21 & 1,28 & 3 & 4,75 & 5,5 & 6 & 7 \\
\hline Atendimento das entregas urgentes & 1 & 5,46 & 1,50 & 1 & 5 & 6 & 6 & 7 \\
\hline Tempo de entrega na última semana do mês & 1 & 5,25 & 1,85 & 1 & 4,75 & 6 & 7 & 7 \\
\hline Devoluções & & 3,96 & 1,81 & 1 & 2 & 4 & 5 & 7 \\
\hline Roubo de carga & & 4,58 & 2,04 & 1 & 3 & 5 & 6 & 7 \\
\hline Disponibilidade de veículos & & 4,13 & 1,39 & 2 & 3 & 4 & 5 & 7 \\
\hline Extravio de carga & & 4,50 & 1,74 & 1 & 3 & 5 & 6 & 7 \\
\hline Confirmação de entrega em tempo real & & 3,96 & 1,78 & 1 & 2 & 4,5 & 5 & 7 \\
\hline
\end{tabular}

Tabela 11 - Medidas descritivas dos indicadores de desempenho logístico sob a ótica do Transportador

\begin{tabular}{|c|c|c|c|c|c|c|c|c|}
\hline Indicadores & Destaque & Média & $\sigma$ & Mín & Q1 & $\mathrm{Md}$ & Q3 & Máx. \\
\hline OTIF & & 4,79 & 1,92 & 1 & 3 & 5 & 6 & 7 \\
\hline Avaria & & 5,14 & 1,72 & 1 & 4 & 5 & 7 & 7 \\
\hline Trajeto com menor percurso & & 4,23 & 2,04 & 1 & 3 & 5 & 6 & 7 \\
\hline Falhas na entrega & & 4,60 & 1,78 & 1 & 3 & 5 & 6 & 7 \\
\hline Cumprimento do prazo de entrega & 1 & 5,24 & 1,69 & 1 & 4,5 & 6 & 6,5 & 7 \\
\hline Atendimento das entregas urgentes & 1 & 5,49 & 1,77 & 1 & 4,5 & 6 & 7 & 7 \\
\hline Tempo de entrega na última semana do mês & 1 & 5,46 & 1,77 & 1 & 5 & 6 & 7 & 7 \\
\hline Devoluções & & 4,56 & 1,78 & 1 & 3 & 5 & 6 & 7 \\
\hline Roubo de carga & & 4,47 & 2,12 & 1 & 2,5 & 5 & 6 & 7 \\
\hline Disponibilidade de veículos & & 4,29 & 1,95 & 1 & 3 & 5 & 6 & 7 \\
\hline Extravio de carga & & 5,04 & 1,85 & 1 & 3,5 & 6 & 7 & 7 \\
\hline Confirmação de entrega em tempo real & & 4,72 & 1,93 & 1 & 3 & 5 & 6,5 & 7 \\
\hline
\end{tabular}


Pelas medidas descritivas apresentadas nas Tabelas 10 e 11, nota-se que os dois agentes tem opiniões semelhantes quanto ao desempenho logístico frente aos indicadores que possuem o melhor resultado, ou seja, o cumprimento do prazo de entrega, atendimento das entregas urgentes e tempo de entrega na última semana do mês, que receberam notas médias maiores que 5 e pelo menos $75 \%$ dos respondentes atribuíram notas de 5,5 a 7 a eles.

Esse resultado é interessante uma vez que os atributos mais relevantes apresentados no Quadro 14 parecem não ter impacto na eficiência do tempo de entrega. No entanto, esta análise univariada é rasa, o que demandaria uma análise mais aprofundada por meio de estatística multivariada com todas as variáveis em conjunto, já que essas variáveis podem estar altamente correlacionadas, o que aumenta a possibilidade de ocorrência de "erro tipo 1".

Além disso, nota-se que os piores resultados de desempenho logístico são:

a) para os operadores logísticos - confirmação de entrega em tempo real, devoluções e disponibilidade de veículo;

Esses valores apresentam as menores médias e também os menores desviospadrão, ou seja, possuem menor variabilidade entre as respostas. As medidas de posição são muito semelhantes entre si.

b) para os transportadores - disponibilidade de veículo, roubo de carga e trajeto com menor percurso.

Esses valores apresentam as menores médias e, por outro lado, os maiores desvios-padrão, logo possuem maior variabilidade entre as respostas. As medidas de posição são as mesmas para os três indicadores.

Conforme análise das medidas apresentadas, os indicadores de desempenho logístico na RMSP que possuem os melhores e piores valores, são consolidados no Quadro 15. 
Quadro 15 - Indicadores logísticos - melhores e piores desempenhos

\begin{tabular}{lccc}
\hline Indicadores & Melhor & $\begin{array}{c}\text { Pior para Operador } \\
\text { Logístico }\end{array}$ & $\begin{array}{c}\text { Pior para } \\
\text { Transportador }\end{array}$ \\
\hline $\begin{array}{l}\text { Atendimento das entregas urgentes } \\
\text { Confirmação de entrega em tempo real }\end{array}$ & $\mathrm{x}$ & $\mathrm{x}$ & \\
$\begin{array}{l}\text { Cumprimento do prazo de entrega } \\
\text { Devolução de mercadoria }\end{array}$ & $\mathrm{x}$ & $\mathrm{x}$ & \\
$\begin{array}{l}\text { Disponibilidade de veículo } \\
\text { Extravio de carga }\end{array}$ & $\mathrm{x}$ & $\mathrm{x}$ \\
$\begin{array}{l}\text { Falhas na entrega } \\
\text { Roubo de carga - zona de risco }\end{array}$ & & & $\mathrm{x}$ \\
$\begin{array}{l}\text { Tempo de entrega na última semana } \\
\text { do mês }\end{array}$ & $\mathrm{x}$ & & \\
Trajeto com menor percurso & $\mathrm{x}$ & & $\mathrm{x}$ \\
\hline
\end{tabular}

O Quadro 15 revela alguns resultados interessantes. Primeiro, o Operador logístico parece ter dificuldade de lidar com "confirmação de entrega em tempo real" e "devolução de mercadorias" mais do que o Transportador. Ou seja, esse fato confirma a dificuldade do Operador logístico atender à diversidade de clientes, destinatários e às diversas regiões. Por outro lado, o Transportador revela pior desempenho quanto ao "roubo de carga" e "trajeto com menor percurso". Quanto ao roubo de carga, esse resultado pode revelar a quantidade de roubo de carga dentro da RMSP, já que cerca de $97 \%$ dessas empresas atuam localmente.

Por outro lado, é estranho o pior desempenho quanto ao trajeto, pois espera-se que os Transportadores conheçam bem os locais de entrega, as regras e dificuldades encontradas para estacionar e descarregar as cargas. Talvez isso possa revelar pouco uso de sistema de roteirização e também uso de rotas alternativas para desviar de congestionamentos. E, nesse sentido, o atributo "congestionamento" levantado como um dos principais problemas pode se revelar como um dos principais atributos que impactam o desempenho dessas empresas. Porém, são resultados que também sugerem pesquisas mais aprofundadas.

Um outro resultado interessante é que ambos os prestadores de serviço revelaram que o pior desempenho logístico está associado à "disponibilidade de veículo". Este resultado sugere que os atributos relacionados ao tempo de entrega, principalmente "tempo de entrega na última semana do mês" são os que mais impactam na disponibilidade de veículo. Ou seja, quanto maior a variabilidade da demanda e urgência, menor parece ser a disponibilidade de veiculo ou maior custo na 
contratação possa ser despendido pelos embarcadores e maior custo na manutenção, contratação e treinamento de motoristas pelos prestadores de serviço (Transportador e Operador logístico).

Nesse sentido, dada a relevância dos atributos de distribuição de carga na RMSP e a análise dos indicadores de desempenho logísticos apresentados neste tópico, pretende-se, no próximo tópico, analisar de forma global os resultados encontrados nos estudos de caso e no levantamento de dados. 


\section{ANÁLISE CRUZADA DOS RESULTADOS (ESTUDOS DE CASO E SURVEY}

Este tópico tem por objetivo analisar os resultados encontrados nos estudos de caso e no levantamento de dados (Survey), identificando pontos convergentes ou divergentes no que se refere aos papéis dos agentes, os atributos de distribuição urbana de carga e seu impacto no desempenho logístico da distribuição de carga na RMSP.

\subsection{PAPÉIS E REPONSABILIDADES DOS AGENTES (OPERADOR LOGÍSTICO E TRANSPORTADOR)}

O capital social e a localização, exceto o Operador logístico B, que é uma empresa multinacional, as demais empresas participantes dos estudos de caso, o Operador logístico A e os Transportadores A e B são empresas de capital nacional. Esse fato revela que as empresas nacionais estão cada vez mais se especializando, também, na prestação de serviço logístico e não apenas nas .

Todas as empresas do estudo de caso estão localizadas no Estado de São Paulo, na RMSP ou no interior do Estado de São Paulo (Operador logístico B) e possuem o porte similar ao encontrado no levantamento de dados, ou seja, os Operadores logísticos A e B e o Transportador B são empresas com faturamento superior a $R \$$ 2,4 milhões, exceto o Transportador A que está abaixo deste valor. Isso permitiu que as análises pudessem ser realizadas de forma comparativa.

Além disso, em relação ao perfil de entregas, o perfil do Transportador B se assemelha ao perfil dos operadores logísticos do levantamento de dados, pois atende a mais de 30 pontos de entrega ao dia e a frota contratada é superior a 50 veículos, enquanto que o perfil do Transportador A é muito similar ao encontrado no levantamento de dados das transportadoras. 
Logo, quanto ao papel desempenhado pelos agentes, os resultados do estudo de caso condizem na maioria das vezes com os resultados do levantamento de dados. Ou seja, as empresas transportadoras estão assumindo cada vez mais serviços diferenciados e, por conta disso, terceirizando parte de sua operação, enquanto os operadores procuram atender aos embarcadores oferecendo soluções logísticas diversas. No entanto, parece que os operadores também atendem a outras regiões e contratam transportadoras locais para fazer as entregas em locais distintos.

\subsection{OS ATRIBUTOS DE DISTRIBUIÇÃO URBANA DE CARGA E SEU IMPACTO NO DESEMPENHO LOGÍSTICO}

Entretanto, é interessante saber como as empresas, no geral, percebem os problemas (por meio dos atributos de carga) da RMSP. O Quadro 16 apresenta a síntese dos atributos encontrados na revisão de literatura, nos dois estudos de caso e no levantamento de dados.

Quadro 16 - Síntese dos atributos: Revisão da literatura, Estudos de caso e Levantamento de dados

\begin{tabular}{lccc}
\hline $\begin{array}{l}\text { Revisão da literatura } \\
\text { (mais citados) }\end{array}$ & $\begin{array}{c}\text { Estudo de caso A } \\
\text { (mais relevantes) }\end{array}$ & $\begin{array}{c}\text { Estudo de caso } \\
\text { B } \\
\text { (mais } \\
\text { relevantes) }\end{array}$ & $\begin{array}{c}\text { Levantamento } \\
\text { de dados } \\
\text { (mais } \\
\text { relevantes) }\end{array}$ \\
\hline $\begin{array}{l}\text { 1. Atributo logístico } \\
\text { frequência de entrega }\end{array}$ & $\mathrm{x}$ & $\mathrm{x}$ & \\
janela de entrega & $\mathrm{x}$ & $\mathrm{x}$ & $\mathrm{x}$ \\
local adequado para carga e descarga & & $\mathrm{x}$ & $\mathrm{x}$ \\
filas & $\mathrm{x}$ & $\mathrm{x}$ & \\
tempo de carga e descarga & $\mathrm{x}$ & $\mathrm{x}$ & \\
quantidade entregue ou consumo sazonal & & $\mathrm{x}$ & \\
quantidade e tipo de veículos & $\mathrm{x}$ & $\mathrm{x}$ & \\
número de entregas & $\mathrm{x}$ & $\mathrm{x}$ & \\
ocupação do veículo & $\mathrm{x}$ & & \\
custo do transporte & & & \\
distância percorrida & & &
\end{tabular}

2. Atributos de colaboração

compartilhamento de informações

$\mathrm{X}$

X 


\begin{tabular}{|c|c|c|c|}
\hline $\begin{array}{l}\text { Revisão da literatura } \\
\text { (mais citados) }\end{array}$ & $\begin{array}{l}\text { Estudo de caso } A \\
\text { (mais relevantes) }\end{array}$ & $\begin{array}{c}\text { Estudo de caso } \\
\text { B } \\
\text { (mais } \\
\text { relevantes) } \\
\end{array}$ & $\begin{array}{l}\text { Levantamento } \\
\text { de dados } \\
\text { (mais } \\
\text { relevantes) } \\
\end{array}$ \\
\hline compartilhamento de ganhos e custos & $x$ & & \\
\hline comprometimento & $x$ & $x$ & $x$ \\
\hline confiabilidade & $x$ & $x$ & \\
\hline flexibilidade & $x$ & $x$ & $x$ \\
\hline \multicolumn{4}{|l|}{ acordos logísticos } \\
\hline soluções conjuntas & $x$ & $x$ & \\
\hline \multicolumn{4}{|l|}{ 3. Atributos regulatórios } \\
\hline $\begin{array}{l}\text { restrição de circulação por horário e } \\
\text { tamanho de veículo }\end{array}$ & $x$ & $x$ & $x$ \\
\hline $\begin{array}{l}\text { regulamentação de vaga para carga e } \\
\text { descarga }\end{array}$ & $x$ & $x$ & $x$ \\
\hline \multicolumn{4}{|l|}{$\begin{array}{l}\text { 4. Atributos ambientais } \\
\text { emissão de poluentes } \\
\text { tipo de combustível }\end{array}$} \\
\hline \multicolumn{4}{|l|}{ 5. Atributos de risco } \\
\hline congestionamento & $\mathrm{x}$ & $x$ & $x$ \\
\hline roubo de carga (zona de risco) & $x$ & $x$ & $x$ \\
\hline
\end{tabular}

Por meio do Quadro 16, pode-se verificar que os atributos definidos nos estudos de caso e no levantamento de dados são encontrados na revisão de literatura.

Nota-se também que o grupo dos atributos logísticos possui maior frequência de citações na revisão de literatura e nos estudos de caso. No entanto, podemos identificar algumas convergências entre os métodos, como no caso dos atributos local adequado para carga e descarga" e "quantidade entregue ou consumo sazonal", que são atributos logísticos relacionados à entrega, e, juntamente com "filas", são os atributos logísticos mais relevantes segundo o levantamento de dados realizado nesta pesquisa.

Os atributos logísticos relacionados ao transporte como "número de entregas" (pontos de venda), ocupação de veículo e custo do transporte, não são destacados no levantamento de dados, o que reforça a preocupação dos respondentes com as dificuldades enfrentadas no momento da entrega e seu impacto no desempenho logístico. 
O grupo atributo de colaboração também possui mais citações na revisão de literatura e nos estudos de caso. No entanto, mesmo no caso em que um atributo não é apontado como relevante no levantamento de dados, ou vice versa, ele pode estar relacionado com outros atributos citados como relevante, por exemplo: soluções conjuntas para a melhoria de desempenho na entrega, que não estão identificadas como um dos atributos mais relevante no levantamento de dados, mas estão relacionadas com o nível de comprometimento na entrega que é unanimidade entre os dois métodos.

Pode-se notar que existe um alinhamento dos resultados encontrados referente aos grupos de atributos regulatórios e de risco.

No caso dos indicadores de desempenho logísticos, a dificuldade encontrada pelo operador logístico no levantamento de dados para a obtenção de "confirmação de entrega em tempo real" é também apontada pelo Operador logístico B. Outro atributo apontado como um problema no estudo de caso B pelo Cliente B1 foi em relação ao processo de devolução de mercadorias, devido a demora no recebimento de um parecer do Embarcador B1. Logo, a alternativa mais viável quando ocorre alguma divergência no recebimento da mercadoria, é o Cliente $B$ devolver toda a carga.

Outro ponto importante, é o pior desempenho apontado pelo transportador quanto ao "roubo de carga" que também foi relatado como um problema para Transportador $\mathrm{B}$, pois as cargas são de alto valor agregado e muito visadas. Por outro lado, o pior desempenho encontrado para "trajeto com o menor percurso" não foi apontado pelas empresas nos estudos de caso, pois o foco dos prestadores de serviço logísticos estudados está na efetividade da entrega.

Se for necessário para garantir a efetividade da entrega, a rota previamente estabelecida e otimizada pode ser alterada ao longo da viagem, como, por exemplo, em zona de risco ou devido ao congestionamento, que é um dos piores problemas levantados nos dois métodos, as Transportadoras A e B alteram a rota durante a viagem para garantir a totalidade das entregas. 


\section{CONCLUSÕES}

Esta dissertação teve por objetivo identificar os atributos de distribuição urbana de carga, levando-se em conta os diferentes pontos de vista dos principais responsáveis pela distribuição de carga na RMSP e que atuam no mercado varejista: Embarcador, Operador Logístico, Transportador e Cliente.

Sendo assim procurou-se atender aos seguintes objetivos:

1) Identificar os papéis fundamentais dos agentes: Embarcador, Operador Logístico, Transportador e Cliente. Este objetivo contemplou o estudo de atributos de distribuição urbana de carga, revelando que alguns desses atributos podem impactar o desempenho logístico desses agentes na distribuição de carga na RMSP.

Os papéis dos agentes e percepções quanto aos atributos da distribuição de carga na RMSP foram levantados por meio de entrevistas individuais com representantes das empresas envolvidas nos dois estudos de caso.

Pode-se observar que os prestadores de serviços logísticos, Operador logístico e Transportador, compartilham a percepção quanto a maioria dos atributos de distribuição. No entanto, os atributos ocupação do veículo e custo do transporte que são atributos logísticos relacionados ao transporte foram destacados apenas pelo Operador logístico. Esse fato pode estar relacionadas às diferenças entre os papéis desempenhados por esses dois agentes, tais como:

Operador logístico - a) Gerencia e executa a logística de carga com abordagem sistêmica e voltada a eficiência global (LIMA, 2004); b) Agente central da distribuição de carga podendo atuar na gestão de interface entre os demais agente e na busca por ações conjuntas de redução dos custos logísticos (MARRASCO, 2007).

Transportador - a) Gerenciamento e execução da movimentação de carga (STEFANSSON, 2006); b) Foco na eficiência nas operações de movimentação de carga, com destaque para a entrega na última milha (NOVAES, 2004). 
Nessa linha, o atributo de colaboração compartilhamento de ganhos e custos também foi destacado apenas pelo Operador logístico. Esse atributo requer confiança e compromisso na interação entre as empresa para que haja troca de informações e ações conjuntas de melhoria (VIEIRA; YOSHIZAKI; LEE, 2009b; VIVALDINI;PIRES, 2012).

Com relação ao papel dos demais agentes, pode-se identificar que as características e padrões de entrega são definidos pelo Cliente (BLANCO; FRANSOO, 2013) e são estabelecidos pelo Embarcador no protocolo de atendimento ao cliente (BLANCO; FRANSOO, 2013; NOVAES, 2004). Desta forma, esses agentes destacam os atributos logísticos relacionados à entrega, como o prazo de entrega do pedido, críticos para o seu desempenho logístico. Logo, o Embarcador e o Cliente demandam agilidade e regularidade na distribuição de carga por conta dos baixos níveis de estoque, aumento da frequência de entregas e pequenos volumes, decorrentes de uma política de abastecimento "Just in Time" (LIMA JUNIOR, 2005).

Nesse contexto, o Operador logístico pode vir a agregar um diferencial competitivo para a cadeia de suprimentos em termos de flexibilidade operacional, qualidade e custos logísticos (LIMA, 2004) caso possua um canal direto de comunicação com o Embarcador, que viabilize o compartilhamento da estratégia de distribuição, comercialização e atendimento ao Cliente.

Pode-se também observar nos estudos de caso que os atributos levantados na revisão de literatura foram convergentes com aqueles que as empresas adotam em suas práticas no dia a dia, com exceção dos atributos ambientais, referentes à: necessidade de uso de óleo bio combustível, controle de emissão de gases poluentes, etc., que não foram apontados como relevantes pelos agentes entrevistados no contexto do estudo. Provavelmente por não se destacarem frente aos demais atributos enfrentados pelas empresas na distribuição de carga na RMSP, ou mesmo por não serem práticas sustentáveis demandadas pelos Embarcadores ou Clientes.

2) Identificar a relevância dos atributos levantados na literatura sob a ótica dos prestadores de serviços logísticos, operador logístico e transportador, que atuam na distribuição de carga na RMSP. 
A relevância dos atributos foi identificada por meio da aplicação de questionário de pesquisa junto aos prestadores de serviços logísticos, Operador logístico e Transportador.

Com exceção dos atributos consumo sazonal (última semana do mês) e comprometimento no recebimento que foram identificados como relevantes apenas para um dos prestadores de serviços logísticos, respectivamente, para o Operador logístico e para o Transportador, os demais atributos relevantes são unanimidade entre os prestadores de serviços logísticos, sendo classificados em:

a) Atributos logísticos relacionados à entrega - consumo sazonal e filas.

b) Atributos de colaboração: comprometimento no recebimento e flexibilidade para entrega em horário não programado.

c) Atributos regulatórios: restrição de circulação por tamanho de veículo (ZMRC), local para estacionar o veículo e local para carga e descarga.

d) Atributos de risco: congestionamento e roubo de carga (zona de risco).

As exceções encontradas podem estar relacionadas às diferenças entre os papéis desempenhados pelos prestadores de serviços, que foram destacadas no tópico anterior e contempladas no levantamento de dados da pesquisa.

O Operador logístico, quando comparado com o Transportador, atende diariamente um maior numero de pontos de venda, possui um maior percentual de terceirização da frota e está localizado mais fora do que dentro da RMSP. Provavelmente, essas características de entrega e localização das empresas participantes do estudo podem contribuir para que o Operador logístico identifique o consumo sazonal como um atributo relevante para a distribuição de carga na RMSP.

Adicionalmente, o consumo sazonal demanda uma maior disponibilidade de veículos de carga na última semana do mês para atender o aumento de volume e tempo de entrega (filas).

Um fato interessante é constatado pela elevada percentagem de Transportadoras na direção de, também, terceirizar o transporte. Esse dado pode revelar grandes transportadoras que contratam transportadoras locais para fazer a entrega em lugares de difícil acesso ou que oferecem uma maior diversidade de tipos de veículos. Provavelmente essas grandes transportadoras estão assumindo o papel de 
operadores logísticos, no sentido de também oferecerem armazenagem, operações como etiquetagem, emissão de fatura, etc.

Além disso, nota-se que o Transportador, quando comparado com o Operador logístico, possui um maior percentual de entrega na RMSP. Essa característica de entrega pode contribuir para o destaque dado ao atributo de colaboração comprometimento no recebimento e a unanimidade entre os transportadores quanto aos atributos relacionados à entrega e desempenho na última milha.

Assim como nos estudos de caso, nota-se que os atributos ambientais não foram destacados pelos respondentes no levantamento de dados. Logo, percebe-se uma menor preocupação quanto ao atendimento às exigências ambientais, a sustentabilidade do transporte urbano de carga e suas externalidades negativas como, por exemplo, ruído, poluição, emissão de gases estufa e acidentes (PORTUGAL; MORGADO; LIMA JUNIOR, 2011). No entanto, países na Europa, como Bélgica, Alemanha, França (CHERRETT et al, 2012) e Inglaterra (ALLEN et al, 2000) têm demonstrado uma maior preocupação quanto a esses temas.

Adicionalmente, destacam-se as seguintes limitações encontradas ao longo desta pesquisa:

a) Tempo limitado para desenvolvimento de uma pesquisa mais aprofundada em que possam ser acompanhados os processos de negociação entre as partes envolvidas e de tomada de decisão, assim como as funções dos agentes.

b) Dificuldade de acesso aos dados secundários das empresas.

c) A análise estatística descritiva dos dados não possibilita uma análise aprofundada e a correlações entre os atributos de distribuição urbana de carga e desempenho logístico.

d) Investigação sem detalhamento aprofundado da última milha (varejo).

Como sugestões de trabalhos futuros, recomendam-se:

a) Adoção de métodos de análise estatística multivariada para melhor aprofundamento das correlação entre os atributos de distribuição e desempenho logístico, com foco na última milha;

b) Estudo das externalidades negativas da distribuição de carga na RMSP e práticas 
adotadas pelos agentes dos agentes envolvidos: setores público e privado.

As implicações para as Empresas que participaram deste estudo, estão relacionadas às:

a) Expectativas individuais dos agentes da distribuição urbana de carga: foi visto que a colaboração é essencial para que as empresas possam desenvolver ações conjuntas e diminuir a assimetria de informação nesse canal de distribuição. Portanto, mesmo que cada uma empresa seja responsável por uma parte desse processo de distribuição, a gestão coordenada entre elas é primordial. Neste sentido, o Operador logístico pode desenvolver melhor este papel por ser o elo intermediário entre esses agentes.

b) Identificação dos atributos de distribuição urbana de carga mais relevantes para cada empresa participante do estudo, o que pode contribuir para os processos de tomada de decisão à medida que podem influenciar os direcionamentos internos à empresa, por exemplo nível de atendimento das entregas no tempo acordado, taxa de ocupação de veículos e uso de sistemas de roteamento com o objetivo de evitar a utilização de rotas alternativas.

Ou seja, identificar os problemas pode ajudar às empresas a desenvolverem melhor os seus indicadores logísticos. Essa identificação pode também contribuir para o melhor relacionamento entre as empresas, ou seja, na adoção de medidas conjuntas para lidar com os desafios da região metropolitana, como compartilhamento de centro de distribuição, entregas dedicadas, etc.

Para a Academia, a contribuição é o levantamento e análise dos atributos de carga e sua classificação em grupos. Há também escassez de pesquisas no Brasil, segundo Sanches Junior (2008). Além disso, poucas pesquisa procuraram relacionar esses atributos com o desempenho logístico. 


\section{BIBLIOGRAFIA}

ALLEN, J.; Anderson, S.; Browne, M.; Jones, P. A framework for considering policies to encourage sustainable urban freight traffic and goods / service flows. London University of Westminster, 2000.

ALLEN, J., THORNE, G. AND BROWNE, M. Good Practice Guide on Urban Freight Transport. Best Urban Freight Solutions (BESTUFS), University of Westminster, 2007. 84f

ANAND, N.; Quak, H.; Duin, R. Van; Tavasszy, L. City logistics modeling efforts: Trends and gaps - A review. Procedia - Social ad Behavioral Sciences, v.39, p. $102-115,2012$.

ANDERSON, E.; DAY, S. G.; RANGAN, V. K. Strategic channel design; Sloan Management Review Association, Summer, p. 59 - 69. 1997

ANTÚN, J. P.; LOZANO, A.; ALARCÓN, R.; GRANADOS, F.;GUARNEROS, L. The physical distribution of goods in a megalopolis: Strategies for policies on the location of logistics facilities within the Central Region of Mexico. Procedia - Social and Behavioral Sciences, 2(3), 6130-6140. doi:10.1016/j.sbspro.2010.04.025, 2010.

BALLOU, R. H. Gerenciamento da cadeia de suprimentos - logística empresarial. $5^{a}$ edição. São Paulo: Bookman; 2006, 616p p.

BALLANTYNE, E. E. F.; LINDHOLM, M.; WHITEING, A. A comparative study of urban freight transport planning: addressing stakeholder needs. Journal of Transport Geography, 32, 93-101. doi:10.1016/j.jtrangeo.2013.08.013, 2013.

BENJELLOUN, A.; CRAINIC, T. G. Trends, challenges and perspectives in city logistics. Buletinul AGIR, 4p. 45 - 51, 2009.

BLANCO, E. E.; FRANSOO, J. C. Reaching 50 million nanostores: retail distribution in emerging megacities (working paper), BETA Research School, Eindhoven University of Tecnology, v. 22 Jan. 2013. 
BROWNE, M.; ALLEN, J.; NEMOTO, T.; PATIER, D.; VISSER, J. Reducing social and environmental impacts of urban freight transport: A review of some major cities. Procedia - Social and behavioral Sciences, v.39, p.19-33, jan. 2012.

CASTRO, J. T.; KUSE, Y. Impacts of large truck restrictions in freight carrier operations in metro Manila. Journal of Eastern Asia Society for Transportation Studies, v.6, pp. $2947-2962,2005$.

CASTRO, J. T.; KUSE, Y.; HYODO, T. A study on the impact and effectiveness of the truck ban scheme in metro Manila. Journal of the Eastern Asia Society for Transportation Studies, 5, 2177-2192, 2003.

CARRARA, C.M Uma aplicação do SIG para a localização e alocação de terminais logísticos em áreas urbanas congestionadas. Engenharia civil: Planejamento e Operação de sistemas de Transportes. Escola de Engenharia de São Carlos da Universidade de São Paulo, 2007. $246 f$.

CAVENAGHI, Vagner (Org.); MÀSCULO, F. S. (Org.); OLIVEIRA, V. F. (Org.). Tópicos emergentes e desafios metodológicos em engenharia de produção: casos, experiências e proposições. Vol. 4. Rio de Janeiro: ABEPRO; 2011.

CET-SP (2013). Companhia de Engenharia de Tráfego. Disponível em $<$ http://www.cetsp.com.br>. Acesso 30 jun.2013.

CHERETT, T.; ALLEN, J.; MCLEOD, F.; MAYNARD, S.; HICKFORD, A.; BROWNE, $M$. Understanding urban freight activity - key issues for freight planning. Journal of Transport Geography, 24, p. 22 - 32, 2012.

CORRÊA, H. L. Gestão de redes de suprimento: integrando cadeias de

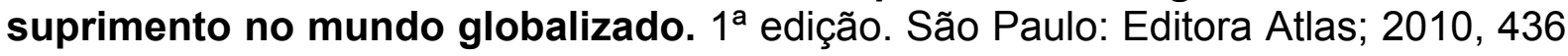
p.

CORREIA, V. D. A.; OLIVEIRA, L. K. DE; GUERRA, A. L. Economical and Environmental Analysis of na Urban Consolidation Center for Belo Horizonte City (Brazil). Procedia - Social and Behavioral Sciences, v.39, p.770-782, jan.2012.

COSTABILE, F.; ALLEGRINI, I. A new approach to link transport emissions and air quality: An intelligent transport system based on the control of traffic air pollution.

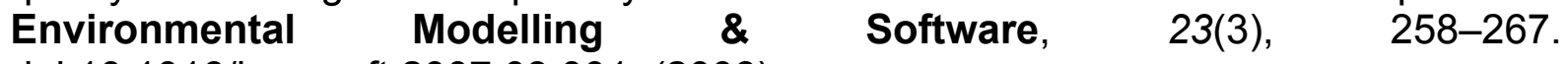
doi:10.1016/j.envsoft.2007.03.001, (2008). 
CSCMP (1998). Council Of Supply Chain Management Professionals. Disponível em $<$ http://cscmp.org/about-us/supply-chain-management-definitions>. Acesso em 02 jul.2013

DABLANC,L. Entre police at modeling: l'action publique sur le transport de merchadises um ville: Le cas des modeling de Paris et New York. Laboratoire Doctorat de Techniques, Territoires et l'Ecole nationale des ponts et epécialité: transports Sociétés modeling, 1997. 458f.

DABLANC, L. Goods transport in large European cities: Difficult to organize, difficult to modernize. Transportation Research Part A: Policy and Practices, v. 41, n.3, p. 280-285, mar. 2007.

DETRAN-SP. Estatísticas de trânsito: frota de veículos em São Paulo por tipo. Departamento Estadual de Trânsito de São Paulo. Disponível em: <https://www.detran.sp.gov.br/wps/portal/detran/odetran/estatisticasdotransito/.... Acesso em 13 jun. 2013.

DE VASCONCELLOS, E. A. Urban change, mobility and transport in São Paulo: three decades, three cities. Transport Policy, 12(2), 91-104. doi:10.1016/j.tranpol.2004.12.00, 2005.

DUTRA, N. G. D. S. O enforque de city logistics na distribuição urbana de encomendas. Tese de doutorada. Programa de Pós-Graduação em Engenharia de Produção da Universidade Federal de Santa Catarina, 2004. 229f

GATTI_JUNIOR, W.A ZMRC e o transporte urbano de cargas na cidade de São Paulo. Revista Eletrônica Gestão e Serviços, v.2, n.1, p.205-227, 2011

GOVERNO DO ESTADO DE SÃO PAULO. São Paulo em mapas. Portal do Governo do Estado de São Paulo. 2013. Disponível em <http://www.investe.sp.gov. $\mathrm{br} / \mathrm{mapa}$ /?lang=en>. Acesso em 01 jun. 2013.-

GWILLIAM, K. Cities on the move - Ten years after. Research in Transportation Economics, v. IN PRESS, p. 1-16, 2012.

HESSE, M., RODRIGUE, J.-P. The transport geography of logistics and freight distribution. Journal of Transport Geography, 12, 171-184. doi:10.1016/j.jtrangeo.2003.12.004, 2004. 
IBGE. Censo demográfico. Instituto Brasileiro de Geografia e Estatística, 2010. Disponível em: < http://www.censo2010.ibge.gov.br/sinopse/index.php?uf $=35 \&$ dados $=0>$. Acesso em 10 jun. 2013.

IBGE. Produto Interno Bruto dos Municípios - Análise dos resultados. Instituto Brasileiro de Geografia e Estatística, 2010. Disponível em <ftp://ftp. ibge.gov.br/Pib_Municipios/2010/comentarios.pdf>. Acesso em 10 jun. 2013.

IBGE. Estimativa da população dos municípios. Instituto Brasileiro de Geografia e Estatística, 2012. Disp. Em <http://saladeimprensa.ibge.gov.br/noticias?view $=$ noticia\&id=1\&busca=1\&idnoticia=2204>. Acesso em 10 jun.2013.

KANT, G.; QUAK, H.; PETEERS, R; WOENSEL, T. Urban freight transportation: challenges, failures and successes. (Unpublished Manuscript). Tilburg University, Faculty of Economics and Business Administration and Delft University of Technology, Transport and Logistics, 202, 2012.18p.

LIMA JÚNIOR, O. F. A Carga na Cidade: Hoje e Amanhã, Revista dos Transportes Públicos, São Paulo, v. 25, n. 3, p. 219-230, 2005.

LIMA, L. R. R. A evolução dos prestadores de serviços logísticos no Brasil. Dissertação de Mestrado em Engenharia de Produção, Universidade Federal de Santa Catarina, 2004. $139 \mathrm{f}$

LINDHOLM, M.; BEHRENDS, S. Challenges in urban freight transport planning - a review in the Baltic Sea Region. Journal of Transport Geography, 22, 129-136. doi:10.1016/j.jtrangeo.2012.01.001, 2012.

LJUNGBERG, D.; GEBRESENBET, G. Mapping out the potential for coordinated goods distribution in the city ceters: The case of Uppsal. International Journal of Transport Management, v.2, n. 2005, 161-172, 2005.

MARASCO, A. Third-party logistics: A literature review. International Journal of Production Economics, 113(1), 127-147. doi:10.1016/j.ijpe.2007.05.017, 2008.

METRÔ, SP. Pesquisa origem e destino 2007. Companhia do Metropolitano de São Paulo e Secretaria de Transportes Metropolitanos do Governo do Estado de São Paulo, 2008. Disponível em <http://www.metro.sp.gov.br/metro/numerospesquisa/pesquisa-origem-destino-2007.aspx. Acesso em 10 jun. 2013 
MIGUEL, P.A.C. Estudo de caso na engenharia de produção: estruturação e recomendações para sua condução. Produção, São Paulo, v. 17, n. 1, p. 216-229, Jan./Abr. 2007.

MCKINNON, A. The present and future land requirements of logistical activities. Land use Policy, v. 26, p. S293-S301, DEZ.2009.

MINISTÉRIO DAS CIDADES. Política Nacional da Mobilidade Urbana Sustentável - Princípios e Diretrizes 2004. Secretaria Nacional de Transporte e Mobilidade, 2004. 15p

MINISTÉRIO DAS CIDADES. PlanMob - Plano Diretor de Mobilidade. Secretaria Nacional de Transporte e da Mobilidade e Diretoria de Mobilidade Urbana (DEMOB), 2007. $184 p$

MOREIRA, C. M. Metodologia para obtenção de dados e informações em logística urbana - estudo de caso da região metropolitana de belo horizonte. Dissertação de Mestrado em Geotecnia e Transportes, Escola de Engenharia, Universidade Federal de Minas Gerais, 2012. 134f.

MUÑUZURI, J.; CORTÉS, P.; GUADIX, J.; ONIEVA, L. City logistics in Spain: Why it might never work. Cities, 29(2), 133-141. doi:10.1016/j.cities.2011.03.004, 2012.

NIA, S. G.; SHARIF, B.; HABIBZADEH, N.; REZVANI, M. Using the genetic algorithm for optimization of the integrated urban transportation systems. Journal of Technology Management for Growing Economies. V.2, n.1, p.103-113, 2011.

NOVAES, A. G.; CAMPOS, V. B. G.; DEXHEIMER, L.; SINAY, M. C. F. Distribuição de Carga Urbana: Componentes, Restrições e Tendências, 2004. Disponível em:<http://aquarius.ime.eb.br/ webde2/prof/vania/pubs/(16)CargaUrban.pdf>. Acesso em: 23 de maio de 2012.

OBSERVATÓRIO CIDADÃO NOSSA SÃO PAULO (2008).Apresentação. Disponível em <http://www.nossasaopaulo.org.br/observatorio/index.php?secao=apresenta>. Acesso em 20 jun.2013.

OGDEN, K. W. Urban Goods Movement: A Guide to Policy and Planning. Inglaterra: Editora Ashgate, 1992, 417p. 
OLIVEIRA, L. K. DE. Modelagem para avaliar a viabilidade de implantação de um sistema de distribuição de pequenas encomendas dentro dos conceitos de city logistics. Tese de Doutorado - PPGEP, Florianópolis, 2007.

OLIVEIRA, L. K. DE; BRAGA, A. DE S., ABREU, B. R. A. Adoption Assessment by Carriers and Retailers to Use an Urban Consolidation Center - A Case Study in Brazil. Procedia - Social and Behavioral Sciences, v. 39, p.783-795, jan.2012.

OLIVEIRA, L. K. DE ; BRAGA, A. DE S.; ABREU, B.R.A. Relevant attributes in overnight goods delivery: researches, transporters, and retailers preferences in urban distribution $12^{\text {Th }}$ WCTR. Anais...Lisbon: Portugal, 2010

OLIVEIRA, L.K. DE; NUNES, N.T.R.;NOVAES, A. G. N. assessing model for adoption of a new modeling services: $\mathrm{Na}$ application for small orders of goods distribution in Brazil. Procedia - Social and Behavioral Sciences, v.2, n.3, p.62866296, jan.2010.

ONU - HABITAT. Estado de las ciudades de América Latina y el Caribe 2012. Programa das Nações Unidas para o Assentamentos Urbanos. Rio de Janeiro: Escritório Regional para América Latina, 2012. 196p

ORGANIZAÇÃO DAS NAÇÕES UNIDAS. O Futuro que queremos. Brasil, Rio de Janeiro, 2012 ${ }^{\mathrm{a}}$. Disponível em <http://www.onu.org.br/rio20/cidades.pdf.> Acesso em: 15 jan. 2013.

PAVAN, F. M.; PIRES, S. R. I. Medição de desempenho na gestão da cadeia de suprimentos: uma proposta de indicadores de desempenho baseados no SCORE e nas dimensões competitivas da manufatura. In: XXIV Encontro Nacional de Engenharia de Produção. Florianópolis: Novodisc Mída Digital, 2004.

PIRES, S. Gestão da cadeia de suprimentos: conceitos, estratégias, práticas e casos. $2^{a}$ edição. São Paulo: Editora Atlas; 2011, 309 p.

PIRES, S.; ARAVECHIA, C. Measuring supply chain performance. In: Annual Conference of the Production and Operations Management, 12. Orlando, 2001. Disp. Em <http://www.pomsmeetings.org/Meeting2001/2001/cd/papers/pdf/Pires.pdf>. Acesso em: 03 jul. 2013.

PORTUGAL, L. DA S.; MORGADO, A. V.; LIMA JUNIOR, O. F. Location of cargo terminals in metropolitan areas of developing countries: the Brazilian case. Journal of Transport Geography, v. 19, n. 4, p. 900-910, 2011. 
PREFEITURA DO MUNICÍPIO DE SP - Mapa da Região Metropolitana de São Paulo (RMSP). Portal da Prefeitura do Município de São Paulo. 2013. Disponível em: http://www.mapas-sp.com/grande-sp.htm. Acesso em 01 jun. 2013.

SANCHEZ JUNIOR, P.F. A logística de carga urbana: uma análise da realidade brasileira. Tese de doutorado em Engenharia Civil. Faculdade de Engenharia Civil, Arquitetura e Urbanismo da Universidade Estadual de Campinas, 2008. 239.

STATHOPOULOS, A.; VALERI, E.; MARCUCCI, E. Stakeholder reactions to urban freight policy innovation. Journal of Transport Geography, 22, 34-45. doi:10.1016/j.jtrangeo.2011.11.017, 2012.

STEFANSSON, G. Collaborative logistics management and the role of third-party service providers. International Journal of Physical Distribution \& Logistics Management, 36(2), 76-92. doi:10.1108/09600030610656413, 2006.

SUSNIENÉ, D. Quality approach to the sustainability of public transport. Transport. V. 27, n. 1, p.102-110, 2012.

TACLA, D.; LIMA JUNIOR, O. F.; BOTTER, R. C A collaborative transportation proposal for urban deliveries: costs and environmental savings. Urban Transport XII. Urban Transport and the Environment in the $21^{\text {st }}$ Century. Anais... Prage: 2006

TACLA, D. Preço ou Custo? Transporte sua escolha. Revista MundoLogística, v. 17 , p. 46-51, 2010.

TANIGUCHI, E.; VAN DER HEIJDEN, R. An evaluation methodology for city logistics. Transport Reviews, 20, 1, pp 65-90, 2000.

TANIGUCHI, E.; THOMPSON, R. G. Modelling city logistics, Transportation Research, p. 45-51, 2002

TANIGUCHI, E.; THOMPSON, R. G.; YAMADA, T.; DUIN, R. City logistics - network modeling and intelligent transport systems. Oxford: Pergamon, 2001.

TANIGUCHI, E.; YAMADA, T.; OKAMOTO, M. Multi-agent modeling for evaluating dynamic vehicle routing and scheduling system. Journal of the Eastern Asia Society for Transportation Studies, v. 7, p. 933-948, 2007. 
UNITED NATIONS DEPARTMENT OF ECONOMIC AND SOCIAL AFFAIRS I POPULATION DIVISION. World Urbanization Prospects: The 2005 Revision. New York: United Nations publication, 2006. Disponível em <http://www.un.org/esa/ population/publications/WUP2005/2005WUPHighlights_Final_Report.pdf> . Acesso em 01 jun. 2013.

UNITED NATIONS DEPARTMENT OF ECONOMICS AND SOCIAL AFFAIRS I POPULATION DIVISION. World Urbanization Prospects- The 2005 Revision. New York: United Nations Publication, 2006. 210p. Disponível em http://www.un.org/esa/population/publications/WUP2005/2005WUPHighlights_Final_ Report.pdf. Acesso em 01 jun. 2013.

UNITED NATIONS DEPARTMENT OF ECONOMICS AND SOCIAL AFFAIRS / POPULATION DIVISION. World Urbanization Prospects- The 2011 Revision. New York: United Nations Publication, 2012b. 302p. Disponível em <http://esa.un.org/unup/C D -ROM/Urban-Rural-Population.htm> . Acesso em 01 jun. 2013.

VIEIRA, J. G. V. Avaliação do estado de colaboração logística entre indústria de bens de consumo e redes de varejo supermercadista. Tese de doutorado em Engenharia de Produção, Escola Politécnica, Universidade de São Paulo, 2006. 235f

VIEIRA, J. G. V.; YOSHIZAKI, H. T. Y.; CARVALHO, C. D. R. Distribuição urbana de carga na região metropolitana de São Paulo: um estudo de caso em dois operadores logísticos, In: XX Simpósio de Engenharia de Produção. Engenharia de Produção \& Objetivos de Desenvolvimento do Milênio. Bauru, 2013.

VIEIRA, J. G. V.; YOSHIZAKI, H. T. Y.; LUSTOSA, L. Os efeitos da colaboração na transação entre fornecedor e o supermercado: um estudo exploratório, Produto \& Produção, Outubro, v. 11, n. 3, p. 69-86, 2010.

VIEIRA, J. G. V.; YOSHIZAKI, H. T. Y.; HO, L. L. Um estudo sobre colaboração logística entre fornecedores de bens de consumo e redes de varejo supermercadista, Gestão e Produção, Dezembro, v. 16, n. 4, p. 556-570, 2009a .

VIEIRA, J. G. V.; YOSHIZAKI, H. T. Y.; HO, L. L. Collaboration intensity in the Brazilian supermarket retail chain, Supply Chain Management: An International Journal, v. 1, pp. 11-21, 2009b.

VIVALDINI, M.; PIRES, S. R. I. Gestão da demanda, colaboração e CPFR (Collaborative Planning, Forecasting, and Replenishment): um estudo em empresas de alimentação, Sistema e Gestão Revista Eletrônica, v.7, pp. 312-323, 2012 
YIN, R. K. Estudo de caso - planejamento e método. $2^{a}$ ed. São Paulo: Bookman, 2001. 


\section{APÊNDICE A}

\section{PROTOCOLO DE ENTREVISTA: OPERADOR LOGÍSTICO E TRANSPORTADOR}

Adaptado de Allen et al. (2000), Moreira (2012), Ljungberg e Gebresenbet (2005), Sanchez Junior (2008) e Vieira (2006)

BLOCO 1: Caracterização da empresa.

Nome da empresa:

Nome do entrevistado:

E-mail do entrevistado:

Tempo de experiência no cargo atual nessa empresa:

1. Qual o faturamento Bruto da sua empresa?

2. Qual o número de funcionários da sua empresa?

3. Quantos motoristas fazem parte do quadro de funcionários?

4. Qual o volume de carga que sua empresa recebe/coleta por dia?

5. Qual o volume de carga que sua empresa expede por dia?

6. Quais são as atividades e os serviços relacionados à distribuição de cargas que sua empresa oferece aos seus clientes?

7. Quantos clientes a empresa possui em carteira e como são classificados? Levantar $A B C$ de cliente e destinatário por volume, faturamento, setor (indústria, varejo,...), local de entrega e tipo de estabelecimento de entrega $(C D$, terminais, loja...), frequência de entrega, horário de entrega (exigência ou não de janela de entrega), tipo de carga (alimentos, bebidas, farmacêuticos, higiene e limpeza,...), formação da carga (carga fechada ou fracionada, pallets, caixas,...).

8. Quantos fornecedores a empresa possui e como são classificados? Levantar $A B C$ de fornecedores por volume, faturamento, frequência de entrega, setor (indústria, varejo,...), tipo de carga (alimentos, bebidas, farmacêuticos, higiene e limpeza,...), formação da carga (carga fechada ou fracionada, pallets, caixas,...).

9. Qual a área geográfica que a empresa atua? Como está dividida?

10. Qual o número médio de viagens semanais no último dia útil do mês com destino dentro da RMSP (informar a Origem, se dentro ou fora de SP)? 
11. Qual a quantidade média de veículos, número de viagens e entregas por veículo, por tipo de veículo por semana e no último dia útil do mês com destino dentro da RMSP?

12. Quais os produtos distribuídos na RMSP? Levantar a $A B C$ de produtos e categorias.

13. Possui sistema de informação na distribuição de carga? Quais?

14. Faz logística reversa?

BLOCO 2: Atributos relacionados a operação logística: coleta, armazenagem, consolidação e distribuição.

1. Vocês contratam terceiros para alguma das atividades logísticas que oferece aos seus clientes? Qual a participação dos terceiros no volume total distribuído?

2. Fale sobre as instalações utilizadas e localizações (próprias, terceiros, alugadas). Que atributos foram considerados na definição da estratégia de distribuição?

3. Quais são suas políticas, indicadores e metas definidas para sua operação?

4. A sua operação possui sazonalidade de entrega semanal, mensal ou anual?

5. Como está caracterizada a frota: quantidade de veículos da frota própria, terceirizada e motorista autônomo?

6. Descreva a frota de acordo com:

- Tipo de veículo.

- Idade do veículo.

- Tipo de computador de bordo.

- Tecnologia de carga/descarga.

- Tipo de combustível.

- Consumo médio de combustível por veículo.

7. Sobre as viagens, fale sobre: (avaliar no mês e na última semana do mês, caso haja sazonalidade)

- Tempo gasto nas atividades de carga e descarga.

- Duração das viagens.

- Distância percorrida (km).

- Número de paradas.

- Números de viagens por faixa de horário. 
8. Em média, qual a utilização da capacidade dos seus veículos dentro de São Paulo?

9. Qual o \% de destinatário que define agendamento e frequência de entrega? Qual a janela de entrega?

10. Qual o volume médio entregue por pedido? (avaliar no mês e na última semana do mês, caso haja sazonalidade).

11. Descreva seu fluxo do pedido. Como é feita a captação de pedidos? Qual o indicador de serviço adotado (OTIF, Case Fill,...)? No faturamento, é feita consolidação de NF por pedido?

12. Qual o prazo de entrega praticado pela sua empresa? Pratica prazo de entrega diferenciado para clientes prioritários? Possui segmentação de clientes?

13. Como é feita a conferência no recebimento e/ou expedição?

14. A sua empresa faz entregas noturnas? Qual volume total distribuído, clientes e áreas que atende? Foi uma iniciativa da sua empresa ou uma demanda do cliente? Como foi tratado o custo desta operação? Há necessidade de contratação de escolta?

15. Fale sobre as ocorrências relacionadas ao seu processo de distribuição de carga: acidente de trânsito, roubo e avaria.

16. Sua empresa faz entrega em áreas remotas? Como é a operação?

BLOCO 3: A sua empresa enfrenta os seguintes problemas na distribuição de carga? Fale sobre os seus impactos e frequências.

1. Problemas relacionados à fluidez de tráfego.

1. Atraso na entrega causado por congestionamentos.

2. Falta de sinalização e infraestrutura inadequada das vias.

3. Falta de informação sobre o trânsito nas principais vias.

4. Comportamento inadequado dos diversos motoristas e motoqueiros.

2. Problemas enfrentados durante a armazenagem, carregamento, descarregamento, transporte e estacionamento do veículo.

5. Dificuldade para encontrar local para estacionar na via.

6. Localização distante dos fornecedores e/ou clientes

7. Localização distante das principais vias.

8. Tamanho insuficiente das instalações.

9. Infraestrutura inadequada. 
10. Instalações precárias.

11. Mão de obra desqualificada

12. Falta de equipamentos adequados.

13. Sistema de controle de estoque ineficaz ou inexistente.

14. Roubo ou avaria da carga.

15. Necessidade de ajudante para entrega.

16. Falta de local adequado para carga e descarga no cliente.

17. Cliente não permite que vaga de veículo de passeio seja utilizada para carga e descarga.

18. Dificuldade em atender o prazo de entrega exigido pelo cliente.

19. Atraso na entrega.

20. Devolução de carga quando fora da janela de entrega.

21. Carga diferente do pedido.

22. Ocorrência de filas e demora no recebimento de mercadoria.

23. Falta de pessoal responsável para recebimento.

24. Problemas com greve e enchentes.

25. Poucas opções de transportadora.

26. Frete com valor elevado.

27. Grande variação no valor do frete entre as transportadoras.

28. Utilização do frete de retorno.

29. Veículo inadequado.

30. Carga não rastreada

31. Extravio de carga.

32. Avaria de carga.

33. Risco de roubo de carga.

34. Veículo de passeio estacionado na vaga exclusiva para carga e descarga.

35. Outro caminhão na área de carga e descarga.

36. Dificuldade para encontrar local para estacionar na via.

37. Falta de local exclusivo para carga e descarga na via.

38. Restrição de horário para utilização da vaga para carga, descarga e estacionamento.

39. Vaga regulamentada para carga e descarga distante do cliente.

40. Multa por estacionamento irregular

3. Utilização da frota 
41. Retorno com veículo vazio.

42. Necessidade de rastreador e seguro contra roubo.

BLOCO 4. Aspectos regulatórios.

1. Fale sobre as legislações e normas de trânsito em relação à distribuição de carga na RMSP.

2. Quais os problemas que ocorrem na sua empresa devido à aplicação das regulamentações. Você saberia dizer quais foram as medidas adotadas e os impactos no desempenho logístico? Informar:

- Aumento de custos operacionais.

- Perda de produtividade das operações de transporte.

- Dificuldade em atender os prazos de entrega.

- Necessidade de trabalho em regime de hora extra.

- Mudanças nos turnos de trabalho.

- Necessidade de transferir a carga para outros veículos.

- Roubo de carga.

- Outros.

\section{BLOCO 5. ASPECTOS DE COLABORAÇÃO.}

- Quais projetos sua empresa realiza em colaboração com os demais agentes?

- Como são compartilhados os custos e ganhos dos projetos?

\section{BLOCO 6. ASPECTOS AMBIENTAIS.}

- Fale sobre as ações e os projetos adotados por sua empresa para minimizar os impactos ambientas decorrentes da operação.

- Sua empresa mede o tipo e quantidade de poluentes emitidos e o nível de ruído nas atividades logísticas?

BLOCO 7. Oportunidades de melhoria no sistema de distribuição de cargas.

- Quais medidas você gostaria de sugerir que poderiam melhorar o transporte, armazenagem e distribuição de cargas na RMSP? 


\section{QUESTIONÁRIO DE PESQUISA}

A presente pesquisa acadêmica tem por objetivo destacar os problemas enfrentados pelas empresas no tocante à distribuição de carga na Grande São Paulo. Este trabalho está sendo desenvolvido pela estudante de mestrado Carla Carvalho ${ }^{1}$ do Programa de Pós-graduação de Engenharia em Sistemas Logísticos da USP sob a orientação do professor José Geraldo Vidal Vieira $^{2}$ e tem como objetivo gerar um documento sumarizando as percepções dos participantes, em termos agregados, sem que suas opiniões individuais ou da respectiva empresa sejam desvendadas.

\section{BLOCO 1 - CARACTERIZAÇÃO DA EMPRESA}

\begin{tabular}{|l|l|}
\hline Nome do respondente: & \\
\hline Cargo: & \\
\hline Tempo de experiência neste cargo: & \\
\hline Você é um: & Operador logístico $\quad \bigcirc$ Transportadora \\
\hline
\end{tabular}

1. Quais os principais setores de atuação da sua empresa? Pode marcar mais de uma opção.

\begin{tabular}{llllll}
\hline & Alimentício e bebidas & $\square$ & Eletro-Eletrônico e Tecnologia & Energia/Combustível \\
\hline & Automotivo e Autopeças & $\square$ & Telecomunicações & Químico \\
\hline & Vestuário e acessórios & $\square$ & Higiene Pessoal e Limpeza & Hospitalar e Fármacos \\
\hline Bazar e material escritório & $\square$ & Construção (civil, naval, etc) & Outros:
\end{tabular}

2. Capital da empresa:
$\bigcirc$ Nacional
Não nacional

3. Localização da UNIDADE onde trabalha (Cidade/Estado):

4. Número total de funcionários da EMPRESA:
Menor que 10
$\bigcirc$ De 10 a 49
$\bigcirc$ De 50 a 99
$\bigcirc$ Maior que 100

5. Faturamento bruto da EMPRESA em 2012:

$\bigcirc$ Menor que 240 mil $\bigcirc$ Entre 240 mil e 2,4 milhões

Maior que 2,4 milhões

\section{AS PERGUNTAS SEGUINTES SE REFEREM À DISTRIBUIÇÃO DE CARGA NA GRANDE SÃO PAULO}

6. Qual a porcentagem total entregas realizadas na Grande São Paulo:
$\bigcirc$ Menor que $25 \%$
Entre $25 \%$ e $49 \%$
Entre $50 \%$ e $75 \%$
Maior que $75 \%$

\footnotetext{
${ }^{1}$ Carla.carvalho@usp.br

${ }^{2}$ Jose-vidal@ufscar.br
} 


\section{BLOCO 2 - PERFIL DAS ENTREGAS NA GRANDE SÃO PAULO}

7. Quantas entregas (embarques), em média, são realizadas diariamente na RMSP?
Menos que 4
De 4 a 10
De 11 a 29
Mais que 30

8. Quantos destinatários são abastecidos, em média, diariamente (RMSP):

9. Qual o PERCENTUAL do volume diário embarcado por veículo (RMSP)?

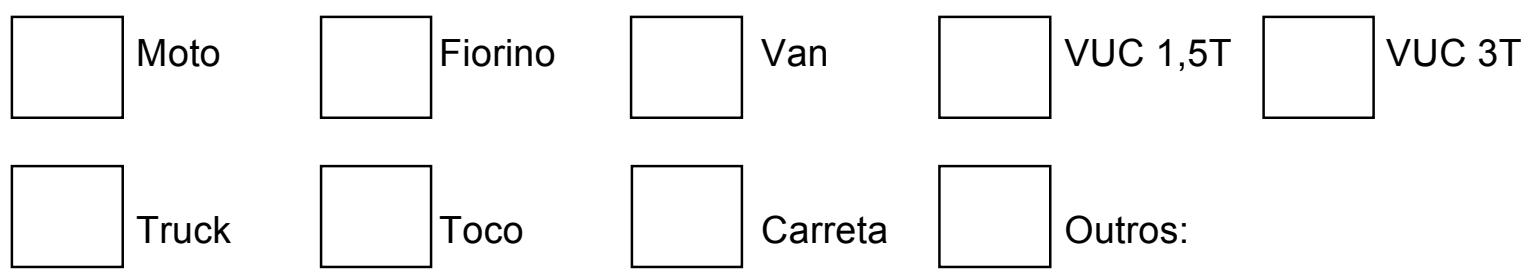

10. Qual a porcentagem de entrega direta à loja (RMSP):
○\%
Até $25 \%$
Entre $25 \%$ e $50 \%$
Maior que $50 \%$

11. Qual a porcentagem de veículos terceirizados:
$0 \%$
Até $25 \%$
Entre $25 \%$ e $50 \%$
Maior que $50 \%$

\section{BLOCO 3 - DESEMPENHO LOGÍSTICO NA GRANDE SÃO PAULO}

12. Marque o GRAU de concordância quanto ao seu desempenho logístico referente à distribuição de mercadorias na Grande São Paulo (1 - Discordo totalmente, 2 Discordo em grande parte, 3 - Discordo em parte; 4 - Neutro, 5 - Concordo em parte; 6 - Concordo em grande parte, 7 - Concordo totalmente).

DISCORDO CONCORDO

\begin{tabular}{|l|l|l|l|l|l|l|l|}
\hline As entregas são sempre pontuais e na data acordada & 1 & 2 & 3 & 4 & 5 & 6 & 7 \\
\hline Raramente ocorrem avarias & 1 & 2 & 3 & 4 & 5 & 6 & 7 \\
\hline Os trajetos são sempre feitos com a menor distância percorrida & 1 & 2 & 3 & 4 & 5 & 6 & 7 \\
\hline As entregas são sempre sem erro & 1 & 2 & 3 & 4 & 5 & 6 & 7 \\
\hline O prazo de entrega acordado é sempre cumprido & 1 & 2 & 3 & 4 & 5 & 6 & 7 \\
\hline As entregas urgentes são sempre no prazo estabelecido & 1 & 2 & 3 & 4 & 5 & 6 & 7 \\
\hline O tempo de entrega na última semana do mês é muito maior & 1 & 2 & 3 & 4 & 5 & 6 & 7 \\
\hline Raramente ocorre devolução de mercadoria & 1 & 2 & 3 & 4 & 5 & 6 & 7 \\
\hline Raramente ocorre roubo de carga & 1 & 2 & 3 & 4 & 5 & 6 & 7 \\
\hline Sempre há disponibilidade de veículo & 1 & 2 & 3 & 4 & 5 & 6 & 7 \\
\hline Raramente ocorre extravio de carga & 1 & 2 & 3 & 4 & 5 & 6 & 7 \\
\hline Sempre é feita a confirmação de entrega em tempo real & 1 & 2 & 3 & 4 & 5 & 6 & 7 \\
\hline
\end{tabular}




\section{BLOCO 4 - PROBLEMAS NA DISTRIBUIÇÃO DE CARGA NA GRANDE SÃO PAULO}

13. Coloque o seu GRAU de concordância para os problemas seguintes referentes à distribuição de mercadorias na Grande São Paulo (1 - Discordo totalmente, 2 Discordo em grande parte, 3 - Discordo em parte; 4 - Neutro, 5 - Concordo em parte; 6 - Concordo em grande parte, 7 - Concordo totalmente).

DISCORDO CONCORDO

\begin{tabular}{|c|c|c|c|c|c|c|c|}
\hline Tráfego intenso/congestionamento & 1 & 2 & 3 & 4 & 5 & 6 & 7 \\
\hline Ausência de local adequado para carga/descarga & 1 & 2 & 3 & 4 & 5 & 6 & 7 \\
\hline Falta de compartilhamento de informação com destinatário final & 1 & 2 & 3 & 4 & 5 & 6 & 7 \\
\hline Falta de compartilhamento de informação com o cliente & 1 & 2 & 3 & 4 & 5 & 6 & 7 \\
\hline Pouca flexibilidade do destinatário para entrega em outro horário & 1 & 2 & 3 & 4 & 5 & 6 & 7 \\
\hline Via de acesso estreita para entrega & 1 & 2 & 3 & 4 & 5 & 6 & 7 \\
\hline Zona máxima de restrição & 1 & 2 & 3 & 4 & 5 & 6 & 7 \\
\hline Rodízio para circulação de veículos por placa & 1 & 2 & 3 & 4 & 5 & 6 & 7 \\
\hline Áreas com falta de segurança/risco & 1 & 2 & 3 & 4 & 5 & 6 & 7 \\
\hline Falta de treinamento de motorista e encarregado & 1 & 2 & 3 & 4 & 5 & 6 & 7 \\
\hline Lei do motorista & 1 & 2 & 3 & 4 & 5 & 6 & 7 \\
\hline Manifestações e greves públicas & 1 & 2 & 3 & 4 & 5 & 6 & 7 \\
\hline Enchente & 1 & 2 & 3 & 4 & 5 & 6 & 7 \\
\hline Ausência de local adequado para estacionamento & 1 & 2 & 3 & 4 & 5 & 6 & 7 \\
\hline Falta de comprometimento no recebimento da mercadoria & 1 & 2 & 3 & 4 & 5 & 6 & 7 \\
\hline Falta de tecnologia de informação para troca de dados & 1 & 2 & 3 & 4 & 5 & 6 & 7 \\
\hline Grandes filas para carga e descarga & 1 & 2 & 3 & 4 & 5 & 6 & 7 \\
\hline Acúmulo de entregas na última semana do mês & 1 & 2 & 3 & 4 & 5 & 6 & 7 \\
\hline Atendimento ao controle de emissão de gases poluentes & 1 & 2 & 3 & 4 & 5 & 6 & 7 \\
\hline Atendimento as metas de redução de emissão de $\mathrm{CO} 2$ & 1 & 2 & 3 & 4 & 5 & 6 & 7 \\
\hline Adequação ao uso de biocombustível & 1 & 2 & 3 & 4 & 5 & 6 & 7 \\
\hline Baixa ocupação do veículo & 1 & 2 & 3 & 4 & 5 & 6 & 7 \\
\hline Falta de confiança no recebimento da mercadoria & 1 & 2 & 3 & 4 & 5 & 6 & 7 \\
\hline Exigência quanto ao tamanho do veículo utilizado na entrega & 1 & 2 & 3 & 4 & 5 & 6 & 7 \\
\hline Exigência para a entrega (condições do veículo/equipamentos) & 1 & 2 & 3 & 4 & 5 & 6 & 7 \\
\hline Exigências de equipes dedicadas ao atendimento (ajudante, SAC, etc.) & 1 & 2 & 3 & 4 & 5 & 6 & 7 \\
\hline Necessidade de entregas noturnas & 1 & 2 & 3 & 4 & 5 & 6 & 7 \\
\hline
\end{tabular}

